\title{
Expression and functional analyses of murine Pelota (Pelo) gene
}

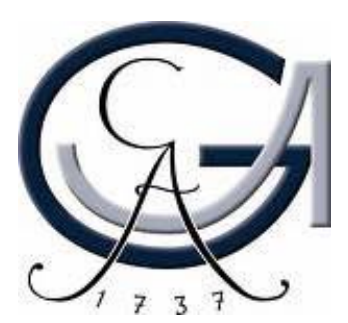

\author{
Dissertation \\ zur Erlangung des Doktorgrades \\ der Mathematisch-Naturwissenschaftlichen Fakultäten \\ der Georg-August-Universität zu Göttingen
}

\author{
vorgelegt von \\ Byambajav Buyandelger \\ aus Zavkhan, der Mongolei
}

Göttingen, December 2006 
D7

Referent: $\quad$ Prof. Dr. W. Engel

Korreferent: $\quad$ PD Dr. S. Hoyer-Fender

Tag der mündlichen Prüfungen: 
CONTENTS Page

CONTENTS I I

ABBREVIATIONS VI

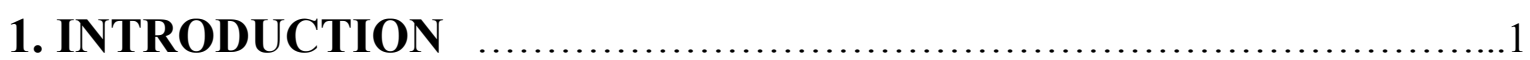

1.1 Pelota $($ Pelo $)$ is an evolutionarily conserved gene...................................................... 1

1.2 Expression and function of Pelota gene.................................................................... 4

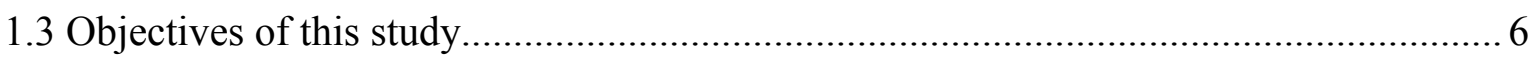

2. MATERIALS AND METHODS …..................................................... 7

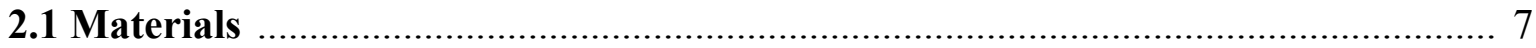

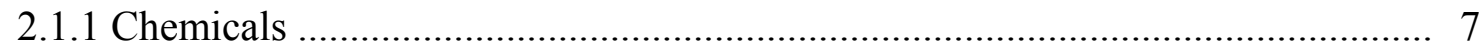

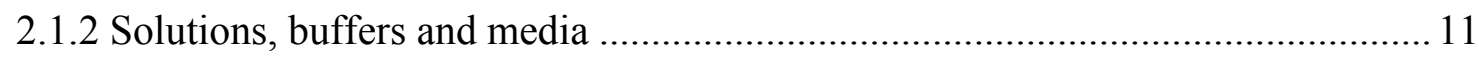

2.1.2.1 Agarose gel electrophoresis ............................................................... 11

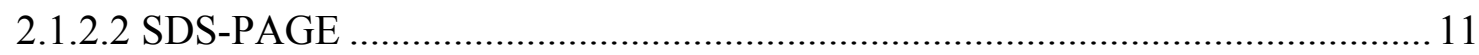

2.1.2.3 Frequently used buffers and solutions ....................................................... 12

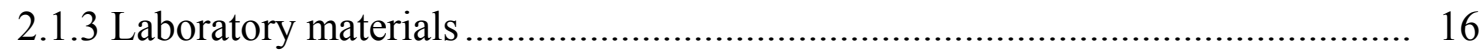

2.1.4 Sterilisation of solutions and equipment........................................................ 17

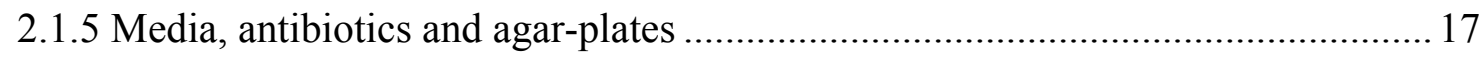



2.1.5.2 Media for cell and embryo culture........................................................ 18

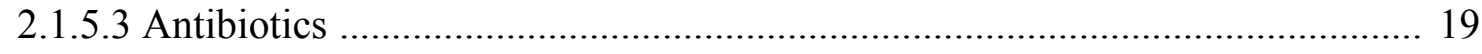

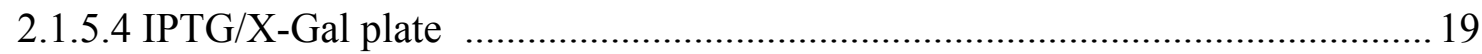

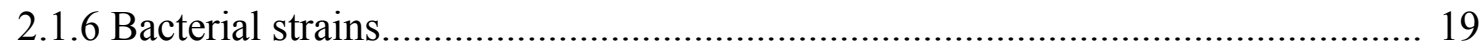

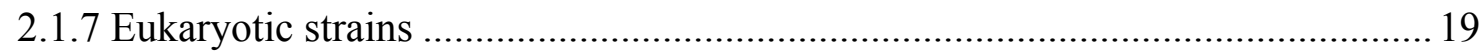

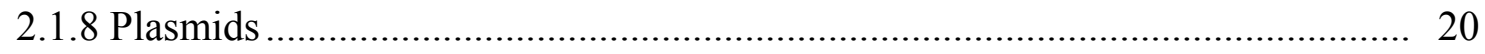

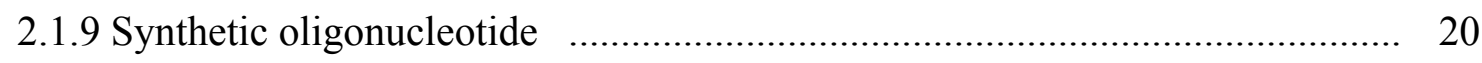

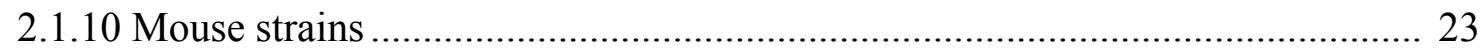

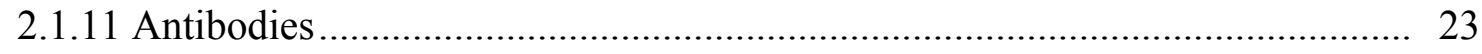

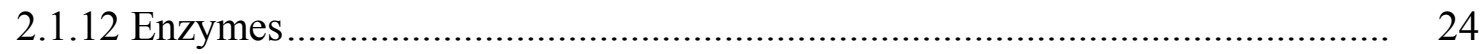




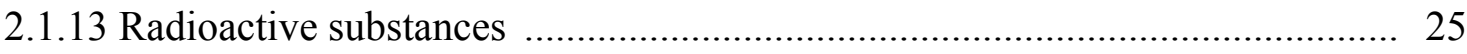

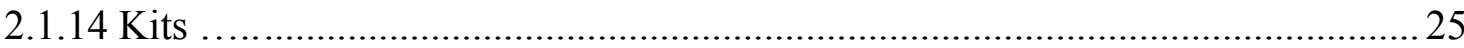

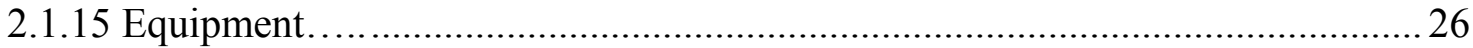

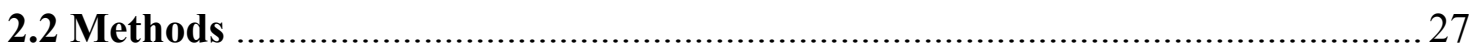

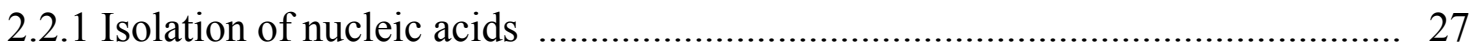

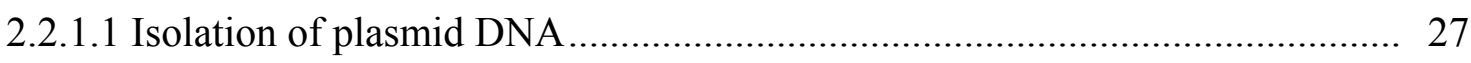

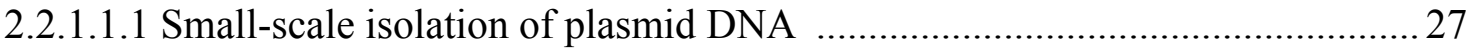

2.2.1.1.2 Large-scale preparation of Endotoxin free plasmid DNA ............................28

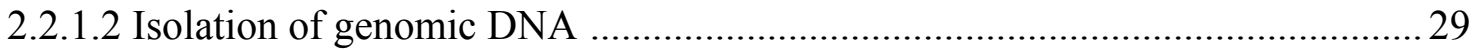

2.2.1.2.1 Isolation of genomic DNA from tissue samples with isopropanol.................29

2.2.1.2.2 Isolation of genomic DNA from cultured cells ..........................................29

2.2.1.3 Isolation of total RNA from tissue samples and cultured cells........................29

2.2.2 Determination of nucleic acid concentration ...................................................... 30

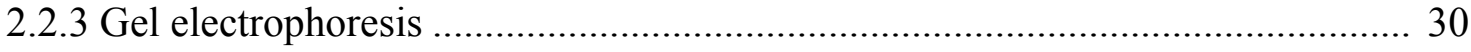

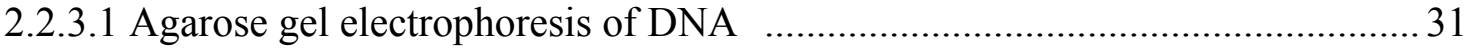

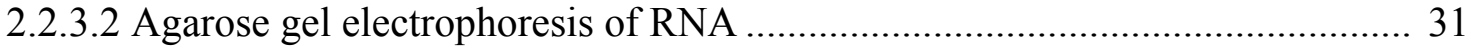

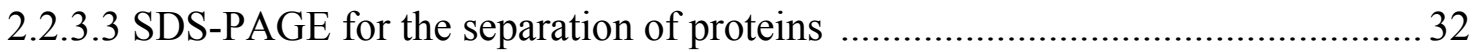

2.2.4 Purification of DNA fragments from agarose gel.............................................. 32

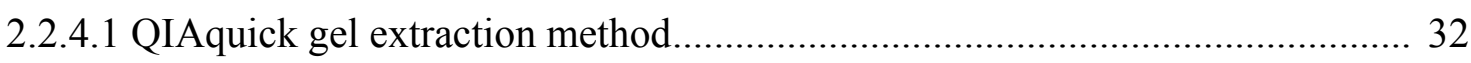

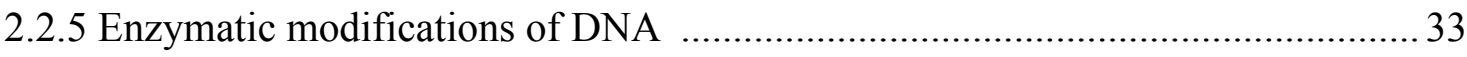

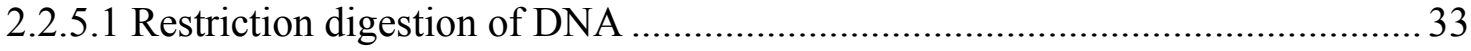

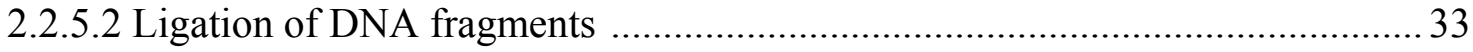

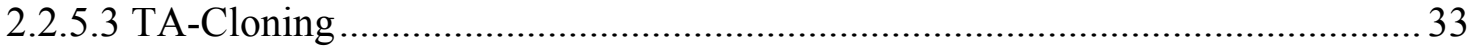

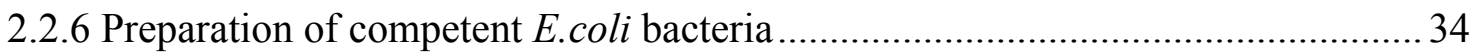

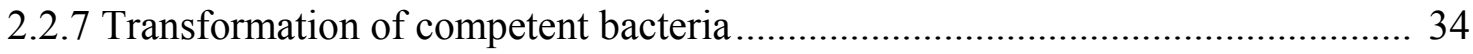

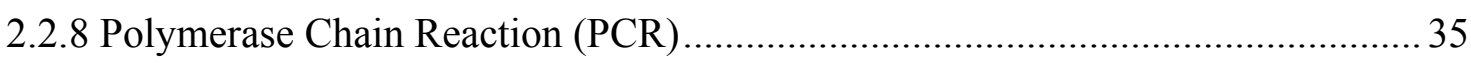

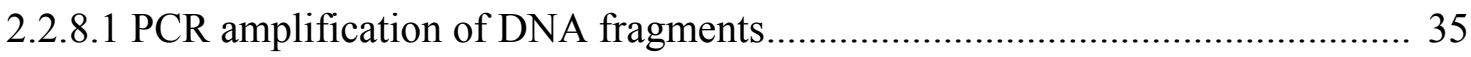

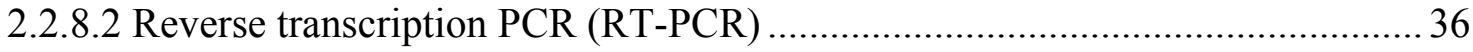

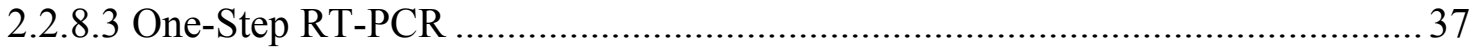

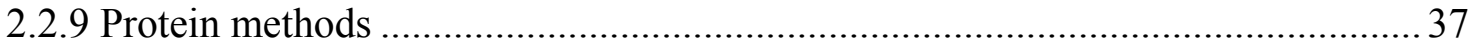

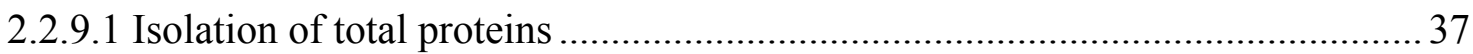

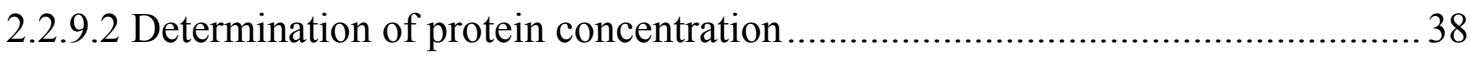

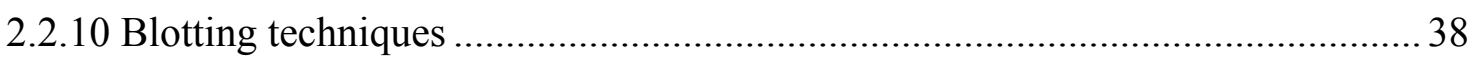


2.2.10.1 Southern blotting of DNA onto nitrocellulose filter................................... 38

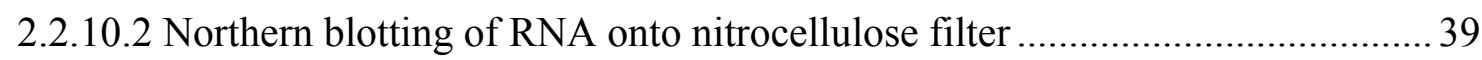

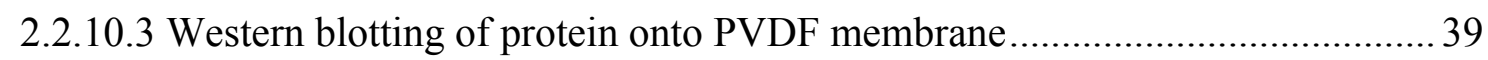

2.2.11 "Random Prime" method for generation of ${ }^{32} \mathrm{P}$ labeled DNA.......................... 40

2.2.12 Non-radioactive dye terminator cycle sequencing ...................................... 41

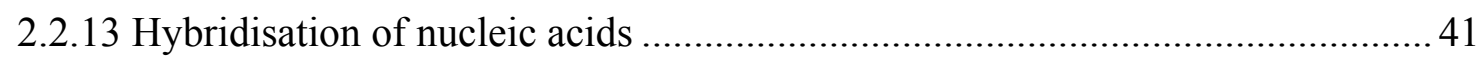

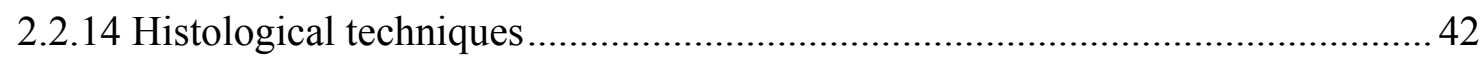

2.2.14.1 Tissue preparation for paraffin embedding ............................................... 42

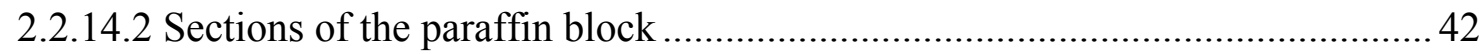

2.2.14.3 Immunofluorescence staining of mouse tissues......................................... 43

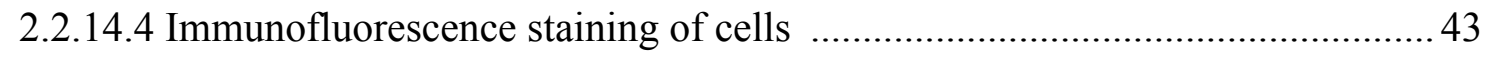

2.2.14.5 Hematoxylin-eosin (H\&E) staining of the histological sections .................... 44

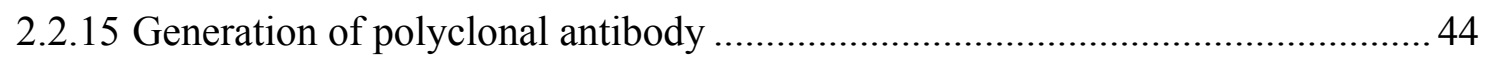

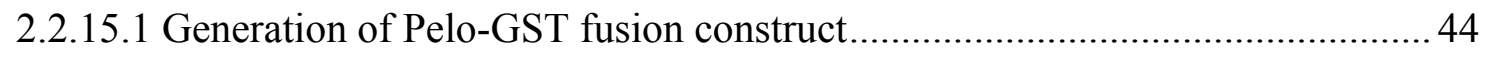

2.2.15.2 Expression of recombinant proteins in the $\mathrm{pET}$ vector................................ 45

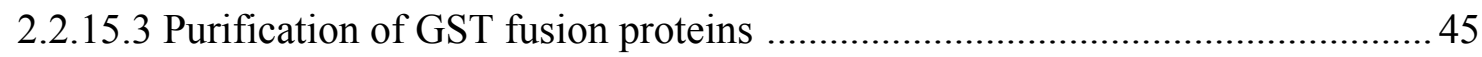

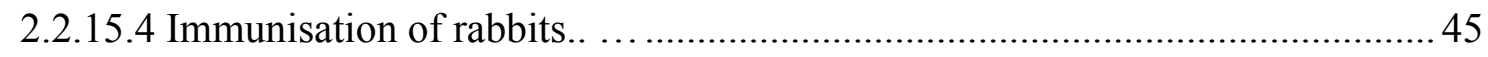

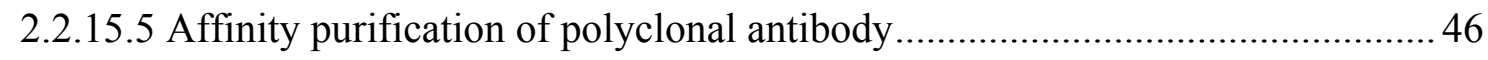

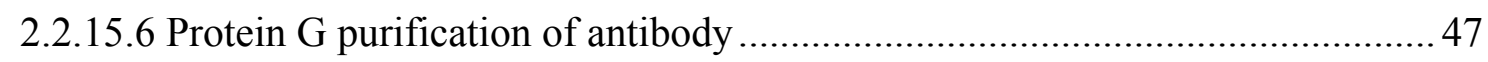

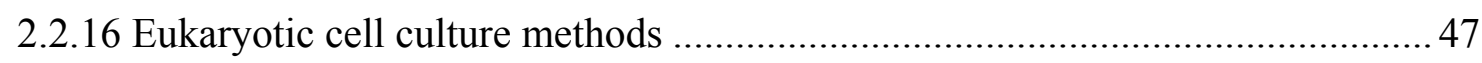

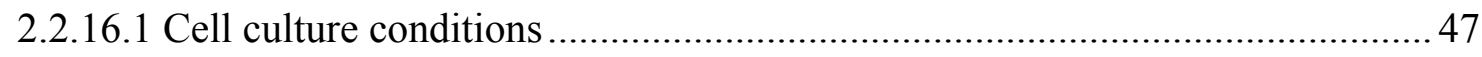

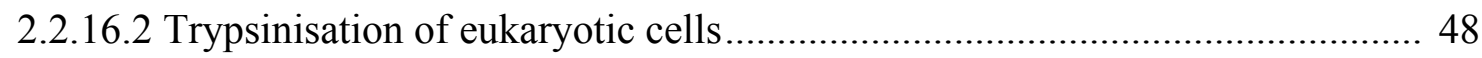

2.2.16.3 Cryopreservation and thawing of eukaryotic cells .................................... 48

2.2.16.4 Isolation and handling of primary mouse embryonic fibroblasts ................... 48

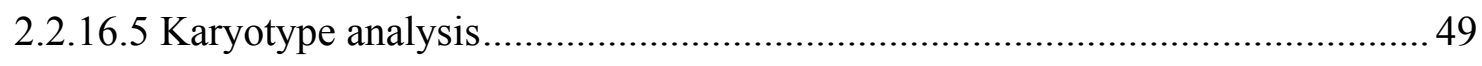

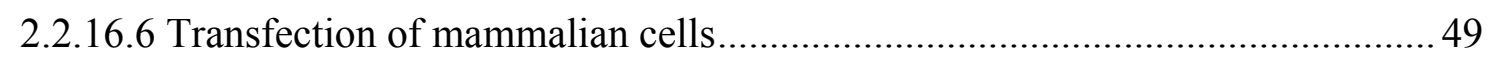

2.2.17 Techniques for production of targeted mutant mice....................................... 50

2.2.17.1 Production of targeted embryonic stem cell clones .....................................50

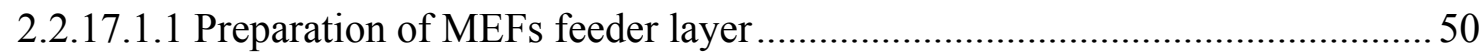

2.2.17.1.2 Growth of ES cells on feeder layer....................................................... 51

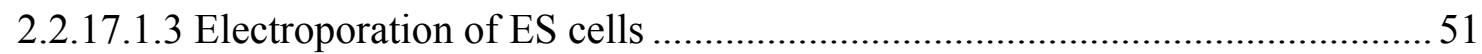

2.2.17.1.4 Growing ES cells for Southern blot analysis ............................................52

2.2.17.2 Production of chimeras by injection of ES cells into blastocysts .................... 52 


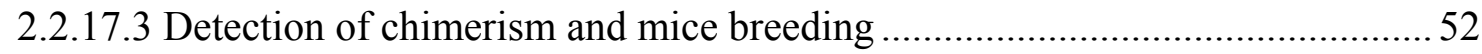

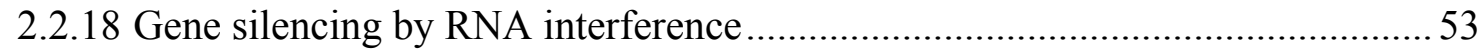

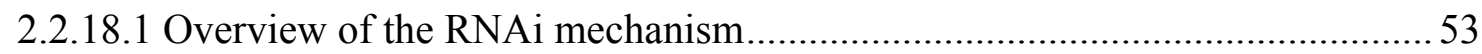



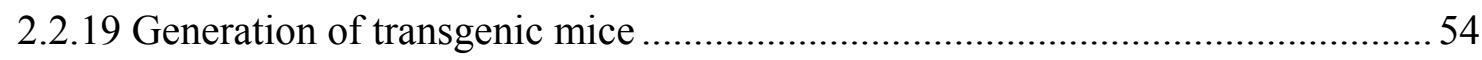

2.2.19.1 Preparation of DNA for pronuclear microinjection..................................... 54

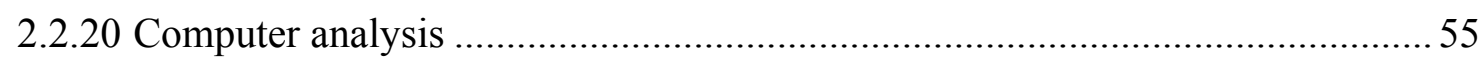

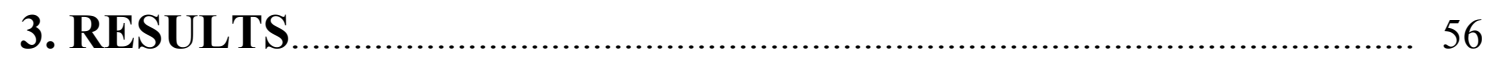

3.1 Generation of polyclonal antibody against Pelota and expression analysis ............56

3.1.1 Generation and purification of polyclonal anti-Pelo antibody ............................ 56

3.1.2 Cellular localisation of Pelo protein in mouse embryonic fibroblasts ................ 58

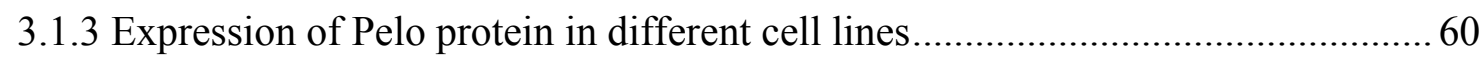

3.1.4 Expression of Pelo protein in mouse tissues..................................................... 61

3.1.5 Expression of Pelo protein during testicular development and

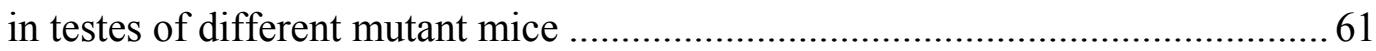

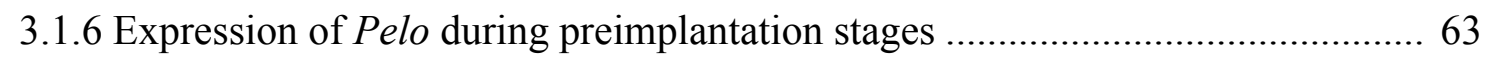

3.1.7 Expression and localisation of Pelo protein in testicular cell fractions ................63

3.2 Knockdown of Pelota gene using inducible siRNA system in vitro........................65

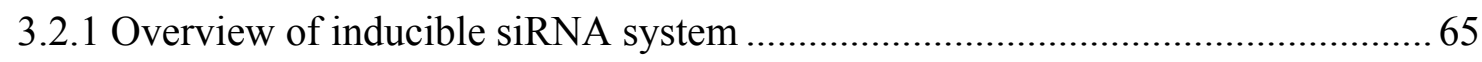

3.2.2 Selection of siRNA sequences for specific targeting of Pelo mRNA ..................67

3.2.3 Efficiency of Pelo-siRNA to knockdown the Pelo transcript ............................ 71

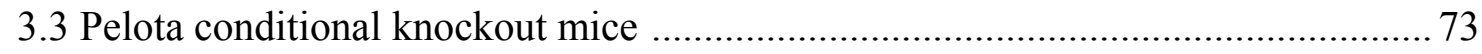

3.3.1.1 Generation of conditional knockout targeting construct............................... 73

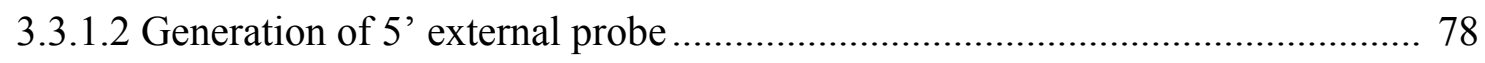

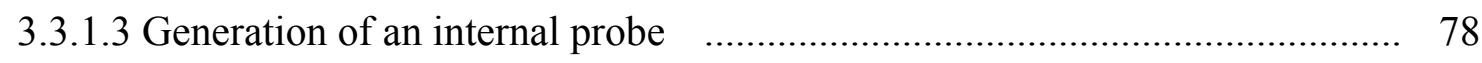

3.3.1.4 Electroporation and screening of R1 ES cells for homologous recombination. 81

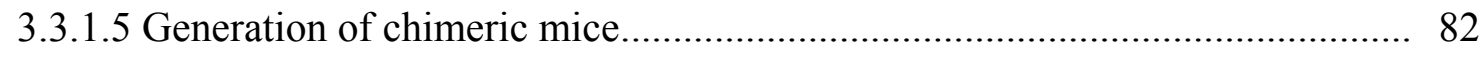

3.3.2 Generation of non-inducible conditional knockout mice ............................... 84

3.3.2.1 Breeding strategy to generate Peloflox/- EIIaCre double transgenic mice ............ 84

3.3.3 Generation of Pelota inducible conditional knockout mice................................. 89

3.3.3.1 Breeding strategy to generate Pelo ${ }^{\text {flox/- }} \mathrm{CreER}^{T}$ double transgenic mice ............ 89

3.3.3.2 Fertility test of the TAM-treated mice............................................................ 89 
3.3.3.3 Histological analysis of TAM-treated mice 91

3.3.3.4 Immunohistochemical analysis of testes sections of TAM-treated Pelo ${ }^{\text {flox/- }}$ CreER ${ }^{T}$ mice 93

3.3.3.5 The efficiency of TAM-induced recombination of Pelo ${ }^{\text {flox }}$ by $\mathrm{CreER}^{T}$............ 94

3.3.3.6 Protein study in the testes of TAM-treated Pelo ${ }^{\text {flox/- }} \mathrm{CreER}^{T}$ mice ..................... 95

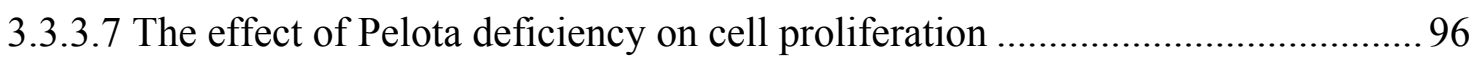

3.3.3.8 Expression analysis of Pelota in OHT-treated fibroblasts at protein level....... 98

3.3.3.9 Proliferation assay of OHT-treated fibroblasts ................................................ 98

3.3.3.10 Karyotype analysis of OHT-treated fibroblasts ......................................... 99

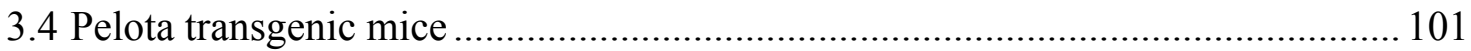

3.4.1 Generation of $h E F-P e l o$ transgenic construct and purification .......................... 101

3.4.1.1 Generation and breeding of transgenic mice ............................................ 102

3.4.1.2 Expression analysis of $h E F-P e l o$ transgenic mice ....................................... 103

3.4.2 Generation of $h U B$-Pelo transgenic construct and purification ....................... 104



3.4.2.2 Expression studies of $h U B-P e l o$ transgenic mice ....................................... 106

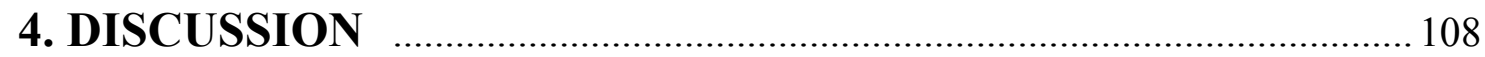

4.1 Expression pattern and subcellular localisation of Pelota ................................... 108

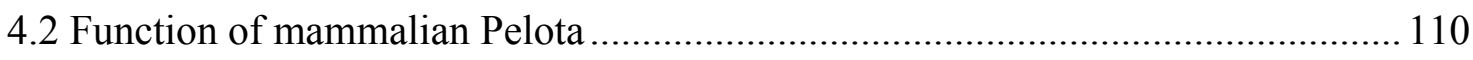

4.3 Knockdown of Pelota using inducible siRNAs system .................................... 110

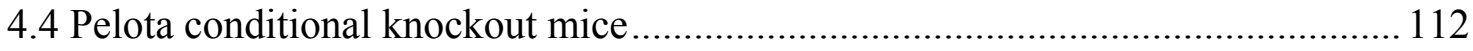

4.5 The effect of Pelota deficiency on cell proliferation .......................................... 114

4.6 Drosophila Pelota controls self renewal of germline stem cells ......................... 115

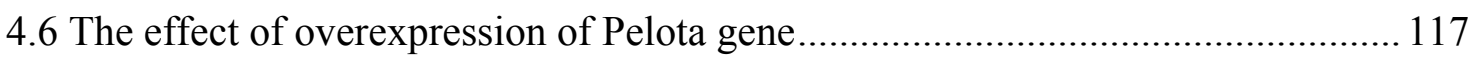

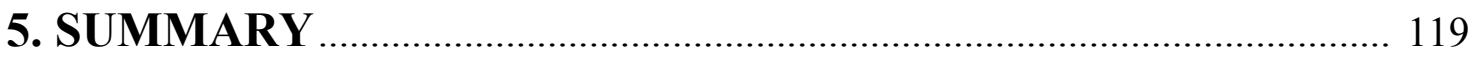

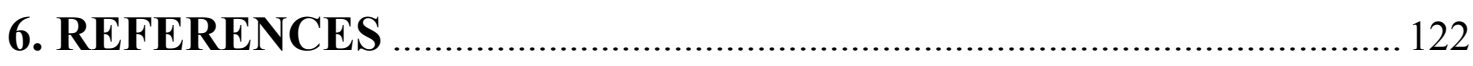

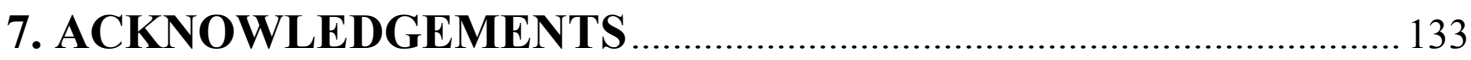

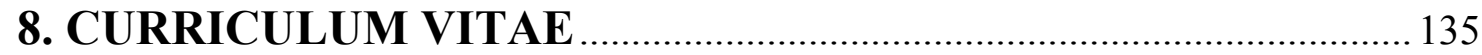


ABBREVIATIONS

ABI

AP

ATP

BCIP

bp

BSA

${ }^{\circ} \mathrm{C}$

cDNA

dATP

$\mathrm{dH}_{2} \mathrm{O}$

DAPI

$\mathrm{dCTP}$

DMEM

DEPC

DNA

DNAse

dNTP

DOX

dpc

dT

DTT

EDTA

EGFP

ES

$\mathrm{EtBr}$

FCS

g

GSC

HBSS

HE

HEPES

$\operatorname{hr}(\mathrm{s})$
Applied Biosystem Instrument

Alkaline Phosphatase

Adenosinetriphosphate

1-bromo-3-chloropropane

base pair

Bovine Serum Albumin

Degree Celsius

complementary DNA

desoxyriboadenosintriphosphate

distilled water

Diamidino-2-phenylindole dihydrochloride

Desoxyribocytosinetriphosphate

Dulbecco’s Modified Eagle Medium

Diethylpyrocarbonate

Deoxyribonucleic acid

Deoxyribonuclease

deoxynucleotidetriphosphate

Doxycycline

day post coitum

deoxythymidinate

Dithiothreitol

Ethylene Diamine Tetraacetic Acid

Enhanced Green Fluorescence Protein

Embryonic Stem

Ethidium Bromide

Fetal Calf Serum

gravity

Germline Stem Cell

Hanks’ Balanced Salt Solution

Heterozygote

N-(-hydroxymethyl)piperazin,N'-3-propanesulfoneacid hour(s) 


\begin{tabular}{|c|c|}
\hline ICM & Inner Cell Mass \\
\hline IPTG & Isopropyl- $\beta$-thiogalactopyranoside \\
\hline $\mathrm{kb}$ & kilobase \\
\hline $\mathrm{kDa}$ & Kilodalton \\
\hline LIF & Leukaemia Inhibitory Factor \\
\hline MEFs & Mouse Embryonic Fibroblasts \\
\hline mRNA & messenger Ribonucleic acid \\
\hline $\mathrm{mg}$ & milligram \\
\hline $\mathrm{ml}$ & milliliter \\
\hline $\mathrm{mM}$ & millimolar \\
\hline$\mu 1$ & microlitre \\
\hline$\mu \mathrm{m}$ & micrometre \\
\hline$\mu \mathrm{M}$ & micromolar \\
\hline $\min$ & minute \\
\hline $\mathrm{NaAc}$ & Sodium acetate \\
\hline NBT & Nitro-blue tetrazolium \\
\hline NCBI & National Center for Biotechnology Information \\
\hline Neo & Neomycin \\
\hline ng & nanogram \\
\hline NLS & Nuclear Localisation Signal \\
\hline $\mathrm{nm}$ & nanometer \\
\hline OD & Optimal Density \\
\hline OHT & 4-hydroxytamoxifen \\
\hline ORF & Open Reading Frame \\
\hline RT & Room Temperature \\
\hline TAM & Tamoxifen \\
\hline Tet & Tetracycline \\
\hline UV & Ultraviolet Light \\
\hline WT & Wildtype \\
\hline
\end{tabular}




\section{Symbols of nucleic acids}
A
Adenosine
C
Cystidine
G
Guanosine
$\mathrm{T}$
Thymidine
$\mathrm{U}$
Uridine

\section{Symbols of amino acids}

\begin{tabular}{|c|c|c|}
\hline $\mathrm{A}$ & Ala & Alanine \\
\hline $\mathrm{B}$ & Asx & Asparagine or Aspartic acid \\
\hline $\mathrm{C}$ & Cys & Cysteine \\
\hline $\mathrm{D}$ & Asp & Aspartic acid \\
\hline $\mathrm{E}$ & Glu & Glutamic acid \\
\hline $\mathrm{F}$ & Phe & Phenylalanine \\
\hline G & Gly & Glycine \\
\hline $\mathrm{H}$ & His & Histidine \\
\hline I & Ile & Isoleucine \\
\hline $\mathrm{K}$ & Lys & Lysine \\
\hline $\mathrm{L}$ & Leu & Leucine \\
\hline M & Met & Methionine \\
\hline $\mathrm{N}$ & Asn & Asparagine \\
\hline $\mathrm{P}$ & Pro & Proline \\
\hline Q & Gln & Glutamine \\
\hline $\mathrm{R}$ & Arg & Arginine \\
\hline $\mathrm{S}$ & Ser & Serine \\
\hline $\mathrm{T}$ & Thr & Threonine \\
\hline $\mathrm{V}$ & Val & Valine \\
\hline W & $\operatorname{Trp}$ & Tryptophan \\
\hline $\mathrm{Y}$ & Tyr & Tyrosine \\
\hline 7 & Glx & Glutamine or Glutamic acid \\
\hline
\end{tabular}




\section{INTRODUCTION}

\subsection{Pelota (Pelo) is an evolutionarily conserved gene}

The Pelo gene was originally identified in a mutagenesis screen of male fertility in Drosophila (Castrillon et al., 1993). The Pelo gene has been then isolated and characterized in archaebacteria Methanococcus jannaschii (Bult et al., 1996), Sulfolobus solfataricus (Ragan et al., 1996), in yeast Saccharomyces cerevisiae (Davis and Engebrecht, 1998), in worm Caenorhabditis elegans (Gen Bank, Accession No.Z36238), in plant Arabidopsis thaliana (Gen Bank, Accession No.T20628), in human (Shamsadin et al., 2000) and in mouse (Shamsadin et al., 2002). The comparison of the predicted amino acid and nucleotide sequences of Pelo from twelve species reveals a high level of sequence conservation (Table 1.1). The protein sequence identity ranges from $55 \%$ between mouse and S.cerevisiae and $96 \%$ between mouse and human (Table 1.1). The encoded protein ranges between 378 and 432 amino acids.

The PROSITE protein motif library fails to reveal major structural motifs indicating a particular biological function of the Pelo protein. However, numerous putative phosphorylation motifs were detected, spread across the length of the predicted protein. This includes motifs for protein kinase $\mathrm{C}$, casein kinase II and tyrosine kinase phosphorylation sites. Furthermore, two N-glycosylation and three N-myristoylation sites were detected in the mammalian protein. It is currently unknown which of these putative motifs are physiologically significant for posttranslational modifications. Davis and Engebrecht (1998) reported that the Pelota ortholog Dom34 of S.cerevisiae contains three regions that display similarity to conserved motifs (Fig 1.1): (1) A putative nuclear localization signal (NLS) is located at residues 173-177 of the yeast protein. This sequence PKKKR is similar to PKKKRK of simian virus 40 (SV40) large T antigen. (2) Pelo protein contains three eEF1 $\alpha$-like domains. The eEF1 $\alpha$-like domain is present in several proteins such as the translation elongation factor eEF1 $\alpha$ and the translation release factors eRF1 and eRF3 (Frolova et al., 1994). (3) A putative leucine zipper motif is located at the C-terminus of S.cerevisiae protein. Leucine zippers have been suggested to mediate protein-protein interactions in a diverse set of functionally unrelated proteins (Busch and Sassone-Corsi, 1990). Alignment of the Pelo protein from 
twelve species revealed that all Pelo proteins share the NLS, eRF1 and leucine zipper motifs.

A phylogenetic analysis of Pelo primary amino acid sequences from different species using the TreeFam database is shown in Figure 1.2. The degree of sequence similarity is entirely congruent with the evolutionary relationship of the respective organisms. This is in support of the idea that the Pelo genes are all derived from the same ancestral gene.

\begin{tabular}{|c|c|c|c|c|c|c|c|}
\hline \multirow[t]{2}{*}{ Symbol } & \multirow[t]{2}{*}{ Species } & \multirow[t]{2}{*}{ Gene ID } & \multirow[t]{2}{*}{$\begin{array}{c}\text { Chromosomal } \\
\text { location }\end{array}$} & \multirow[t]{2}{*}{$\begin{array}{c}\text { mRNA } \\
\text { (bp) }\end{array}$} & \multirow[t]{2}{*}{$\begin{array}{c}\text { Protein } \\
\text { (aa) }\end{array}$} & \multicolumn{2}{|c|}{$\begin{array}{c}\text { Mouse similarity } \\
(\%)\end{array}$} \\
\hline & & & & & & DNA & protein \\
\hline Pelo & M.musculus & 105083 & $13 \mathrm{D} 2.2$ & 1624 & 385 & - & - \\
\hline PELO & H.sapiens & 53918 & $5 q 11.2$ & 1567 & 385 & 90.3 & 96.4 \\
\hline LOC479338 & C.familiaris & 479338 & 4 & 1445 & 432 & 89.1 & 96.3 \\
\hline Pelo & R.norvegicus & 294754 & $2 q 14$ & 1550 & 385 & 95.0 & 98.7 \\
\hline RCJMB04_14b4 & G.gallus & 430689 & un & 1724 & 385 & 80.1 & 92.3 \\
\hline Pelo & D.melanogaster & 34286 & $2 \mathrm{~L} 30 \mathrm{C} 5$ & 2102 & 395 & 64.1 & 66.3 \\
\hline ENSANGG0000 & A.gambiae & 1277715 & $3 R$ & 1384 & 384 & 64.6 & 66.7 \\
\hline 0005096 & & & & & & & \\
\hline R74.6 & C.elegans & 187888 & III & 1446 & 381 & 56.0 & 59.1 \\
\hline SPCC18B5.06 & S.pombe & 2539371 & III & 1173 & 390 & 51.7 & 48.3 \\
\hline PEL1 & A.thaliana & 828876 & 4 & 1168 & 378 & 53.8 & 51.5 \\
\hline $\begin{array}{l}\text { OSJNBa0011F2 } \\
3.23\end{array}$ & O.sativa & 3066857 & un & 1137 & 378 & 54.9 & 53.1 \\
\hline DOM34 & S.cerevisiae & 855731 & XIV & 2479 & 386 & 36.0 & 55.0 \\
\hline
\end{tabular}

Table 1.1: Identity (\%) of the alignment of nucleotide and amino acid sequences for Pelo gene between mouse and other species, gene ID and their chromosomal localisation (NCBI). 


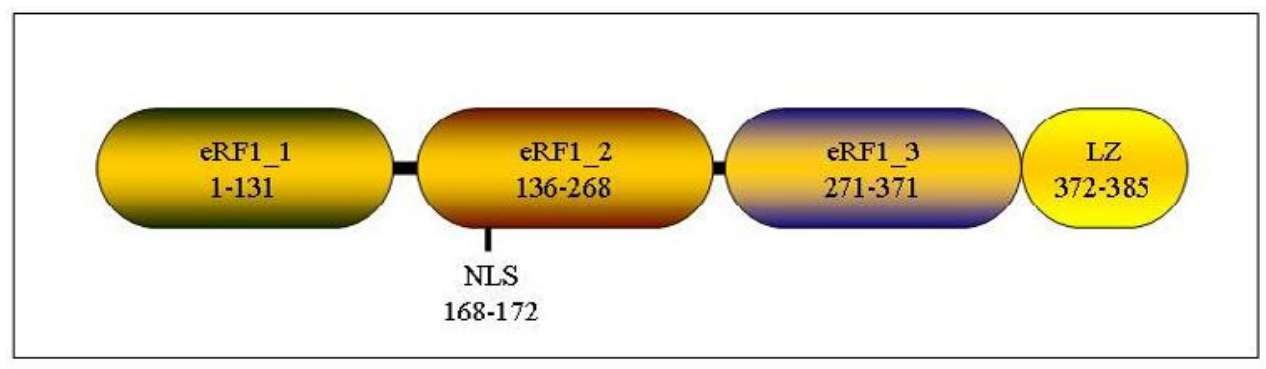

Figure 1.1: Schematic representation of Pelo protein structure

The Pelo protein contains three regions that display similarity to conserved motifs: (1) Residues 1-131, 136-268 and 271-371 are highly similar to a portion of eukaryotic peptide chain release factor subunit 1 (eRF1). The eRF1 family of proteins is involved in the termination step of protein synthesis. (2) A putative nuclear localization signal (NLS) is located at residues 168-172. This sequence is similar to that of simian virus 40 (SV40) large T antigen NLS (Dom34p, PKKKR; SV40, PKKKRKV). (3) A putative leucine zipper motif is located at the $\mathrm{C}$-terminus. Leucine zippers have been suggested to mediate proteinprotein interactions in a diverse set of functionally unrelated proteins.

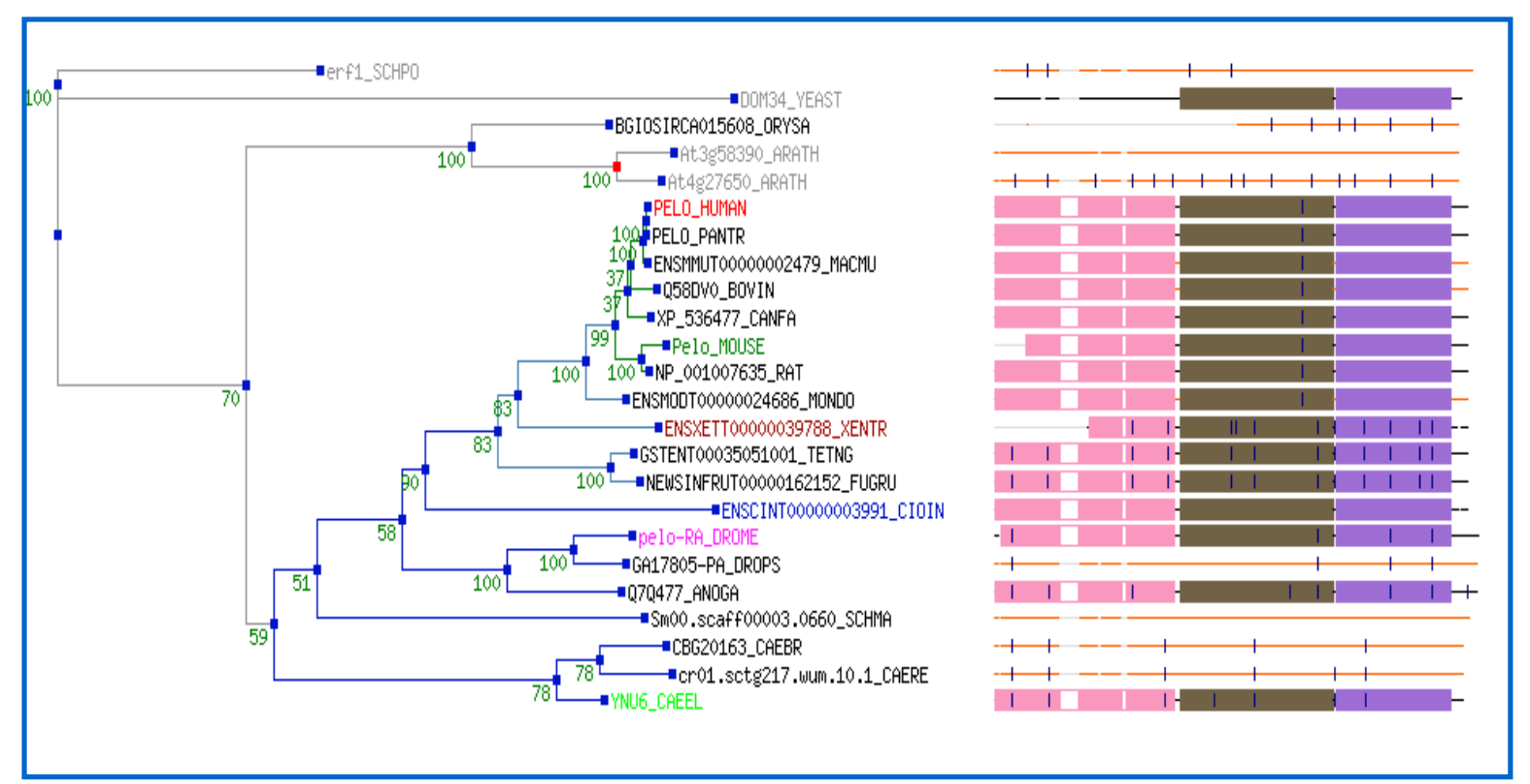

Figure 1.2: A phylogenetic tree of the Pelota gene

Alignment of the amino acid sequences of Pelota from different species using the TreeFam (Tree families) database. It was built by merging several trees together, including Phyml WAG tree, Phyml $\mathrm{HKY}, \mathrm{NJ} \mathrm{dS}$ and NJ dN tree. Branch lengths were estimated from HKY model. The red nodes stand for 
duplications and blue for speciations or undefined nodes. The green numbers denote the bootstrap values. The colored boxes correspond to Pfam domains (eRF1_1; eRF1_2 and eRF1_3, respectively), while lines to non-domain regions. Dark lines or boxes show matched parts, while light ones gaps.

Abbreviations for species: erf1_SCHPO, Schizosaccharomyces pombe; DOM34_YEAST, Saccharomyces cerevisiae; BGIOSIRCA015608_ORYSA, Oryza sativa; At3g58390_ARATH, Arabidopsis thaliana; At4g27650_ARATH, Arabidopsis thaliana; PELO_HUMAN, Homo Sapiens; PELO_PANTR, Pan troglodyte; ENSMMUT00000002479_MACMU, Macaca mulatta; Q58DV0_BOVIN, Bos taurus; XP_536477_CANFA, Canis familiaris; Pelo_MOUSE, Mus musculus; NP_001007635_RAT, Rattus norvegicus; ENSMODT00000024686_MONDO, Monodelphis domestica; ENSXETT00000039788_XENTR, Xenopus tropicalis; GSTENT00035051001_TETNG, Tetraodon nigroviridis; NEWSINFRUT00000162152_FUGRU, Takifugu rubripes; ENSCINT00000003991_CIOIN, Ciona intestinalis; pelo-RA_DROME, Drosophila melanogaster; GA17805-PA_DROPS, Drosophila pseudoobscura; Q7Q477_ANOGA, Anopheles gambiae; Sm00.scaff00003.0660_SCHMA, Schistosoma mansoni; CBG20163_CAEBR, Caenorhabditis briggsae; cr01.sctg217.wum.10.1_CAERE, Caenorhabditis remanei; YNU6_CAEEL, Caenorhabditis elegans.

\subsection{Expression and function of Pelota gene}

The expression and function of Pelo has been studied in Drosophila, yeast and mouse. Expression analysis of Pelo in Drosophila, mouse and human revealed that the gene is widely expressed in all adult tissues as well as during embryonic development (Eberhart and Wasserman, 1995; Shamsadin et al., 2000 and 2002).

The function of Pelo gene was first studied in Drosophila. Male mutants were found to be infertile (Eberhart and Wasserman, 1995). Spermatogenesis in Pelo mutants progresses normally during the four mitotic divisions. The 16 spermatocytes undergo a premeiotic S-phase and duplicate their DNA content. However, spermatocytes in the mutant arrested prior to full chromosome condensation, spindle pole organization, and nuclear breakdown. Metaphase and anaphase figures of the meiotic divisions, which are clearly recognised in squashed preparations of wildtype testis, were not observed in testis of the Pelo mutant. Although meiotic division arrests in Pelota deficient spermatocytes, germ cell differentiation continues, resulting in $4 N$ spermatids with head and tail structures. These results indicate that the Pelo is required for the meiotic division during the $\mathrm{G}_{2} / \mathrm{M}$ transition (Eberhart and Wasserman, 1995). The ovaries of 
Pelota homozygous flies are very small. The mitotic zone of ovaries appears disorganised and often contains degenerating cells. Later stages of oogenesis are also affected. The female mutants produce less than 50\% eggs. The results suggest that Pelo gene is also required for mitotic division in the ovary. Beside the effect of the mutation on spermatogenesis and oogenesis, the eyes of the Pelo homozygotes are up to $30 \%$ smaller than those of wildtype siblings. These results indicate that Pelota is required for Drosophila eye development.

Analysis of mitotic and meiotic division in the dom34 mutant of Saccharomyces cerevisiae, which has a mutation in the Pelota orthologous gene, reveals that the dom 34 mutant exhibits a G1 delay, while the meiotic division occurs too rapid and fewer spores are produced as compared to wildtype. The yeast mutant also fails to segregate chromosomes properly (Davis and Engebrecht, 1998). Introduction of the Drosophila wildtype pelota transgene into a dom 34 mutant was found to result in substantial rescue of the dom34 growth and sporulation defects (Eberhart and Wasserman, 1995).

To analyse the function of Pelo in mammalian species, Pelo gene was disrupted by homologous recombination in the mouse (Adham et al., 2003). Heterozygous Pelo ${ }^{+/-}$ male and female mice show no apparent abnormalities in development or fertility, indicating that one functional copy of the gene is sufficient for normal development. Genotyping of the progeny of heterozygous intercrosses indicated the absence of Pelo ${ }^{-/-}$ pups and suggests an embryo-lethal phenotype. To assess the consequences of the Pelo mutation for embryonic development, embryos were collected from heterozygous intercrosses at different days of gestation and genotyped. The results revealed that $\mathrm{Pelo}^{-/-}$ embryos die between E3.5 and E8.5.

To determine the causes and time of embryonic lethality, deciduae at E6.5, E7.5, and E8.5 were dissected and histologically analysed. Mutant embryos at E7.5 and E8.5 were found to be smaller and developmentally retarded as compared to their normal littermates. However, the embryonic germ layers (ectoderm, mesoderm and endoderm) are developed. These results indicate that $\mathrm{Pelo}^{-/-}$embryos have the capacity to generate some of the features of a gastrulated embryos despite impaired growth, and manifest their phenotype between days 6.5 and 7.5 of embryonic development.

In vitro culture of blastocysts revealed the impaired growth and the death of mitotic active inner cell mass (ICM) of Pelo-/- blastocysts, and the survival of mitotic inactive 
trophoblast cells of $\mathrm{Pelo}^{-/-}$blastocysts. These results demonstrate that Pelo is essential for the normal mitotic division and for early embryonic development in the mouse. Analysis of the cellular DNA content revealed the significant increase of aneuploid cells in Pelo $^{-/-}$embryos at E7.5. Therefore, the percentage of aneuploid cells at E7.5 may be directly responsible for the arrested development and suggests that Pelo is required for maintenance of genomic stability.

Early developmental arrest of the Pelo deficient embryos and subsequently the failure to establish a $\mathrm{Pelo}^{-/-}$cell line prevented us to define the cause of aneuploidy observed in cells of the mutant embryos. Even though Pelo is required for regulating cell cycle progression from yeast to mammals, it remains unclear how Pelo accomplish this function. Therefore, we have aimed the following objectives to study the distinct function of murine Pelo gene.

\subsection{Objectives of this study}

The first aim of this work was the generation of a polyclonal antibody against Pelo protein. This antibody should be used for the subcellular localisation of Pelo and for analysis of the expression pattern at protein level.

The second goal was to determine the consequence of Pelo knockdown on cell proliferation using Tet inducible siRNAs system.

The third purpose was the generation of a Pelo conditional knockout mouse utilising the inducible $C r e / l o x P$ recombination system to circumvent early embryonic lethality and to establish a Pelo $^{-/-}$cell line.

The fourth aim was to generate transgenic Pelo mice to study the effect of overexpression of the gene. 


\section{MATERIALS AND METHODS}

\subsection{Materials}

\subsubsection{Chemicals}

1 kb DNA Ladder

Acetic acid

Acrylamide

Agar

Agarose

Ammonium acetate

Ammonium persulfate

Ampicillin

Ampuwa

Aprotinin

Aqua Poly/Mount

Bacto-tryptone

Bacto-Yeast-Extract

BCIP

Bisacrylamide

Blasticidin

Blocking powder

BSA

Cell culture media

Chemiluminescent Substrate

Chloroform

Colcemid

Coomassie Blue G-250

Dextran sulfate

Diethyl pyrocarbonate (DEPC)

Dimethyl sulfoxid (DMSO)
Invitrogen, Karlsruhe

Merck, Darmstadt

Serva, Heidelberg

Difco, Detroit, USA

Invitrogen, Karlsruhe

Fluka, Neu Ulm

Sigma, Deisenhofen

Sigma, Deisenhofen

Fresenius, Bad Homburg

Sigma, Deisenhofen

Polysciences, Inc, USA

Difco, Detroit, USA

Difco, Detroit, USA

Boehringer, Mannheim

Serva, Heidelberg

Sigma, Deisenhofen

Boehringer, Mannheim

Biomol, Hamburg

PAN-Systems, Nürnberg

Pierce, Rockford, IL

Baker, Deventer, NL

Sigma, Deisenhofen

Sigma, Deisenhofen

Amersham Pharmalia, Freiburg

Sigma, Deisenhofen

Merck, Darmstadt 
Dithiothreitol

dNTPs

Doxycycline

Dye Terminator Mix

EDTA

EGTA

Ethanol

Ethidium bromide

Eukitt-quick hardening mounting medium

FBS

Ficoll 400

Formaldehyde

Formamide

Freund's adjuvant

Glutaraldehyde

Glycerol

Glycine

Goat serum

$\mathrm{HCl}$

$\mathrm{H}_{2} \mathrm{O}_{2}$

HEPES

4-Hydroxytamoxifen

Horse serum

IPTG

Isopropanol

$\mathrm{KCl}$

$\mathrm{KH}_{2} \mathrm{PO}_{4}$

Lambda DNA

Leupeptin

Lipofectamine $2000 \mathrm{TM}$

Methanol

2-Mercaptoethanol

Methyl benzoat

$\mathrm{MgCl}_{2}$
Sigma, Deisenhofen

Invitrogen, Karlsruhe

Sigma, Deisenhofen

Applied Biosystems,

ICN Biomedicals, Eschwege

Applichem, Darmstadt

Baker, Deventer, NL

Sigma, Deisenhofen

Fluka, Neu Ulm

Invitrogen, Karlsruhe

Amersham Pharmalia, Freiburg

Invitrogen, Karlsruhe

Fluka, Neu Ulm

Sigma, Deisenhofen

Sigma, Deisenhofen

Invitrogen, Karlsruhe

Biomol, Hamburg

PAN-Systems, Nürnberg

Merck, Darmstadt

Merck, Darmstadt

Merck, Darmstadt

Sigma, Deisenhofen

PAN-Systems, Nürnberg

Biomol, Hamburg

Merck, Darmstadt

Merck, Darmstadt

Merck, Darmstadt

Roche, Penzberg

Sigma, Deisenhofen

Invitrogen, Karlsruhe

Merck, Darmstadt

Serva, Heidelberg

Fluka, Neu Ulm

Merck, Darmstadt 
Milk powder

Mineral oil

MOPS

$\mathrm{NaCl}$

$\mathrm{Na}_{2} \mathrm{HPO}_{4}$

$\mathrm{NaH}_{2} \mathrm{PO}_{4}$

$\mathrm{NaHCO}_{3}$

$\mathrm{NaN}_{3}$

$\mathrm{NaOH}$

NBT

Nonidet P40

Nocodazol

NuPAGE Novex Bis-Tris 4-12\% Gel

NuPAGE MOPS SDS running buffer

NuPAGE SDS sample buffer

Orange $\mathrm{G}$

OptiMEM I

Paraformaldehyde

PBS

Penicillin/Streptomycin

Peptone

Phalloidin

Phenol

Phosphoric acid

Picric acid

Protein A/G PLUS Agarose

Proteinase K

Protein marker

$\left[\alpha^{32} \mathrm{P}\right]-\mathrm{dCTP}$

Rediprime $^{\mathrm{TM}} \mathrm{II}$

RNase A

RNase away

RNase Inhibitor

RNA length standard
Roth, Karlsruhe

Sigma, Deisenhofen

Merck, Darmstadt

Merck, Darmstadt

Merck, Darmstadt

Merck, Darmstadt

Merck, Darmstadt

Merck, Darmstadt

Merck, Darmstadt

Roche, Penzberg

Fluka, Neu Ulm

Sigma, Deisenhofen

Invitrogen, Karlsruhe

Invitrogen, Karlsruhe

Invitrogen, Karlsruhe

Sigma, Deisenhofen

Invitrogen, Karlsruhe

Merck, Darmstadt

PAN-Systems, Nürnberg

PAN-Systems, Nürnberg

Roth, Karlsruhe

Sigma, Deisenhofen

Biomol, Hamburg

Merck, Darmstadt

Fulka, Neu Ulm

Santa Cruz Biotechnology

Roche, Penzberg

Biorad, Sigma

Amersham Pharmalia, Braunschweig

Amersham Pharmacia, Freiburg

Qiagen, Hilden

Biomol, Hamburg

Roche, Penzberg

Invitrogen, Karlsruhe 
Salmon sperm DNA

SDS

SeeBlue Plus2 Pre-Stained Standart

Select Peptone

S.O.C Medium

Sodium acetate

Sodium citrate

Sun flower oil

SuperScript II

T4 DNA ligase

Tamoxifen

TEMED

TRI reagent

Tris base

Triton X-100

Trypsin

Tween-20

Vectashield (DAPI)

X-Gal

Xylene

Xylencyanol

Yeast extract

Zeocin
Sigma, Deisenhofen

Serva, Heidelberg

Invitrogen, Karlsruhe

Gibco/BRL, Eggenstein

Invitrogen, Karlsruhe

Merck, Darmstadt

Merck, Darmstadt

Sigma, Deisenhofen

Invitrogen, Karlsruhe

Promega, Mannheim

Sigma, Deisenhofen

Serva, Heidelberg

Sigma, Deisenhofen

Sigma, Deisenhofen

Serva, Heidelberg

PAN-Systems, Nürnberg

Sigma, Deisenhofen

Vector, Burlingame

Biomol, Hamburg

Merck, Darmstadt

Bio-Rad, München

Roth, Karlsruhe

Sigma, Deisenhofen

All those chemicals which are not mentioned above were bought from Merck, Darmstadt, or Roth, Karlsruhe. 


\subsubsection{Solutions, buffers and media}

\subsubsection{Agarose gel electrophoresis}

All standard buffers and solutions were prepared according to Sambrook et al. (1989).

$5 \times$ TBE buffer

Glycerol loading buffer -I

Glycerol loading buffer-II

\subsubsection{SDS-PAGE}

40\% Acrylamide stock solution

Sample buffer $(2 \mathrm{x})$
$450 \mathrm{mM}$ Tris base

$450 \mathrm{mM}$ Boric acid

20 mM EDTA (pH 8)

$10 \mathrm{mM}$ Tris/ $\mathrm{HCl}(\mathrm{pH} 7.5)$

10 mM EDTA (pH 8)

0.025\% Bromophenol blue

$0.025 \%$ Xylenecyanol

$30 \%$ Glycerol

$10 \mathrm{mM}$ Tris/ $\mathrm{HCl}(\mathrm{pH} 7.5)$

10 mM EDTA (pH 8)

$0.025 \%$ Orange G

$30 \%$ Glycerol

Acrylamide $29.2 \%(\mathrm{w} / \mathrm{w})$

Bis-acrylamide $0.8 \%(\mathrm{w} / \mathrm{w})$

10\% Ammonium persulfate

solution in $\mathrm{H}_{2} \mathrm{O}$

$0.5 \mathrm{M}$ Tris $/ \mathrm{HCl}(\mathrm{pH} 6.8)$

$20 \%$ Glycerol

$4 \%$ SDS

$10 \% \beta$-Mercaptoethanol 
Running buffer (5x)

$25 \mathrm{mM}$ Tris/ $\mathrm{HCl}(\mathrm{pH} 8.3)$

$192 \mathrm{mM}$ Glycine

$0.1 \%$ SDS

Stacking gel buffer (4x)

$0.5 \mathrm{M}$ Tris/ $\mathrm{HCl}(\mathrm{pH} 6.8)$

$0.4 \%$ SDS

Separating gel buffer $(4 \mathrm{x})$

1.5 M Tris/HCl (pH 8.3)

$0.4 \%$ SDS

\subsubsection{Frequently used buffers and solutions}

Denaturation solution

$1.5 \mathrm{M} \mathrm{NaCl}$

$0.5 \mathrm{M} \mathrm{NaOH}$

Denhardt's solution $(50 \mathrm{x})$

$1 \% \mathrm{BSA}$

$1 \%$ Polyvinylpyrrolidon

1\% Ficoll 400

Depurination solution

$250 \mathrm{mM} \mathrm{HCl}$

E-buffer (10x)

$300 \mathrm{mM} \mathrm{NaH}_{2} \mathrm{PO}_{4}$

$50 \mathrm{mM}$ EDTA

Elution buffer

$1.5 \mathrm{M} \mathrm{NaCl}$

$20 \mathrm{mM}$ Tris/ $\mathrm{HCl}(\mathrm{pH} 7.5)$

1 mM EDTA

Bouin's solution

15 volume of Picric acid (in $\mathrm{H}_{2} \mathrm{O}$ )

5 volumes Formaldehyde

1 volume Acetic acid 
Hybridisation solution I

Hybridisation solution II

Ligation buffer (10x)

Lysis buffer I

Lysis buffer II

Lysis buffer III (embryo)

Lysis buffer IV
$5 \times$ SSPE solution

$5 \mathrm{x}$ Denhardt's solution

$0.1 \%$ SDS

$5 \times \mathrm{SSC}$

$5 \mathrm{x}$ Denhardt's solution

10\% Dextran sulfate

$0.1 \%$ SDS

600 mM Tris/HCl (pH 7.5)

$80 \mathrm{mM} \mathrm{MgCl}_{2}$

100 mM DTT

$100 \mathrm{mM}$ Tris/HCl (pH 8.0)

$100 \mathrm{mM} \mathrm{NaCl}$

$100 \mathrm{mM}$ EDTA

$0.5 \%$ SDS

$100 \mathrm{mM}$ Tris/HCl (pH 8.0)

5 mM EDTA

$200 \mathrm{mM} \mathrm{NaCl}$

$0.2 \%$ SDS

$100 \mu \mathrm{g} / \mathrm{ml}$ Proteinase K

50 mM Tris/ $\mathrm{HCl}(\mathrm{pH} 8.0)$

0.5 mM EDTA (pH 8.0)

$0.5 \%$ Tween 20

$0.2 \mathrm{mg} / \mathrm{ml}$ Proteinase K

$1 \%$ Tween 20

$1 \%$ Triton X-100

5 mM EDTA

$10 \mathrm{mM}$ Tris $\mathrm{pH} 7.5$

2 mM DTT 
$20 \mu \mathrm{l} / \mathrm{ml}$ Proteinase K

Lysis buffer A

$10 \mathrm{mM}$ Tris $/ \mathrm{HCl} \mathrm{pH} 8.0$

1 mM EDTA

$2.5 \%$ SDS

$1 \mathrm{mM}$ PMFS

Lysis buffer B

$50 \mathrm{mM}$ Tris/HCl, $\mathrm{pH} 7.5$

$150 \mathrm{mM} \mathrm{NaCl}$

$1 \%$ Nonidet P40

$0.5 \%$ Sodium deoxycholate

1 Protease inhibitor cocktail tablet

10 X MOPS Buffer

$41.8 \mathrm{~g}$ MOPS

$16.6 \mathrm{ml} 3 \mathrm{M}$ Sodium acetate

$20 \mathrm{ml} \mathrm{0.5} \mathrm{M} \mathrm{EDTA}$

in 1 liter of DEPC water

adjust $\mathrm{pH}$ to 6.75

Neutralisation solution

$1.5 \mathrm{M} \mathrm{NaCl}$

$1 \mathrm{M}$ Tris/ $\mathrm{HCl}$ (pH 7.0)

PBS buffer

$130 \mathrm{mM} \mathrm{NaCl}$

$7 \mathrm{mM} \mathrm{Na}_{2} \mathrm{HPO}_{4}$

$4 \mathrm{mM} \mathrm{NaH}_{2} \mathrm{HPO}_{4}$

PBT buffer

$0.1 \%$ Tween-20 in PBS (1x)

$\operatorname{SSC}(20 x)$

$3 \mathrm{M} \mathrm{NaCl}$

$0.3 \mathrm{M} \mathrm{Na}_{3}$ citrate ( $\mathrm{pH}$ 7.0)

SSPE (20x)

0.02 M EDTA

$0.2 \mathrm{M} \mathrm{NaH}_{2} \mathrm{PO}_{4}$

3.6 M NaCl (pH 7.0) 
Stop-Mix I

Stop-Mix II

TE buffer

Washing solution I

Washing solution II
95\% Formamide

$20 \mathrm{mM}$ EDTA

0.05\% Bromphenol blue

$0.05 \%$ Xylene cyanol

$15 \%$ Ficoll 400

200 mM EDTA

$0.1 \%$ Orange G

$10 \mathrm{mM}$ Tris/ $\mathrm{HCl}(\mathrm{pH} 8.0)$

$1 \mathrm{mM}$ EDTA

$2 \times \mathrm{SSC}$

$0.1 \%$ SDS

$0.2 \times \mathrm{SSC}$

$0.1 \%$ SDS 


\subsubsection{Laboratory materials}

The laboratory materials, which are not listed here, were bought from Schütt and Krannich (Göttingen).

Cell culture flask

Greiner, Nürtingen

Culture slides

BD Falcon, Heidelberg

Disposable filter Minisart NMI

Sartorius, Göttingen

Filter paper 0858

Schleicher and Schüll, Dassel

Hybond C

Amersham, Braunschweig

Hybond N

Amersham, Braunschweig

HPTLC Aluminum folio

Merck, Darmstadt

Microcentrifuge tubes

Eppendorf, Hamburg

Petri dishes

Greiner, Nürtingen

Pipette tips

Eppendorf, Hamburg

RotiPlast paraffin

Roth, Karlsruhe

Transfection flasks

Lab-Tek/Nalge, Nunc, IL, USA

Superfrost slides

Menzel, Gläser

Whatman blotting paper

Schleicher and Schüll, Dassel

(GB 002, GB 003 and GB 004)

X-ray films

Amersham, Braunschweig 


\subsubsection{Sterilisation of solutions and equipments}

All solutions that are not heat sensitive were sterilised at $121^{\circ} \mathrm{C}, 10^{5} \mathrm{~Pa}$ for $60 \mathrm{~min}$ in an autoclave (Webeco, Bad Schwartau). Heat sensitive solutions were filtered through a disposable sterile filter ( 0.2 to $0.45 \mu \mathrm{m}$ pore size). Plastic wares were autoclaved as above. Glasswares were sterilised overnight in an oven at $220^{\circ} \mathrm{C}$.

\subsubsection{Media, antibiotics and agar-plates}

\subsubsection{Media for bacteria}

LB Medium ( $\mathrm{pH} 7.5)$

$$
\begin{aligned}
& 1 \% \text { Bacto-trypton } \\
& 0.5 \% \text { Yeast extracts } \\
& 1 \% \mathrm{NaCl}
\end{aligned}
$$

LB-Agar

$$
\begin{aligned}
& 1 \% \text { Bacto-trypton } \\
& 0.5 \% \text { Yeast extracts } \\
& 1 \% \mathrm{NaCl} \\
& 1.5 \% \text { Agar }
\end{aligned}
$$

The LB medium was prepared with distilled water, autoclaved and stored at $4{ }^{\circ} \mathrm{C}$. 


\subsubsection{Media for cell and embryo culture}

M2 and M16 media were purchased from Sigma (Deisenhofen) and were used for washing and cultivation of mouse preimplantation embryos.

Embryonic stem (ES) cell medium:

DULBECCO's Modified Eagles Media (DMEM)

$1 \mathrm{mM}$ Non essential amino acids

$1 \mathrm{mM}$ Sodium pyruvate

$10 \mu \mathrm{M}$ B-Mercaptoethanol

2 mM L-Glutamine

$20 \%$ FCS

$1000 \mathrm{U} / \mathrm{ml}$ Recombinant leukaemia inhibitory factor (LIF)

Fibroblast cell medium (MEFs):

DULBECCO's Modified Eagles Media (DMEM)

2 mM L-Glutamine

$10 \%$ FCS

$1 \%$ penicillin/streptomycin

For long time storage of the cells in liquid nitrogen, the following freezing medium was used:

$$
\begin{array}{lll}
\text { Freezing medium: } & 20 \% & \text { FCS } \\
& 10 \% & \text { DMSO in DMEM }
\end{array}
$$




\subsubsection{Antibiotics}

Stock solutions were prepared for the antibiotics. The stock solutions were then filtered through sterile disposable filters and stored at $-20^{\circ} \mathrm{C}$. When antibiotics were needed, in each case, it was added after the autoclaved medium has cooled down to a temperature lower than $55^{\circ} \mathrm{C}$.

$\begin{array}{lll}\text { Antibiotics } & \text { Stock solution } & \text { Working solution } \\ \text { Ampicillin } & 50 \mathrm{mg} / \mathrm{ml} & 50 \mu \mathrm{g} / \mathrm{ml} \\ \text { Kanamycin } & 25 \mathrm{mg} / \mathrm{ml} & 50 \mu \mathrm{g} / \mathrm{ml}\end{array}$

\subsubsection{IPTG/X-Gal plate}

LB-agar with $50 \mu \mathrm{g} / \mathrm{ml}$ ampicillin, $100 \mu \mathrm{M}$ IPTG and $0.4 \%$ X-Gal was poured into Petri dishes. The dishes were stored at $4{ }^{\circ} \mathrm{C}$.

\subsubsection{Bacterial strains}

E. coli DH5 $\alpha$

K-12 strain,F- $\Phi 80 d$ lacZ $\Delta \mathrm{M} 15$ endA1

recA1 hsdR17 (rk-, mk+) sup E44 thi-1

d- $g y r$ A96 $\Delta$ (lacZYA-arg)

(Invitrogen, Karlsruhe)

E. coli BL21 (DE3)

B strain, F- omp T hsdSв(rв- mв-) gal, Dcm

(Novagen, Darmstadt)

\subsubsection{Eukaryotic strains}

NIH 3 T3

HeLa

$\mathrm{LNCaP}$

PC-3
Mouse embryonic fibroblast cell line, ATCC, Rockville, USA Human cervical adenocarcinoma cell line, ATCC, Rockville, USA Human prostate carcinoma cell line, ATCC, Rockville, USA Human prostate carcinoma cell line, ATCC, Rockville, USA 


\subsubsection{Plasmids}

$\begin{array}{ll}\text { pBluesript SK }(+/-) & \text { (Stratagene, La Jolla, USA) } \\ \text { pcDNA6/TR } & \text { (Invitrogen BV, Groningen, The Netherlands) } \\ \text { pGEMTeasy } & \text { (Promega, Wisconsin, USA) } \\ \text { pEF-BOS } & \left(\text { BCCM }^{\mathrm{TM}} / \text { LMBP Plasmid collection, Belgium) }\right. \\ \text { pET } 41 \text { (a-b) }_{\text {pTER }^{+}} & \text {(Novagen, Darmstadt, Germany) } \\ \text { pUB } / \text { V5-His A }^{-} & \text {(Invitrogen, Darmstadt, Germany) } \\ & \text { (Invitrogen, Darmstadt, Germany) }\end{array}$

\subsubsection{Synthetic oligonucleotides}

The synthetic oligonucleotide primers used in this study were obtained from OPERON and dissolved in $\mathrm{dH}_{2} \mathrm{O}$ (Ampuwa) to a final concentration of $100 \mathrm{pmol} / \mu 1$. 


\begin{tabular}{|c|c|}
\hline Name & Sequence \\
\hline PelocKO-F & 5' CTTCCCAGTGCCAGAACTTT 3' \\
\hline PelocKO-R & 5' AATTCGGAAACACCAAGTCG 3' \\
\hline PGK-1 & 5' TCTGAGCCCAGAAAGCGAAGG 3' \\
\hline Pelo-F11 & 5' TGAGCCCAGACTGTACGTGAC 3' \\
\hline Pelo-R13 & 5' TTCCCGGAACATCCCTGTGTG 3' \\
\hline PGK3_B & 5' GGATGTGGAATGTGTGCGAGG 3' \\
\hline Pelo 5’-F1 & 5' GCATGTAACAGGAGTTATGATGGA 3' \\
\hline Pelo 5'-R1 & 5' TACTACATTATTTGCCCTTCTGTG 3' \\
\hline Pelo 5'-F2 & 5' AGACTGCAGCTGAGTCAGTACTGA 3' \\
\hline Pelo 5'-R2 & 5' GTTCACTTTGTATAGGAGAGAGAT 3' \\
\hline Pelo-3'-F1 & 5' GCAAGATTTTGACTACATTCAC 3' \\
\hline Pelo-3'-R1 & 5' CATGTGCTACACTGAGGCTTGT 3' \\
\hline mPelotaF1Wlof & 5' TGAAGGGGACCAATATCCAA 3' \\
\hline mPelotaR1Wlof & 5’'AAGGAATTTGGAGCGGTTTT 3' \\
\hline Pelo-GFPR1 & 5' CCCTCTAGAACTAGAGAATATCCTAACGGTGC 3' \\
\hline Pelo-GFPR2 & 5' CCCTCTAGATTTAGTGTCTGAAAGGCGGCTAG 3' \\
\hline Pelo:3-F1 & 5' GCAAGATTTTGACTACATTCAC 3' \\
\hline Pelo:3-R1 & 5' CATGTGCTACACTGAGGCTTGT 3' \\
\hline Pelo-Lox.F1 & 5' CACGCTAAGGTGCAGAATGAT 3' \\
\hline Pelo-Lox.R1 & 5' CGGTCAGCGCTCTGAAAA 3' \\
\hline Neo-F1 & 5' GCCTTCTATCGCCTTCTTGA 3' \\
\hline Pelo-Lox.R4 & 5' GAGGAAAACCAAGAAAAGTTGG 3' \\
\hline RosaCreER-F & 5' ACCAGCCAGCTATCAACTC 3' \\
\hline RosaCreER-R & 5'TATACGCGTGCTAGCGAAGATCTCCATCTTCCAGCAG 3' \\
\hline EIIa-CreF & 5' CCAGGCTAAGTGCCTTCTCTACA 3' \\
\hline EIIa-CreR & 5' AATGCTTCTGTCCGTTTGCCGGT 3' \\
\hline mPelo-3ext-F & 5' GTGCGAGAAGGCCAGTTCTA 3' \\
\hline mPelo-3ext-R & 5' AGGCTGACCATCTGTGGTGT 3' \\
\hline pET-1g-F & 5' GGGGAAGTCAAAGCCTTGGATG 3' \\
\hline pET-1g-R & 5' TTCGGGAACAGGGAAGCGGAGA 3' \\
\hline pET-2a-F & 5' CCCAACCGCCAGTTCACCCTGG 3' \\
\hline
\end{tabular}




\begin{tabular}{|c|c|}
\hline pET-2a-R & 5' AGTGTCTGAAAGGCGGCTAGCC 3' \\
\hline hPelo-F20 & 5' CCCTCTAGACTTCCTTGGCCATGAAGCTCG 3' \\
\hline hPelo-R20 & 5' GGGTCTAGACTTGCAGCTTTCTGTCACAAGG 3' \\
\hline mPelo.RT-PCR-F1 & 5', TCTGGGTTAACTGGATCGTG 3', \\
\hline mPelo.RT-PCR-R1 & 5' GAGGACTCGGTCTGGACCTT 3' \\
\hline mPelo.RT-PCR-F2 & 5' ATCCAGCGCCACATAAACTT 3' \\
\hline mPelo.RT-PCR-R2 & 5' CTCTCCACCTGCTTGAGTCC 3' \\
\hline mPelo.RT-PCR-F3 & 5' CTGCTTAGTCACTCCCAGCA 3' \\
\hline mPelo.RT-PCR-R3 & 5' CGGAAGAGCTCGTCACTGAT 3' \\
\hline mPelo.RT-PCR-F4 & 5' GATGTGGCAGCTGTGGTCAT 3' \\
\hline mPelo.RT-PCR-R4 & 5' CTCCTTCACACTGTCCACCA 3' \\
\hline mGAPDH-F & 5' CACCACCAACTGCTTAGCC 3' \\
\hline mGAPDH-R & 5' CGGATACATTGGGGGTAGG 3' \\
\hline PeloHA-F1 & 5' CCCGAATTCAGCTCGTGAGGAAGAACATC 3' \\
\hline PeloHA-R1 & 5' ACCCTCGAGTTAATCCTCTTCAGAACTGGAATC 3' \\
\hline GFP-Filamin-F1 & 5’ AGCCAAGCTTGCCCCTCCAAGGTGAAGATGG 3' \\
\hline GFP-Filamin-R1 & 5' GGGAGATCTCAGACTCAGGGCACCACAACG 3' \\
\hline GFP-Actinin-F1 & 5' AGCCAAGCTTGCAACCGGCCTGCCTTCATGC 3' \\
\hline GFP-Actinin-R1 & 5' GGGAGATCTGTGGATTAGAGGTCACTCTCG 3' \\
\hline hPelo-F20 & 5' CCCTCTAGACTTCCTTGGCCATGAAGCTCG 3' \\
\hline hPelo-R20 & 5' GGGTCTAGACTTGCAGCTTTCTGTCACAAGG 3' \\
\hline Trans.pEF-F & 5' CATTCTCAAGCCTCAGACAGTG 3' \\
\hline Trans.pUB-F & 5' TCAGTGTTAGACTAGTAAATTG 3' \\
\hline Trans.hPelo-R1 & 5' GAGGACTCTGTCTGTACCTTG 3' \\
\hline Trans.hPelo-R2 & 5' CAGGCTTGAGAGTCGAAGTC 3' \\
\hline GSF-F1 & 5' GAGTATCAGGTCTCCCACGTG 3' \\
\hline GSF-R1 & 5' GGAGCTTCCTTTCACACACAG 3' \\
\hline GSF-R2 & 5' AGGGGTGCAAGGACCCAGATG 3' \\
\hline GFP-Filamin-R1 & 5' GGGAGATCTCAGACTCAGGGCACCACAACG 3' \\
\hline pUB-F1 & 5' CTCCTCGGTCTCGATTCTACG 3' \\
\hline pUB-R1 & 5' AAAGGACAGTGGGAGTGGCAC 3' \\
\hline pUB-R2 & 5’ AGGGTTAGGGATAGGCTTACC 3' \\
\hline hPelo-F21 & 5' GACCGGTTTTCCAGGAGCAGT 3' \\
\hline
\end{tabular}




$\begin{array}{ll}\text { BC057160-706_S } & \text { 5' GATCCCCACCGCTCCAAATTCCTTCATTCAAGAG } \\ \text { BC057160-706_As } & \text { 5'AGCTTAAAAAACCGCTCCAAATTCCTTCATCTCTTGAATGAA } \\ \text { PeloRNAiS1 } & \text { TGAAGGAATTTGGAGCGGTGGG 3' } \\ \text { 5'GATCCCCCACAAGTACTCCCTGAAAGTTCAAGAGACTTTCAG } & \text { GGAGTACTTGTGTTTTTGGAAA 3' } \\ \text { PeloRNAiA1 } & \text { 5'AGCTTTTCCAAAAACACAAGTACTCCCTGAAAGTCTCTTGAA } \\ \text { PeloRNAiS2 } & \text { CTTTCAGGGAGTACTTGTGGGG 3' } \\ & \text { 5'GATCCCCGTTCACCCTGGCCAAGAAATTCAAGAGATTTCTTG } \\ \text { PeloRNAiA2 } & \text { GCCAGGGTGAACTTTTTGGAAA 3' } \\ & \text { 5'AGCTTTTCCAAAAAGTTCACCCTGGCCAAGAAATCTCTTGAA } \\ \text { CNXsense } & \text { TTTCTTGGCCAGGGTGAACGGG 3' } \\ \text { CNXanti } & \text { 5' (Phosp)CGATGCGGCCGCC 3' } \\ \text { Sense-CNX } & \text { 5' (Phosp)TCGAGGCGGCCGCAT 3' } \\ \text { Anti-SNX } & \text { 5' CCCCCCATCGATGCGGCCGCC 3' } \\ & \text { 5' AAAACCCTCGAGGCGGCCGCA 3' }\end{array}$

\subsubsection{Mouse strains}

Strains C57BL/6J, 129/Sv, CD-1 and NMRI were initially ordered from Charles River Laboratories, Wilmington, USA, and needed in Animal Facility of Institute of Human Genetics, Göttingen. ROSA26CreER ${ }^{\mathrm{T}}$ (Berns A, Netherlands) and EIIaCre (Lakso et al., 1996) mice were kindly provided by Prof. Dr. med. H. Hahn, Institute of Human Genetics, Göttingen.

\subsubsection{Antibodies}

Goat anti-mouse IgG alkaline phosphatase conjugate

Goat anti-rabbit IgG alkaline phosphatase conjugate

Goat anti-rabbit IgG Cy3 conjugate

Goat anti-rabbit GFP antiserum

Rabbit anti-mouse IgG Cy3 conjugate

Goat anti-rabbit IgG FITC conjugate

Rabbit anti-mouse IgG FITC conjugate

Mouse monoclonal anti $\alpha$-tubulin
Sigma, Deisenhofen Sigma, Deisenhofen Sigma, Deisenhofen Sigma, Deisenhofen Sigma, Deisenhofen Sigma, Deisenhofen Sigma, Deisenhofen Sigma, Deisenhofen 
Mouse monoclonal anti actin

Mouse monoclonal anti $\alpha$-actinin

Goat anti-rabbit IgG horse radish preoxidase conjugate

Rabbit anti-mouse IgG horse radish preoxidase conjugate

Rabbit anti Pelota polyclonal antibody

Rabbit anti SX polyclonal antibody
Sigma, Deisenhofen

Sigma, Deisenhofen

Sigma, Deisenhofen

Sigma, Deisenhofen

Institute of Human Genetics

Institute of Human Genetics

Polyclonal anti-Pelota and -SX antibodies were generated in the Institute of Human Genetics by immunisation of rabbits with GST-Pelota and GST-SX fusion proteins.

\subsubsection{Enzymes}

Collagenase (Type II)

(Sigma, Deisenhofen)

Immolase DNA Polymerase

(Bioline, Luckenwalde)

Klenow Fragment

(Invitrogen, Karlsruhe)

PfuI DNA polymerase

(Promega, Mannheim)

Proteinase K

(Sigma, Deisenhofen)

Platinum Taq polymerase

(Invitrogen, Karlsruhe)

Restriction enzymes (with supplied buffers)

(Invitrogen, Karlsruhe)

RNase A

(Qiagen, Hilden)

RNase H

(Invitrogen, Karlsruhe)

RNase inhibitor

(Invitrogen, Karlsruhe)

Superscript-II

(Invitrogen, Karlsruhe)

Taq polymerase

(Invitrogen, Karlsruhe)

T4 DNA ligase

(Promega, Mannheim)

Trypsin

(Invitrogen, Karlsruhe) 


\subsubsection{Radioactive substances}

$\alpha-{ }^{32} \mathrm{P}-\mathrm{dCTP}$

(Amersham, Braunschweig)

\subsubsection{Kits}

BigDye Terminator Cycle

(Applied Biosystems)

Endo Free Plasmid Maxi Kit

(Qiagen, Hilden)

GST-Bind kit

HiTrap NHS-activated

(Novagen, Darmstadt)

Megaprime DNA Labeling Kit

(Amersham Biosciences, Sweden)

Maxi Plasmid Kit

(Amersham Pharmacia, Freiburg)

Mega Plasmid Kit

(Qiagen, Hilden)

Midi Plasmid Kit

(Qiagen, Hilden)

Mini Plasmid Kit

(Invitrogen, Karlsruhe)

(Qiagen, Hilden)

PCR Purification Kit

(Qiagen, Hilden)

Protein Refolding Kit

QIAquick Gel Extraction Kit

(Novagen, Darmstadt)

RNAeasy Kit

(Qiagen, Hilden)

Rediprime $^{\mathrm{TM}}$ II Random Prime

(Qiagen, Hilden)

Labelling System

(Amersham Pharmacia, Freiburg)

One step RT-PCR kit

(Qiagen, Hilden)

(Qiagen, Hilden) 


\subsubsection{Equipment}

Autoclave

(Webeco, Bad Schwartau)

Centrifuge 5415D

(Eppendorf, Hamburg)

Centrifuge 5417R

(Eppendorf, Hamburg)

Biophotometer

(Eppendorf, Hamburg)

DNA Sequencer Modell Megabace 1000

(Amersham, Freiburg)

Microscope BX60

(Olympus, München)

GeneAmp PCR System 9600

(Perkin Elmer, Berlin)

Histocentre 2 embedding machine

(Shandon, Frankfurt aM.)

Microtiterplate-Photometer

(BioRad laboratories, München)

Molecular Imager FX

(BioRad laboratories, München)

Phosphoimager Screen

(BioRad laboratories, München)

Semi-Dry-Blot Fast Blot

(Biometra, Göttingen)

Spectrophotometer Ultraspec 3000

SpeedVac concentrator SVC $100 \mathrm{H}$

(Amersham, Freiburg)

(Schütt, Göttingen)

Thermomixer 5436

(Eppendorf, Hamburg)

Turboblotter $^{\mathrm{TM}}$

(Schleicher \& Schüll, Dassel)

UV Stratalinker $^{\mathrm{TM}} 1800$

(Leica, Nußloch)

X-Ray Automatic Processor Curix 60

(Agfa, München) 


\subsection{Methods}

\subsubsection{Isolation of nucleic acids}

\subsubsection{Isolation of plasmid DNA (Sambrook et al., 1989)}

\subsection{Small-scale isolation of plasmid DNA (Birnboim and Doly, 1979)}

A single E.coli colony was inoculated in $5 \mathrm{ml}$ of LB medium with the appropriate antibiotic and incubated in a shaker for $12-16 \mathrm{hrs}$ at $37^{\circ} \mathrm{C}$ with a speed of $160 \mathrm{rpm} .0 .2$ $\mathrm{ml}$ of this saturated culture was used for making glycerol stocks and rest of the culture was centrifuged at $5000 \mathrm{x} \mathrm{g}$ for $10 \mathrm{~min}$. The pellet was resuspended in $100 \mu \mathrm{l}$ of resuspension solution P1. The bacterial cells were lysed with $200 \mu 1$ of lysis solution P2, incubated at RT for $5 \mathrm{~min}$ and then neutralised with $150 \mu \mathrm{l}$ of neutralisation solution P3. The precipitated solution was incubated at RT for $5 \mathrm{~min}$ and centrifuged at $13000 \mathrm{x} \mathrm{g}$ at RT. The supernatant was transferred into a new tube, and $1 \mathrm{ml}$ of $100 \%$ ethanol was added to precipitate the DNA. It was then stored at $-20^{\circ} \mathrm{C}$ for $30 \mathrm{~min}$, centrifuged at full speed for $20 \mathrm{~min}$, and finally the pellet was washed with $350 \mu \mathrm{l}$ of $70 \%$ ethanol and after air-drying dissolved in $30 \mu \mathrm{l}$ of either $\mathrm{dH}_{2} \mathrm{O}$ or TE buffer.

$\begin{array}{lll}\text { P1: } & 50 \mathrm{mM} & \text { Tris/HCl, } \mathrm{pH} 8.0 \\ & 10 \mathrm{mM} & \text { EDTA } \\ & 100 \mu \mathrm{g} / \mathrm{ml} & \text { RNase A } \\ & & \\ \text { P2: } & 200 \mathrm{mM} & \mathrm{NaOH} \\ & 1 \% & \text { SDS } \\ \text { P3: } & 3.0 \mathrm{M} & \end{array}$




\subsection{Large-scale preparation of Endotoxin free plasmid DNA using the Qiagen Maxi Kit}

A single clone was inoculated in $5 \mathrm{ml}$ LB medium with appropriate antibiotic as a preculture for $6-8 \mathrm{hrs}$ in a $37^{\circ} \mathrm{C}$ shaker. In $100 \mathrm{ml} \mathrm{LB}$ medium with appropriate antibiotic, this pre-culture was added in a dilution of $1 / 500$ fold and incubated overnight at $37^{\circ} \mathrm{C}$ with shaking. The saturated culture was centrifuged at $6000 \mathrm{x} g$ for $15 \mathrm{~min}$. The pellet was resuspended in $5 \mathrm{ml}$ of solution $\mathrm{P} 1$ and cells were lysed with $\mathrm{P} 2$ and $\mathrm{P} 3$ as described above. The precipitated solution was centrifuged at $20000 \mathrm{x}$ g for $30 \mathrm{~min}$ at $4^{\circ} \mathrm{C}$. Meanwhile, the column (Qiagen-tip) that was provided with the midi preparation kit was equilibrated with $10 \mathrm{ml}$ of QBT solution. After centrifugation, the lysate was poured into this equilibrated column to allow the DNA to bind with the resin present in the bed of the column. The column was then washed twice with $10 \mathrm{ml}$ of solution QC. Finally, the DNA was eluted with $5 \mathrm{ml}$ of QF solution. To precipitate the DNA, $3.5 \mathrm{ml}$ of isopropanol was added, mixed thoroughly and then centrifuged at $14000 \mathrm{x}$ g for 30 min at $4^{\circ} \mathrm{C}$. The DNA pellet was washed with $70 \%$ ethanol and dissolved in $100 \mu$ of TE buffer.

\begin{tabular}{|c|c|c|}
\hline \multirow[t]{4}{*}{ QBT: } & $750 \mathrm{mM}$ & Sodium chloride \\
\hline & $50 \mathrm{mM}$ & MOPS pH 7.0 \\
\hline & $15 \%$ & Ethanol \\
\hline & $0.5 \%$ & Triton X-100 \\
\hline \multirow[t]{3}{*}{ QC: } & $1 \mathrm{mM}$ & Sodium chloride \\
\hline & $50 \mathrm{mM}$ & MOPS pH 7.0 \\
\hline & $15 \%$ & Ethanol \\
\hline \multirow[t]{2}{*}{ QF: } & $1.25 \mathrm{M}$ & Sodium chloride \\
\hline & $50 \mathrm{mM}$ & Tris/HCl pH 8.5 \\
\hline
\end{tabular}




\subsubsection{Isolation of genomic DNA}

\subsection{Isolation of genomic DNA from tissue samples with isopropanol}

(Laird et al., 1991)

The method employed was the same as that of Laird et al. (1991). $1 \mathrm{~cm}$ of the tail from a mouse was incubated in $700 \mu \mathrm{l}$ of lysis buffer I containing $35 \mu$ proteinase $\mathrm{K}$ $(10 \mu \mathrm{g} / \mu \mathrm{l})$ at $55^{\circ} \mathrm{C}$ overnight in Thermomixer 5436. The tissue lysate was centrifuged at $14000 \mathrm{x} \mathrm{g}$ for $15 \mathrm{~min}$ and the supernatant was transferred into a new e-cup. After transferring, DNA was precipitated by adding an equal volume of isopropanol and mixed by inverting several times and centrifuged at $14000 \mathrm{x} g$ at RT for $15 \mathrm{~min}$. DNA was washed with $1 \mathrm{ml}$ of $70 \%$ ethanol, dissolved in 80-100 $\mu \mathrm{l}$ of $\mathrm{dH}_{2} \mathrm{O}$ and incubated at $60^{\circ} \mathrm{C}$ for $10 \mathrm{~min}$.

\subsection{Isolation of genomic DNA from cultured cells}

To isolate the DNA from cultured cells, cells were washed with PBS and incubated overnight in $500 \mu \mathrm{l}$ of lysis buffer II at $37^{\circ} \mathrm{C}$. Equal volume of isopropanol was added and mixed by inverting several times followed by incubation for $10 \mathrm{~min}$ at RT, then centrifuged for $15 \mathrm{~min}$ at maximal speed to precipitate the DNA. After washing with $70 \%$ ethanol, the DNA was dissolved in $80 \mu \mathrm{l}$ of $\mathrm{dH}_{2} \mathrm{O}$ and incubated at $60^{\circ} \mathrm{C}$ for 10 $\min$.

\subsubsection{Isolation of total RNA from tissue samples and cultured cells}

Total RNA isolation reagent is an improved version of the single-step method for total RNA isolation. The composition of reagent includes phenol and guanidine thiocyanate in a mono-phase solution. 100-200 $\mathrm{mg}$ of tissue sample was homogenised in 1-2 $\mathrm{ml}$ of TRI Reagent by using a glass-teflon homogeniser. The sample volume should not exceed $10 \%$ of the volume of reagent used for the homogenisation. To isolate total RNA from cultured cells, $350 \mu \mathrm{l}$ of reagent was added to the Petri dish $(6 \mathrm{~cm})$. Cells were homogenised with a rubber stick and the lysate was transferred into a microcentrifuge 
tube. The homogenate was incubated at $4^{\circ} \mathrm{C}$ for $5 \mathrm{~min}$ to permit the complete dissociation of nucleoprotein complexes. Then, $0.2 \mathrm{ml}$ of chloroform was added, mixed vigorously, and stored at $4^{\circ} \mathrm{C}$ for $10 \mathrm{~min}$. After centrifugation at $12000 \mathrm{xg}$ for $15 \mathrm{~min}$ at $4^{\circ} \mathrm{C}$, the colourless upper aqueous phase was transferred into a new tube. The RNA was precipitated by adding $0.5 \mathrm{ml}$ of isopropanol. Finally, the pellet was washed twice with $75 \%$ ethanol and dissolved in 80-100 $\mu 1$ of RNase free water or DEPC-d $\mathrm{H}_{2} \mathrm{O}$.

\title{
2.2.2 Determination of nucleic acid concentration
}

The concentration of nucleic acids was determined spectrophotometrically by measuring absorption of the samples at $260 \mathrm{~nm}$. The quality of nucleic acids i.e. contamination with salt and protein was checked by measurements at 230, 280, and 320 $\mathrm{nm}$. The concentration was calculated according to the formula:$$
C=(E 260-E 320) f c
$$$$
\mathrm{C}=\text { concentration of sample }(\mu \mathrm{g} / \mu \mathrm{l})
$$$$
\text { E } 260=\text { ratio of extinction at } 260 \mathrm{~nm}
$$$$
\text { E } 320=\text { ratio of extinction at } 320 \mathrm{~nm}
$$$$
\mathrm{f} \quad=\text { dilution factor }
$$$$
\text { c = concentration (standard) / absorption (standard) }
$$$$
\text { For double stranded DNA: } \mathrm{c}=0.05 \mu \mathrm{g} / \mu \mathrm{l}
$$$$
\text { for RNA : } \mathrm{c}=0.04 \mu \mathrm{g} / \mu \mathrm{l}
$$$$
\text { for single stranded DNA : } \mathrm{c}=0.03 \mu \mathrm{g} / \mu \mathrm{l}
$$

\subsubsection{Gel electrophoresis}

Gel electrophoresis is the technique by which mixtures of charged macromolecules, especially nucleic acids and proteins, are separated in an electrical field according to their mobility which is directly proportional to macromolecule's charge to mass ratio. 


\subsubsection{Agarose gel electrophoresis of DNA}

Agarose gels are used to electrophorese nucleic acid molecules from as small as 50 bases to more than $20 \mathrm{~kb}$, depending on the concentration of the agarose. Usually, $1 \mathrm{~g}$ of agarose was added to $100 \mathrm{ml}$ of $0.5 \mathrm{x}$ TBE buffer and boiled in the microwave to dissolve the agarose, then cooled down to about $60^{\circ} \mathrm{C}$ before adding $3 \mu \mathrm{l}$ of ethidium bromide $(10 \mathrm{mg} / \mathrm{ml})$. This $1 \%$ agarose gel was poured into a horizontal gel chamber.

\subsubsection{Agarose gel electrophoresis of RNA (Hodge, 1994)}

Single-stranded RNA molecules often have complementary regions that can form secondary structures. Therefore, RNA was run on a denaturing agarose gel that contained formaldehyde, and before loading, the RNA was pre-treated with formaldehyde and formamide to denature the secondary structure of RNA. $1.25 \mathrm{~g}$ of agarose was added to $100 \mathrm{ml}$ of 1 x MOPS Buffer and dissolved by heating in a microwave. After cooling it to about $50^{\circ} \mathrm{C}, 25 \mathrm{ml}$ of formaldehyde (37\%) was added, stirred and poured into a horisontal gel chamber.

RNA samples were treated as follows:

$$
\begin{aligned}
& 10-20 \mu \mathrm{g} \text { RNA } \\
& 10 \times \text { MOPS Buffer } \\
& 3 \mu l \text { Formaldehyde } \\
& 8 \mu l \text { Formamide }(40 \%) \\
& 1.5 \mu l \text { Ethidium bromide }
\end{aligned}
$$

Samples were denaturated at $65^{\circ} \mathrm{C}$ for 10 min and chilled down on ice before loading into the gel. The gel was run at $40 \mathrm{~V}$ at $4^{\circ} \mathrm{C}$ for about $12 \mathrm{hrs}$. 


\subsubsection{SDS-PAGE for the separation of proteins (Laemmli, 1970)}

The NuPAGE® Pre-Cast Gel System (Invitrogen) is a polyacrylamide gel system for high performance gel electrophoresis and is based on SDS-PAGE gel chemistry. It consists of NuPAGE® Bis-Tris Pre-Cast Gels and specially optimised buffers which have an operating $\mathrm{pH}$ of 7.0, giving the system advantages over existing polyacrylamide gel systems with an operating $\mathrm{pH}$ of 8.0. The neutral $\mathrm{pH}$ increases the stability of the proteins and provides better electrophoretic results. To $10 \mu \mathrm{l}$ of whole protein lysate 10 $\mu 1$ of $2 x$ Protein sample buffer was added. The samples were denaturated by boiling in the water bath for $10 \mathrm{~min}$, cooled at RT for $5 \mathrm{~min}$ and loaded in SDS-PAGE (NuPage 4$12 \%$ Bis-Tris gel). The gel electrophoresis was run in 1 x MOPS buffer (Invitrogen). To determine the molecular weight of the proteins on the gel, $10 \mu 1$ of a pre-stained molecular weight standard (See Blue Plus2, Invitrogen) was also loaded. The gel was run at $100 \mathrm{~V}$ for $2 \mathrm{hrs}$ at $\mathrm{RT}$.

\subsubsection{Purification of DNA fragments from agarose gel}

\subsubsection{QIAquick gel extraction method}

This method is designed to extract and purify DNA of $70 \mathrm{bp}$ to $10 \mathrm{~kb}$ in length from agarose gels. Up to $400 \mathrm{mg}$ agarose can be processed per spin column. The principle of this method depends on selective binding of DNA to uniquely designed silica-gel membranes. To the excised DNA fragment from agarose gel, 3 volumes of QG buffer were added and then incubated at $50^{\circ} \mathrm{C}$ for $10 \mathrm{~min}$. After the gel slice was dissolved completely, the solution was applied over a QIAquick column and centrifuged for 1 min. The flow through was discarded and the column was washed with $0.75 \mathrm{ml}$ of PE buffer. After drying the column, it was placed into a fresh microcentrifuge tube. To elute DNA, $50 \mu 1$ of EB buffer was applied to the centre of the QIAquick membrane and centrifuged it for $1 \mathrm{~min}$. 


\title{
2.2.5 Enzymatic modifications of DNA
}

\subsubsection{Restriction of DNA}

Restriction enzyme digestions were performed by incubating double-stranded DNA with an appropriate amount of restriction enzyme in its respective buffer as recommended by the supplier, and at the optimal temperature for the specific enzyme. Standard digestions included 2-10 U enzyme per microgram of DNA. These reactions were usually incubated for 1-3 hrs to ensure complete digestion at the optimal temperature for enzyme activity, which was typically $37^{\circ} \mathrm{C}$. For genomic DNA digestion, the reaction solution was incubated overnight at $37^{\circ} \mathrm{C}$.

\subsubsection{Ligation of DNA fragments}

The ligation of an insert DNA into a vector (digested with appropriate restriction enzyme) was carried out in the following reaction mix:

\author{
30 ng vector DNA (digested) \\ 50-100 ng insert DNA (1:3, vector: insert ratio) \\ $1 \mu 1$ ligation buffer (10x) \\ $1 \mu \mathrm{l} 4$ DNA ligase $(5 \mathrm{U} / \mu \mathrm{l})$ \\ in a total volume of $10 \mu 1$
}

Blunt-end ligations were carried out at $16^{\circ} \mathrm{C}$ for overnight, whereas overhang-end ligations were carried out at room temperature for 2-4 hrs.

\subsubsection{TA-Cloning (Clark, 1988; Hu, 1993)}

Taq polymerase and other DNA polymerases have a terminal transferase activity that results in the non-template addition of a single nucleotide to the $3^{\prime}$ ends of PCR products. In the presence of all 4 dNTPs, dATP is preferentially added. This terminal 
transferase activity is the basis of the TA-cloning strategy. For cloning of PCR products, the pGEMT or pGEMTeasy vector systems that have $5^{6} \mathrm{~T}$ overhangs were used.

The following substances were mixed:

\author{
50 ng of pGEMTeasy vector \\ 150 ng PCR product \\ $1 \mu 1$ of T4 DNA Ligase buffer (x10) \\ $1 \mu l$ of T4 DNA Ligase \\ in a total volume of $10 \mu 1$
}

The substances were mixed by pipetting and incubation was done overnight at $16^{\circ} \mathrm{C}$.

\title{
2.2.6 Preparation of competent E.coli bacteria (Dagert and Ehrlich, 1979)
}

Competent bacterial cells are generated by a physical cell wall modification that facilitates DNA uptake. LB medium (100 ml) was inoculated with a single colony of E.coli (strain $\mathrm{DH} 5 \alpha$ ) and the culture was grown at $37^{\circ} \mathrm{C}$ to $\mathrm{OD}_{600}=0.6$. Bacteria were centrifuged $\left(10 \mathrm{~min}, 4^{\circ} \mathrm{C}, 3000 \mathrm{x} \mathrm{g}\right)$, and the pellet was resuspended in $50 \mathrm{ml}$ of sterile $50 \mathrm{mM} \mathrm{CaCl}_{2}$ solution $\left(4^{\circ} \mathrm{C}\right)$ and incubated on ice for $30 \mathrm{~min}$. The suspension of bacteria was centrifuged $\left(10 \mathrm{~min}, 4^{\circ} \mathrm{C}, 3000 \mathrm{xg}\right)$ and the pellet was resuspended in $10 \mathrm{ml}$ of sterile $50 \mathrm{mM} \mathrm{CaCl} 2\left(4^{\circ} \mathrm{C}\right)$ with $15 \%$ glycerol. The mixture was dispensed into aliquots of $100 \mu 1$ and stored at $-80^{\circ} \mathrm{C}$. Mostly, competent DH5 $\alpha$ were purchased from Invitrogen.

\subsubsection{Transformation of competent bacteria (Ausubel et al., 1994)}

Transformation of bacteria was done by gently mixing one aliquot of competent bacteria $(50 \mu \mathrm{l})$ with $5-10 \mu \mathrm{l}$ of ligation reaction. After incubation for $30 \mathrm{~min}$ on ice, bacteria were heat shocked for $45 \mathrm{sec}$ at $37^{\circ} \mathrm{C}$ or $42^{\circ} \mathrm{C}$, cooled down for 2 min on ice. After adding 450-900 $\mu 1$ of LB medium, bacteria were incubated at $37^{\circ} \mathrm{C}, 200 \mathrm{rpm}, 1 \mathrm{hr}$, to allow recovery of heat shocked bacteria which were then plated out on LB-agar plates. 


\subsubsection{Polymerase Chain Reaction (PCR)}

The polymerase chain reaction (PCR) represents an important technique in the field of molecular biology. It is a very sensitive, powerful technique (Saiki et al., 1988) and widely used for the exponential amplification of specific DNA sequences in vitro by using sequence specific synthetic oligonucleotides (primers). The general principle of PCR starts from a pair of oligonucleotide primers that are designed so that a forward or sense primer directs the synthesis of DNA towards a reverse or antisense primer, and vice versa. During the PCR, the Taq DNA polymerase (a heat stable polymerase) (Chien et al., 1976) catalyses the synthesis of a new DNA strand that is complementary to a template DNA from the 5' to 3' direction by a primer extension reaction, resulting in the production of the DNA region flanked by the two primers. It allows the rapid and unlimited amplification of specific nucleic acid sequences that may be present at very low concentrations in very complex mixtures.

\subsubsection{PCR amplification of DNA fragments}

The amplification cycles were performed in an automatic thermocycler. In general, the PCR reaction contains the following substances:

\begin{tabular}{|c|c|}
\hline $10 \mathrm{ng}$ & DNA \\
\hline $1 \mu 1$ & forward primer (10 pmol) \\
\hline $1 \mu l$ & reverse primer $(10 \mathrm{pmol})$ \\
\hline $1 \mu l$ & $10 \mathrm{mM}$ dNTPs \\
\hline $5 \mu l$ & $10 \times$ PCR buffer \\
\hline $1.5 \mu 1$ & $50 \mathrm{mM} \mathrm{MgCl} 2$ \\
\hline $0.5 \mu \mathrm{l}$ & Taq DNA Polymerase (5 U/ $\mu \mathrm{l})$ \\
\hline Up to $50 \mu 1$ & $\mathrm{dH}_{2} \mathrm{O}$ \\
\hline
\end{tabular}


The reaction mixture was placed in a $200 \mu 1$ reaction tube and placed in a thermocycler. Thermal cycling was carried out for 35 cycles with denaturation at $97^{\circ} \mathrm{C}$ for $30 \mathrm{sec}$, annealing at $55-60^{\circ} \mathrm{C}$ for $30 \mathrm{sec}$ and extension at $72^{\circ} \mathrm{C}$ for $1 \mathrm{~min}$.

\subsubsection{Reverse transcription PCR (RT-PCR)}

RT-PCR generates cDNA fragments from RNA templates and is very useful to determine the expression of genes in specific tissues or in different development stages. 1-5 $\mu \mathrm{g}$ of total RNA was mixed with $1 \mu \mathrm{l}$ of oligo $(\mathrm{dT})_{18}$ primer $(10 \mathrm{pmol} / \mu \mathrm{l})$ in a total volume of $12 \mu \mathrm{l}$. To avoid the possible secondary structure of the RNA, which might interfere with the synthesis, the mixture was heated to $70^{\circ} \mathrm{C}$ for $10 \mathrm{~min}$, and then quickly chilled on ice. After a brief centrifugation, the following substances were added to the mixture:

$$
\begin{aligned}
& 4 \mu \mathrm{l} 5 \text { first strand buffer } \\
& 2 \mu 10.1 \text { M DTT } \\
& 1 \mu 110 \mathrm{mM} \text { dNTPs } \\
& 1 \mu \mathrm{RNasin}(10 \mathrm{U} / \mu \mathrm{l})
\end{aligned}
$$

The content of the tube was mixed gently and incubated at $42^{\circ} \mathrm{C}$ for $2 \mathrm{~min}$. Then, $1 \mu 1$ of reverse transcriptase enzyme (Superscript II) was added and incubated at $42^{\circ} \mathrm{C}$ for 50 min for the first strand cDNA synthesis. Next, the reaction was inactivated by heating at $70^{\circ} \mathrm{C}$ for $15 \mathrm{~min} .1 \mu \mathrm{l}$ of the first strand reaction was used for the PCR reaction. 


\subsubsection{One-Step RT-PCR}

To obtain specific RT-PCR products, the QIAGEN OneStep RT-PCR kit was employed which contains optimised components that allow both reverse transcription and PCR amplification to take place in what is commonly referred to as a "one-step" reaction.

Master mix:

5 x Qiagen OneStep RT-PCR buffer

dNTP mix (containing $10 \mathrm{mM}$ of each dNTP)

Forward primer (10 pmol)

Reverse primer (10 pmol)

Qiagen OneStep RT-PCR Enzyme Mix

RNase inhibitor (20 units per $1 \mu \mathrm{l}$ )

RNase-free water
Per reaction:

$10 \mu 1$

$2 \mu 1$

$1 \mu 1$

$1 \mu 1$

$2 \mu 1$

$1 \mu 1$

$31 \mu 1$

$2 \mu \mathrm{l}(2 \mu \mathrm{g})$ of total RNA isolated from mouse tissues was added to $48 \mu \mathrm{l}$ of prepared Master mix in a PCR tube. The sample was placed in the thermal cycler and the RT-PCR program was followed according to the user manual. Reverse transcription reaction was performed at $50^{\circ} \mathrm{C}$ for $30 \mathrm{~min}$. To denaturate the DNA-RNA hybrid molecules, the reaction was heated to $94^{\circ} \mathrm{C}$ for $10 \mathrm{~min}$. Thermal cycling was carried out for 35 cycles with denaturation at $94^{\circ} \mathrm{C}$ for $30 \mathrm{sec}$, annealing at $56-60^{\circ} \mathrm{C}$ for $40 \mathrm{sec}$ and extension at $72^{\circ} \mathrm{C}$ for $1 \mathrm{~min}$.

\subsubsection{Protein methods}

\subsubsection{Isolation of total protein}

$100 \mathrm{mg}$ of tissue was homogenised in $500 \mu \mathrm{l}$ lysis buffer A with a Teflon-glass headed pestle. Then, homogenised samples were handled with ultrasound on ice $2 \times 2$ min. The samples were centrifuged at $8000 \mathrm{x}$ g for $20 \mathrm{~min}$ at $4^{\circ} \mathrm{C}$ and the supernatant was aliquoted in several microcentrifuge tubes. The tubes were frozen in liquid nitrogen and 
stored at $-80^{\circ} \mathrm{C} .5 \times 10^{6}$ cells $/ \mathrm{ml}$ were washed with cold phosphate buffered saline and resuspended in $50 \mu \mathrm{l}$ of lysis buffer B. The cells were allowed to swell on ice for 30 min, after which the cells were resuspended in $300 \mu$ of lysis buffer B. After homogenisation, samples were handled with ultrasound on ice 2 x $30 \mathrm{sec}$ and centrifuged at $24000 \mathrm{x} \mathrm{g}$ for $20 \mathrm{~min}$ at $4^{\circ} \mathrm{C}$. The protein extract was either used immediately or stored at $-80^{\circ} \mathrm{C}$ for later use.

\subsubsection{Determination of protein concentration (Bradford, 1976)}

To determine the protein concentration, Bio-Rad protein assay was employed which is a dye-binding assay based on the differential color change of a dye in response to various concentrations of protein. The assay is based on the observation that the absorbance maximum for an acidic solution of Coomassie Blue G-250 shifts from 494 to $595 \mathrm{~nm}$ when the binding to protein occurs. The BSA stock solution of $1 \mathrm{mg} / \mathrm{ml}$ was diluted in order to obtain standard dilutions in range of $10 \mu \mathrm{g} / \mathrm{ml}$ to $100 \mu \mathrm{g} / \mathrm{ml}$. The Bio-Rad's color reagent was diluted 1:5 with $\mathrm{H}_{2} \mathrm{O}$ and filtered through $0.45 \mu \mathrm{m}$ filter. In a 96-well microtiter plate, $20 \mu \mathrm{l}$ of each standard dilution and the samples to be measured were pipetted with $280 \mu \mathrm{l}$ of the color reagent. The absorption of the color reaction was measured at $595 \mathrm{~nm}$ in a microplate reader (Microplate Reader 450, Bio-Rad).

\subsubsection{Blotting techniques}

\subsubsection{Southern blotting of DNA onto nitrocellulose filter (Southern, 1975)}

In Southern blotting, the transfer of denaturated DNA from agarose gels onto nitrocellulose membrane is achieved by capillary flow. 20 x SSC buffer, in which nucleic acids are highly soluble, is drawn up through the gel onto nitrocellulose membrane, taking with it the single-stranded DNA that becomes immobilised in the membrane matrix.

After electrophoresis of DNA, the gel was treated with $0.25 \mathrm{M} \mathrm{HCl}$ for depurination. It was followed by denaturation solution for $30 \mathrm{~min}$ and $45 \mathrm{~min}$ in neutralisation solution. The transfer of the DNA to the nitrocellulose membrane was done in a Turbo-Blot- 
apparatus (Schleicher \& Schuell, Dassel). About 25-28 Whatman filter papers (GB 003) were layered on a Stack Tray, followed by 4 Whatman filter papers (GB 002) and 1 Whatman filter paper (GB 002) soaked with 20 x SSC. The equilibrated nitrocellulose filter that was also soaked with $20 \mathrm{x}$ SSC was laid on the top. The agarose gel which was treated as described above, was placed on the filter and was covered with 3 Whatman filter papers GB 002 soaked with $20 \mathrm{x}$ SSC. The buffer tray was placed and filled with 20 x SSC. Finally a wick, which was soaked with $20 \times$ SSC, and the wick cover were put on top of the blot. The transfer was carried out for overnight. Finally, after disassembling of the blot, the filter was washed briefly in $2 \times$ SSC and the DNA was fixed onto the filter by either baking it at $80^{\circ} \mathrm{C}$ for at last $2 \mathrm{hrs}$ or by UVcrosslinking in UV Stratalinker 1800.

\subsubsection{Northern blotting of RNA onto nitrocellulose filter}

For the transfer of RNA onto a nitrocellulose filter, the same procedure as described above (2.2.10.1) was performed. In this case, however, the gel does not need to be denaturated, but was transferred directly onto the filter.

\subsubsection{Western blotting of protein onto PVDF membrane \\ (Gershoni and Palade, 1982)}

\begin{tabular}{|c|c|}
\hline \multirow[t]{2}{*}{ Anode buffer I } & 0.3 M Tris/HCl, $\mathrm{pH} 10.4$ \\
\hline & 20\% Methanol \\
\hline \multirow[t]{2}{*}{ Anode buffer II } & 25 mM Tris/HCl, pH 10.4 \\
\hline & 20\% Methanol \\
\hline \multirow[t]{3}{*}{ Cathode buffer } & $40 \mathrm{mM} \varepsilon$-Aminocaproic acid \\
\hline & 25 mM Tris/HCl, pH 9.4 \\
\hline & $20 \%$ Methanol \\
\hline
\end{tabular}


After electrophoresis of proteins on a SDS-PAGE, the gel and the PVDF membrane, which were cut at the size of the gel, were first moistened with methanol and then equilibrated in anode buffer II. Six pieces of GB004 Whatman filter paper were also cut at the size of the gel. Two pieces of filter paper were soaked in anode buffer I and one paper in anode buffer II. First, the papers soaked with anode buffer I were placed on the semi dry transfer machine's lower plate and then papers soaked with anode buffer II were placed over it. The equilibrated membrane was placed over them and then the gel was placed avoiding any air bubbles. Another three Whatman papers soaked with cathode buffer were placed over to complete the sandwich model. The upper plate was placed over this sandwich and the transfer was carried out at $3.5 \mathrm{~mA} / \mathrm{cm}^{2}$ for $1 \mathrm{hr}$.

\section{Membrane staining}

Membrane was stained with Coomassie blue for $30 \mathrm{~min}$ at RT.

Coomassie blue: $\quad 0.1 \%$ Coomassie 90\% Methanol $10 \% \mathrm{CH}_{2} \mathrm{COOH}$

Destaining of the membrane

Destaining solution: $40 \%$ Methanol $10 \% \mathrm{CH}_{2} \mathrm{COOH}$ up to $\mathrm{H}_{2} \mathrm{O}$

\subsubsection{1 "Random Prime" method for generation of ${ }^{32} \mathrm{P}$ labeled DNA (Denhardt, 1966; Feinberg and Vogelstein, 1984)}

Rediprime $^{\mathrm{TM}}$ II Random Prime Labeling System (Amersham Pharmacia) was used for labelling of DNA probes. The method depends on the random priming principle developed by Feinberg and Vogelstein (1984). The reaction mix contained dATP, dGTP, dTTP, Klenow fragment (4-8 U) and random oligodeoxyribonucleotides. Firstly, 25-50 ng of DNA were denaturated in a total volume of $46 \mu \mathrm{l}$ at boiling water for 10 min and quick chilled on ice for $5 \mathrm{~min}$. After pipetting the denaturated probe in Rediprime $^{\mathrm{TM}}$ II Random Prime Labelling System cup, $4 \mu \mathrm{l}$ of $\left[\alpha-{ }^{32} \mathrm{P}\right] \mathrm{dCTP}$ (3000 $\mathrm{Ci} / \mathrm{mmol}$ ) was added to the reaction mixture. The labelling reaction was carried out at 
$37^{\circ} \mathrm{C}$ for $1 \mathrm{hr}$. The labelled probe was purified from uncorporated $\left[\alpha-{ }^{32} \mathrm{P}\right] \mathrm{dCTP}$ by using microspin columns (Amersham Pharmacia).

\subsubsection{Non-radioactive dye terminator cycle sequencing}

Non-radioactive sequencing was performed with the Dye Terminator Cycle Sequencing-Kit (ABI PRISM). The reaction products were analysed with automatic sequencing equipment, MegaBase DNA Sequencer. For the sequencing reaction, four different dye labelled dideoxy nucleotides were used (Sanger et al., 1977), which, when exposed to an argon laser, emit fluorescent light which can be detected and interpreted. The reaction was carried out in a total volume of $10 \mu \mathrm{l}$ containing $1 \mu \mathrm{g}$ plasmid DNA or 100-200 ng purified PCR products, 10 pmol primer and $4 \mu$ reaction mix (contains dNTPs, dideoxy dye terminators and Taq DNA polymerase). Elongation and chain termination take place during the following program in a thermocycler: $4 \mathrm{~min}$ denaturation followed by 25 cycles at $95^{\circ} \mathrm{C}, 30 \mathrm{sec} ; 55^{\circ} \mathrm{C}, 15 \mathrm{sec}$, annealing; $60^{\circ} \mathrm{C}, 4$ min, elongation. After the sequencing reaction, the DNA was precipitated with $1 / 10$ volume $3 \mathrm{M}$ sodium acetate and 2.5 volume $100 \%$ ethanol and washed in $70 \%$ ethanol. The pellet was dissolved in $4 \mu \mathrm{l}$ of loading buffer, denaturated at $95^{\circ} \mathrm{C}$ for $3 \mathrm{~min}$, and finally loaded on the sequence gel.

\subsubsection{Hybridisation of nucleic acids (Denhardt, 1966)}

The membrane to be hybridised was equilibrated in $2 \times \mathrm{SSC}$ and transferred to a hybridisation bottle. After adding $10 \mathrm{ml}$ of hybridisation solution and sheared denaturated salmon DNA, the membrane was incubated for $2 \mathrm{hrs}$ in the hybridisation oven at an appropriate temperature, which is usually $65^{\circ} \mathrm{C}$. Then, the labelled probe was denaturated at $95^{\circ} \mathrm{C}$ for $10 \mathrm{~min}$, chilled on ice for $5 \mathrm{~min}$, and then added to the hybridisation solution. The hybridisation was carried out overnight in the oven. Next day, the filter was washed for 10 min with $2 \times$ SSC containing $0.2 \%$ SDS at $65^{\circ} \mathrm{C}$. Finally, the membrane was washed with $0.2 \times$ SSC containing $0.1 \%$ SDS at the hybridisation temperature. After drying the filter, it was sealed in Saran wrap and exposed to autoradiography overnight at $-80^{\circ} \mathrm{C}$ or to Phosphoimager screen for 1-4 hrs. 
The film was developed in X-Ray Automatic Processor Curix 60 or the screen was scanned in Phosphoimager. For quantification of detected bands, the program Quantity One (Bio-Rad) was used.

\subsubsection{Histological techniques}

\subsubsection{Tissue preparation for paraffin-embedding}

The freshly prepared tissues were fixed in Bouin's solution or $4 \%(\mathrm{w} / \mathrm{v})$ paraformaldehyde for $24 \mathrm{hrs}$ to prevent alterations in the cellular structure. The tissue to be embedded in paraffin should be free of water. The dehydration process was accomplished by passing the tissue through a series of increasing alcohol concentrations. For this purpose, the tissue was let in $30 \%, 70 \%, 90 \%$, and $100 \%(2 \mathrm{x})$ ethanol for $1 \mathrm{hr}$ at RT. Later, the alcohol was removed from the tissue by incubating it in methylbenzoat for overnight. It was then incubated in $5 \mathrm{ml}$ of histoclear (Xylol) for 10$30 \mathrm{~min}$ at RT. The second histoclear was not discarded but $5 \mathrm{ml}$ of paraplast were added and the incubation was continued at $60^{\circ} \mathrm{C}$ for another $30 \mathrm{~min}$. The histoclear and paraffin mixture was discarded and the tissue was further incubated in $5 \mathrm{ml}$ of paraplast at $60^{\circ} \mathrm{C}$ for overnight. Before embedding, the paraffin was changed at least three times. Finally, the tissue was placed in embedding mold and melted paraffin was poured into the mold to form a block. The block was allowed to cool and was then ready for sectioning.

\subsubsection{Sections of the paraffin block}

The paraffin blocks were pre-cut to the optimal size and clamped into the microtome (Hn 40 Ing., Nut hole, Germany). The cut-thickness of the section was $5 \mu \mathrm{m}$. The sections were floated on $40^{\circ} \mathrm{C}$ water to allow actual spread and subsequently put onto pre-treated slides. In order to achieve a better adhesion of the sections, the slides were treated with a drop of serum-formalin. A fine brush was used to transfer the sections to the pre-treated slides. After complete evaporation at $37^{\circ} \mathrm{C}$ for $2-5$ days, slides were stored at $4^{\circ} \mathrm{C}$ for further analysis. 


\subsubsection{Immunofluorescence staining of mouse tissues}

Fixation and subsequent treatment of mouse tissue were performed as described in section 2.2.14.1. Tissue sections were incubated twice for $10 \mathrm{~min}$ in Roticlear to remove the paraffin. Then, sections were re-hydrated in a decreasing ethanol series $(100 \%$, $96 \%, 70 \%, 50 \%$, and $30 \%$ ) for 2 min each.

For immunofluorescence staining, sections were washed in PBS and then incubated with a blocking solution containing $10 \%$ goat serum and $0.02 \%$ Tween-20 in PBS for 1 $\mathrm{hr}$ at RT. The sections were incubated with primary antibodies for overnight in a humidified chamber at $4^{\circ} \mathrm{C}$. Tissue sections were rinsed three times for $5 \mathrm{~min}$ in PBS and subsequently incubated with appropriate secondary antibody for $1 \mathrm{hr}$ in a humidified chamber at RT. Finally, sections were washed three times for $5 \mathrm{~min}$ in PBS and the nuclei were counterstained with DAPI. Immunostaining of the sections was examined using a fluorescence equipped microscope (BX60; Olympus).

\subsubsection{Immunofluorescence staining of cells}

Cells were fixed in $4 \%$ paraformaldehyde in PBS for $20 \mathrm{~min}$ at $4^{\circ} \mathrm{C}$, followed by $100 \%$ methanol at $-20^{\circ} \mathrm{C}$ for $5 \mathrm{~min}$. The cells were rinsed in PBS. An initial blocking step was performed with the blocking solution (2\% horse serum and $0.5 \%$ Triton X-100 in PBS) for $1 \mathrm{hr}$. The primary antibody with appropriate dilution was applied for overnight at $4^{\circ} \mathrm{C}$. Cells were subsequently incubated with $\mathrm{Cy} 3$ - conjugated mouse anti-goat IgG for $1 \mathrm{hr}$ at RT. One drop of mounting medium with DAPI was dispensed onto the slides after washing with PBS. Fluorescent cells were visualised with Olympus BX60 microscope using $20 \mathrm{X}$ or $60 \mathrm{X}$ Neofluor lens, photographed using digital camera and analysed by analysis 3.0 soft imaging system. 


\subsubsection{Hematoxylin-eosin (H\&E) staining of the histological sections}

Tissue sections were first incubated three times in xylene for $3 \mathrm{~min}$ each, followed by incubation three times in $100 \%$ for $3 \mathrm{~min}, 95 \%$ and $80 \%$ ethanol for $2 \mathrm{~min}$ each. Thereafter slides were washed in $\mathrm{dH}_{2} \mathrm{O}$ for $5 \mathrm{~min}$ and stained for $3 \mathrm{~min}$ in hematoxylin. This staining was followed by rinsing with deionised water and washing in tap water for $5 \mathrm{~min}$. The treated slides were dipped fast in acid ethanol $(1 \mathrm{ml}$ concentrated $\mathrm{HCl}$ in 400 $\mathrm{ml} \mathrm{70 \%} \mathrm{ethanol)} \mathrm{for} \mathrm{8-12} \mathrm{times} \mathrm{to} \mathrm{destain,} \mathrm{rinsed} \mathrm{in} \mathrm{tap} \mathrm{water} \mathrm{for} 2 \mathrm{~min}$ and in deionised water for $2 \mathrm{~min}$, stained in eosin for $15 \mathrm{sec}$ and then incubated three times in $95 \%$ and $100 \%$ ethanol for $5 \mathrm{~min}$ each. Finally, the stained slides were incubated three times in xylene for 15 min and mounted with Eukitt-quick hardening mounting medium.

\subsubsection{Generation of polyclonal antibody}

\subsubsection{Generation of Pelo-GST fusion construct}

Pelota cDNA fragment containing the coding sequence was amplified using primers with 5' overhang restriction sites sequences (Pelo pET-F and Pelo pET-R). PCR was performed using PfuI DNA polymerase (Promega) with proof-reading activity to avoid mismatches in amplified Pelota sequence.

PCR condition was as follows:

\begin{tabular}{|c|c|c|}
\hline $94{ }^{\circ} \mathrm{C}$ & $5 \mathrm{~min}$ & \\
\hline $94^{\circ} \mathrm{C}$ & $1 \mathrm{~min}$ & \\
\hline $60^{\circ} \mathrm{C}$ & $1 \mathrm{~min}$ & 35 cycles \\
\hline $72^{\circ} \mathrm{C}$ & $1 \mathrm{~min}$ & \\
\hline $72^{\circ} \mathrm{C}$ & $10 \mathrm{~min}$ & \\
\hline
\end{tabular}

$1.1 \mathrm{~kb}$ PCR product was digested with EcoRI and XhoI enzymes, purified from a 1\% agarose gel, ligated into pET41a expression vector and then construct was transformed into competent E.coli DH5 $\alpha$ cells. 


\subsubsection{Expression of recombinant proteins in the $\mathrm{pET}$ vector}

The recombinant pET41a construct was transformed into the host bacterial strain E.coli BL-21 (DE3). The BL-21 strain (Novagen) is lysogenic for a prophage that contains an IPTG inducible T7 RNA polymerase. A single colony was picked from a freshly streaked plate into $50 \mathrm{ml}$ of LB culture medium containing kanamycin and incubated for overnight culture at $37^{\circ} \mathrm{C}$. Overnight culture was diluted into $500 \mathrm{ml}$ fresh LB medium and cultured further at $37^{\circ} \mathrm{C}$ until $\mathrm{OD} 600$ reached 0.6-0.8. A non-induced sample was collected as a control. Induction was performed by adding IPTG to a final concentration of $1 \mathrm{mM}$ and cultured for $4 \mathrm{hrs}$. Finally, the bacterial cells were harvested by centrifugation at $5000 \mathrm{x}$ g for $10 \mathrm{~min}$ at $4^{\circ} \mathrm{C}$ and frozen at $-80^{\circ} \mathrm{C}$.

\subsubsection{Purification of GST fusion proteins}

The pellet of bacterial cells was resuspended in $10 \mathrm{ml}$ of lysis buffer $(\mathrm{pH} \mathrm{8.0)}$ and sonicated on ice. The cell debris from protein extract was removed by centrifugation for $20 \mathrm{~min}$ at $10000 \mathrm{xg}, 4^{\circ} \mathrm{C}$. The supernatant was filtrated through $0.45 \mu \mathrm{m}$ filter and incubated with preequilibrated glutathione-agarose (Sigma) for $1 \mathrm{hr}$ at $4{ }^{\circ} \mathrm{C}$ with gentle mixing. The bound resin was washed four times with PBT at $4^{\circ} \mathrm{C}$. Thereafter fusion protein was eluted with $3 \mathrm{ml}$ elution buffer $(10 \mathrm{mM}$ reduced glutathione in $50 \mathrm{mM}$ Tris/HCl, $\mathrm{pH}$ 7.5). Purified protein was dialysed overnight at $4^{\circ} \mathrm{C}$ against PBS. Protein quality and quantity were checked by SDS-PAGE and Western blotting.

\subsubsection{Immunisation of rabbits}

Two rabbits were immunised each with $500 \mu \mathrm{g}$ of GST-Pelo fusion protein mixed with Freund's complete adjuvant in 1:1 ratio. Before injection, preimmune sera were collected from the animals. First booster immunisation was performed 14 days after first injection with 1:1 ratio of antigen with Freund's incomplete adjuvant. Second booster was given 28 days and a third booster 56 days after the first immunisation. Final 
bleeding was done 70 days after the first immunisation. The antiserum was aliquoted and stored at $-80^{\circ} \mathrm{C}$.

\subsubsection{Affinity purification of polyclonal antibody}

For affinity purification of the antibody, HiTrap NHS-activated $1 \mathrm{ml}$ columns (Amersham) were used. The columns are made of medical grade polypropylene, which is biocompatible and non interactive with biomolecules. NHS-Activated Sepharose is designed for the covalent coupling of ligands containing primary amino group. Nonspecific adsorption of proteins to HiTrap columns is negligible due to the hydrophilic properties of the base matrix. The activated gel is supplied in $100 \%$ isopropanol to preserve the stability of the activated gel prior to coupling.

\section{Ligand coupling}

Coupling buffer: $\quad 0.2 \mathrm{M} \mathrm{NaHCO} 3$

$$
0.5 \mathrm{M} \mathrm{NaCl}(\mathrm{pH} 8.3)
$$

Pelo-GST fusion protein (1 mg) was dialysed overnight against coupling buffer. Isopropanol present in column was washed with $1 \mathrm{M} \mathrm{HCl}$ (ice cold). The flow rate during the pumping was adjusted to about $1 \mathrm{ml} / \mathrm{min}$. Immediately after washing, $1 \mathrm{ml}$ of the ligand solution was injected onto the column, then the column was sealed and let it stand for $4 \mathrm{hrs}$ at $4^{\circ} \mathrm{C}$.

\section{Washing and deactivation}

Buffer A: 0.5 M Ethanolamine, 0.5 M NaCl (pH 8.3)

Buffer B: $0.1 \mathrm{M}$ Acetate, $0.5 \mathrm{M} \mathrm{NaCl}(\mathrm{pH} 4.0)$

A series of alternate washings (3 x $2 \mathrm{ml})$ with buffer A and buffer B was done. Finally, the column was washed with $2 \mathrm{ml}$ of PBS. 


\section{Affinity purification of antiserum}

The column was equilibrated with 10 column volumes of start buffer (PBS). The antiserum was diluted two times with PBS and filtered through a $0.45 \mu \mathrm{m}$ filter and then applied onto the column. During pumping, a constant flow rate of $0.5 \mathrm{ml} / \mathrm{min}$ was maintained. The column was washed with 10 column volumes of PBS. Elution was done with three volumes of $100 \mathrm{mM}$ glycin/ $\mathrm{HCl}(\mathrm{pH}$ 2.7). Eluted antibody fractions were neutralised by adding $3.5 \mu 1$ of $1 \mathrm{M}$ Tris/ $\mathrm{HCl}(\mathrm{pH} 7.5)$. The purified antibody fraction was desalted by dialysis against PBS. The column was re-equilibrated with 10 volumes of PBS. The antiserum solution was recovered from the dialysis tubing and concentrated using Centrisart columns to about $0.5 \mathrm{ml}$.

\subsubsection{Protein G purification of antibody}

Protein G sepharose beads (Santa Cruz) were equilibrated by washing five times in binding buffer $(20 \mathrm{mM}$ sodium phosphate buffer, $\mathrm{pH} 7.0,0.15 \mathrm{M} \mathrm{NaCl})$. Antiserum diluted in ratio 1:1 with binding buffer was mixed with protein $G$ sepharose and incubated at RT for $1.5 \mathrm{hrs}$. After brief centrifugation step, the supernatant was removed and protein $\mathrm{G}$ was washed four times with binding buffer. Elution was done with four protein $\mathrm{G}$ volumes of elution buffer $(100 \mathrm{mM}$ glycin/ $\mathrm{HCl}, \mathrm{pH} 2.7)$. Eluted antibody fractions were neutralised by adding $3.5 \mu \mathrm{l}$ of $1 \mathrm{M}$ Tris/ $\mathrm{HCl}(\mathrm{pH} 7.5)$. Finally, antibody was dialysed overnight against PBS.

\subsubsection{Eukaryotic cell culture methods}

\subsubsection{Cell culture conditions}

NIH $3 \mathrm{~T} 3$ and HeLa cells were grown in DMEM medium with L-glutamin containing $10 \% \mathrm{FBS}$ and $1 \%$ penicillin/streptomycin solution. The cells were cultured at $37^{\circ} \mathrm{C}$ in a humidified incubator with $5 \% \mathrm{CO}_{2}$. 


\subsubsection{Trypsinisation of eukaryotic cells}

Cells were washed twice with sterile PBS and incubated in minimal amount trypsinEDTA (0.5 g/l trypsin, $0.2 \mathrm{~g} / 1$ EDTA) at $37^{\circ} \mathrm{C}$ until they had detached from the dish. The process was controlled under an inverted microscope. Trypsin was inhibited by addition of growth medium in which the cells were subsequently resuspended. The trypsin was removed by centrifugation at $2000 \mathrm{x}$ g for $3 \mathrm{~min}$. Cells were resuspended in an appropriate volume of cell culture medium and transferred into a new flask with medium.

\subsubsection{Cryopreservation and thawing of eukaryotic cells}

Trypsinised cells were spun down (1000 x g for $5 \mathrm{~min})$ in $4 \mathrm{ml}$ of growth medium. The supernatant was aspirated and the cells were resuspended in freezing medium (DMEM, $20 \% \mathrm{FCS}, 10 \% \mathrm{DMSO})$. Aliquots of the cells were kept for 2 days at $-80^{\circ} \mathrm{C}$ and then stored in liquid nitrogen. For revitalisation, frozen cells were quickly thawed and cells were inoculated in a suitable amount of growth medium.

\subsubsection{Isolation and handling of primary mouse embryonic fibroblasts (MEFs)}

In order to isolate MEFs, pregnant female mice were sacrificed at 13-14 p.c. by cervical dislocation. Dissect out the uterine horns, briefly rinse them in $70 \%(\mathrm{v} / \mathrm{v})$ ethanol and place into a Petri dish containing PBS. Then separate each embryo from its placenta and surrounding membranes. Cut away brain for genotyping and remove dark red organs and as much blood as possible, wash with fresh PBS and finely mince the embryos until they become "pipettable". Suspend cells/tissue in several $\mathrm{ml}$ of trypsin-EDTA (1-2ml per embryo) and incubate with gentle shaking at $37^{\circ} \mathrm{C}$ for $5-10$ min together with a few $5 \mathrm{~mm}$ glass beads. Ideally, the resulting cell suspension should be essentianly free of any larger pieces of tissue and should not be too viscous (genomic DNA-lysed cells). Transfer the suspension to $10 \mathrm{ml}$ falcon tube and add about 2 volumes of fresh medium, 
then resuspend it followed by cenrifugation at $1000 \mathrm{x}$ g for $5 \mathrm{~min}$ and plate it out at 1 embryo equivalent per $10 \mathrm{~cm}$ dish. Change medium on the following day.

\subsubsection{Karyotype analysis}

After culturing of blastocyst for $48-72 \mathrm{hrs}, 3 \mu \mathrm{l}$ Nocodazol $(1 \mu \mathrm{g} / \mathrm{ml})$ was added to $30 \mu \mathrm{l}$ of culture medium and cells were further incubated for $6 \mathrm{hrs}$ at $37^{\circ} \mathrm{C}$ in $5 \% \mathrm{CO}_{2}$. Cells were washed twice with PBS, trypsinised with $0.5 \mathrm{~g} / 1$ trypsin and incubated at $37^{\circ} \mathrm{C}, 5 \%$ $\mathrm{CO}_{2}$ for 5 min. Trypsin was inactivated with $150 \mu \mathrm{l}$ of ES cell medium. Cells were resuspended two times with a micropipette, transferred in an Eppendorf tube and centrifuged at $250 \mathrm{x}$ g for $5 \mathrm{~min}$. After resuspension in $100 \mu \mathrm{l}$ of $75 \mathrm{mM} \mathrm{KCl}(0.563 \%)$ cells were incubated for $20 \mathrm{~min}$ at $37^{\circ} \mathrm{C}$ and then centrifuged at $500 \mathrm{x}$ g for $5 \mathrm{~min}$. After removing of the $\mathrm{KCl}$, cells were fixed in $100 \mu$ ice cold methanol/acetic acid 3:1 $\left(\mathrm{Vol} / \mathrm{Vol}\right.$ ) for $10 \mathrm{~min}$ at $4^{\circ} \mathrm{C}$ and centrifuged at $650 \mathrm{x}$ g for $5 \mathrm{~min}$. Fixation step was repeated. Finally, cells were resuspended in $15 \mu \mathrm{l}$ of fixative solution and dropped onto prewarmed $\left(37^{\circ} \mathrm{C}\right)$ glass slides. Slides were stained with Giemsa $(5 \%$ Giemsa in PBS buffer) for $10 \mathrm{~min}$ and washed under running tap water for $3 \mathrm{~min}$.

\subsubsection{Transfection of mammalian cells}

The transfection involves the introduction of foreign DNA into mammalian cells for its expression. The reagent used in this study was "Lipofectamine 2000 TM" (Invitrogen, Karlsruhe, Germany). For transfection, approximately, $0.5 \times 10^{6} \mathrm{HeLa}$ cells were plated in small flasks with $5 \mathrm{ml}$ of complete DMEM and incubated overnight at $37^{\circ} \mathrm{C}, 5 \%$ $\mathrm{CO}_{2}$. $12 \mu \mathrm{l}$ of Lipofectamine $2000 \mathrm{TM}$ reagent and $4 \mu \mathrm{g}$ of the DNA of interest were diluted each in a total volume of $100 \mu 1$, respectively, with OptiMEM I reduced serum medium (Invitrogen, Karlsruhe, Germany) and incubated at RT for $10 \mathrm{~min}$. Subsequently mixed them together in a reaction tube and then incubated at RT for 30 min. The DMEM containing cells were washed with PBS and the medium was replaced with $1 \mathrm{ml}$ of OptiMEM I medium without antibiotics/FCS.

The reaction mixture was added in the flask drop-by-drop and incubated for 2.5-3 hrs at $37^{\circ} \mathrm{C}$, followed by adding $1 \mathrm{ml}$ of OptiMEM I medium with $20 \%$ FCS and incubated for 
next $3 \mathrm{hrs}$, then replaced transfection reagent with DMEM medium containing antibiotics/FCS. The cells were then incubated at $37^{\circ} \mathrm{C}$ for $24-48 \mathrm{hrs}$.

\subsubsection{Techniques for production of targeted mutant mice (Joyner, 2000)}

The discovery that cloned DNA introduced into cultured mouse embryonic stem cells can undergo homologous recombination at specific loci has revolutionised our ability to study gene function in vitro and in vivo. In theory, this technique will allow us to generate any type of mutation in any cloned gene. Over twenty years ago, pluripotent mouse embryonic stem cells (ES) derived from inner cell mass (ICM) cells of mouse blastocysts were isolated and cultured (Martin, 1981; Evans and Kaufman, 1981). Using stringent culture conditions, these cells can maintain their pluripotent developmental potential even after many passages and following genetic manipulations. Genetic alterations introduced into ES cells in this way can be transmitted into the germline by producing chimera mice. Therefore, applying gene targeting technology to ES cells in culture gives the opportunity to alter and modify endogenous genes and study their functions in vivo.

\subsubsection{Production of targeted embryonic stem cell clones}

\subsection{Preparation of MEFs feeder layers}

A frozen vial of MEFs was quickly thawed at $37^{\circ} \mathrm{C}$ and transferred to $10 \mathrm{ml}$ EMFI medium. After centrifugation at $270 \mathrm{x} \mathrm{g}$ for $5 \mathrm{~min}$, the cell pellet was gently resuspended in $10 \mathrm{ml}$ MEFs medium and plated on a $50 \mathrm{~mm}$ culture flask. Cells were incubated at $37^{\circ} \mathrm{C}$ in $5 \% \mathrm{CO}_{2}$. When the cells formed a confluent monolayer after three days, they were trypsinised, transferred to five $150 \mathrm{~mm}$ dishes and grown until they formed confluent monolayer, or directly treated with mitomycin $\mathrm{C}$. To treat the MEFs with mitomycin $\mathrm{C}$, the medium was removed and $10 \mathrm{ml}$ fresh medium containing 100 $\mu \mathrm{l}$ mitomycin $\mathrm{C}(1 \mathrm{mg} / \mathrm{ml})$ was added. After 2-3 hrs of incubation, the monolayer of cells was washed twice with $10 \mathrm{ml}$ PBS. The cells were then resuspended with $10 \mathrm{ml}$ 
medium and gentle pipetting dissolved any cell aggregates. The cells were centrifuged, resuspended in MEFs medium and plated onto dishes, which were treated with $0.1 \%$ gelatine for $30 \mathrm{~min}$. The feeder cells were allowed to attach by incubation overnight at $37^{\circ} \mathrm{C}, 5 \% \mathrm{CO}_{2}$ or used after $2 \mathrm{hrs}$ of incubation. Before adding ES cells on the feeder layer, the medium was changed to ES cell medium.

\subsection{Growth of ES cells on feeder layer}

One vial of frozen ES cells was quickly thawed at $37^{\circ} \mathrm{C}$ and cells were transferred to a $12 \mathrm{ml}$ tube containing $6 \mathrm{ml}$ ES cell medium. After centrifugation, the cell pellet was resuspended in $5 \mathrm{ml}$ ES cell medium and plated on $6 \mathrm{~cm}$ dishes containing MEFs at $37^{\circ} \mathrm{C}, 5 \% \mathrm{CO}$. Next day the medium was changed. The second day, cells were washed with PBS, treated with $2 \mathrm{ml}$ trypsin/EDTA at $37^{\circ} \mathrm{C}, 5 \% \mathrm{CO}_{2}$ for $5 \mathrm{~min}$. The cells were gently pipetted up and down to dissolve cell clumps, resuspended with $5 \mathrm{ml}$ ES medium and centrifuged. The cell pellet was resuspended in $10 \mathrm{ml}$ ES cell medium and distributed either to 5 or 6 dishes $(6 \mathrm{~cm})$ or to 2 dishes $(10 \mathrm{~cm})$ containing feeder layers. The cells were passaged every second day as described above.

\subsection{Electroporation of ES cells}

ES cells, which have grown for two days in $10 \mathrm{~cm}$ dishes, were trypsinised. The cell pellet was resuspended in $20 \mathrm{ml}$ PBS and centrifuged. The cell pellet was then resuspended in $1 \mathrm{ml}$ PBS. The $0.8 \mathrm{ml}$ of cell suspension was mixed with $40 \mu \mathrm{g}$ of linearised DNA-construct and transferred into an electroporation cuvette. The electroporation was performed at $240 \mathrm{~V}, 500 \mu \mathrm{F}$ with the Bio-Rad gene pulser ${ }^{\mathrm{rM}}$ apparatus. After electroporation, the cuvette was placed on ice for $20 \mathrm{~min}$. The cell suspension was transferred from cuvette into $20 \mathrm{ml}$ of ES cell medium and plated onto two $10 \mathrm{~cm}$ dishes containing feeder layers. The medium was changed every next day. Two days after the electroporation, the drugs for selection were added (active G418 at $400 \mu \mathrm{g} / \mathrm{ml}$ and gancyclovir at $2 \mu \mathrm{M})$. The medium was changed every day. After about eight days of selection, drug resistant colonies have appeared and were ready for screening by Southern blot analysis. 


\subsubsection{Growing ES cells for Southern blot analysis}

The drug resistant colonies that were formed after about eight days of selection were picked with a drawn-out Pasteur pipette under a dissecting microscope. Each colony was transferred into a 24-well plate containing feeders and ES cell medium. After 2 days, the ES cells were trypsinised with $100 \mu$ trypsin for 5 min and resuspended in $500 \mu \mathrm{l}$ ES cell medium. Half of the cell suspension in each well was transferred to a well on two different 24-well plates, one gelatinised plate, and the other containing feeder cells (master plate). The gelatinised plate was used for preparing DNA and the master plate was kept frozen.

\subsubsection{Production of chimeras by injection of ES cells into blastocysts}

The standard procedure is to inject 10-20 ES cells from 129/Sv, which are recombinant for the targeted locus, into the blastocoel cavity of recently cavitated blastocysts that have been recovered by flushing the uteri of day 4 pregnant mice $(\mathrm{C} 57 \mathrm{BL} / 6 \mathrm{~J})$. After injection, embryos are cultured for a short period (2-3 hrs) to allow re-expansion of the blastocoel cavity and then transferred to the uterine horns of day three pseudopregnant mice. Pseudopregnant females are obtained by mating 6-8 weeks old oestrous females with vasectomised males.

\subsubsection{Detection of chimerism and mice breeding}

The most convenient and readily apparent genetic marker of chimerism is coat color. Chimeric males (and sometimes females) are bred to wildtype mice to ascertain contribution of the ES cells to germline. Once a germline chimera has been identified, the first priority will be to obtain and maintain the targeted allele in living animals. The chimeras were bred with C57BL/6J and with 129/Sv mice, respectively, to compare the phenotypes in two different genetic backgrounds. 


\subsubsection{Gene silencing by RNA interference}

The term RNA interference (RNAi) describes the use of double-stranded RNA to target specific mRNA for degradation, thereby silencing their expression. RNAi is one manifestation of a broad class of RNA silencing phenomena that are found in plants, animals and fungi (Cogoni and Macino, 2000). The discovery of RNAi has changed the understanding of how cells guard their genomes, led to the development of new strategies for blocking gene function and may yet yield RNA-based drugs to treat human diseases.

\subsubsection{Overview of the RNAi mechanism}

In the initiation step, input dsRNA is digested into 21-23 nucleotide small interfering RNAs (siRNAs), which have also been named "guide RNAs" (Elbashir et al., 2001). The siRNAs are produced when the enzyme Dicer, a member of the RNase III family of dsRNA-specific ribonucleases, processively cleaves dsRNA (introduced directly or via a transgene or virus) in an ATP-dependent. The dsRNA successive cleavage events degrade the RNA to 19-21 bp duplexes (siRNAs), each with 2-nucleotide 3' overhangs (Hutvagner et al., 2002). In the effector step, the siRNA duplexes bind to a nuclease complex to form what is known as the RNA induced silencing complex, or RISC. An ATP-depending unwinding of the siRNA duplex is required for activation of the RISC. The active RISC then targets the homologous transcript by base pairing interactions and cleaves the mRNA 12 nucleotides from the 3' terminus of the siRNA (Elbashir et al., 2001). Consensus RNase III active site in the second RNase III domain inactivates the central catalytic sites, resulting in cleavage at 22-nucleotide intervals. 


\subsubsection{Preparation of adaptor oligos}

The 21 bp single stranded sense and anti-sense oligonucleotides containing ClaI, NotI and XhoI restriciton enzymes (CNX-sense: 5'-CCCCCCATCGATGCGGCCGCC-3'; CNX-anti sense: 5'-AAAACCCTCGAGGCGGCCGCA-3') were diluted to a final concentration of $100 \mathrm{pmol} / \mu \mathrm{l}$. Then for each of the above oligonucleotides $2.5 \mu \mathrm{l}$ was added to $45 \mu \mathrm{l}$ of annealing buffer (100 $\mathrm{mM} \mathrm{NaCl}$ and $50 \mathrm{mM}$ HEPES). After denaturation for $4 \mathrm{~min}$ at $95^{\circ} \mathrm{C}$, the oligonucleotides were incubated for $10 \mathrm{~min}$ at $85^{\circ} \mathrm{C}$, $80^{\circ} \mathrm{C}$ and $75^{\circ} \mathrm{C}$, then for $4 \mathrm{~min}$ at $70^{\circ} \mathrm{C}, 65^{\circ} \mathrm{C}, 60^{\circ} \mathrm{C}, 55^{\circ} \mathrm{C}$ and $53^{\circ} \mathrm{C}$ respectively, followed by for $10-15 \mathrm{~min}$ at $37^{\circ} \mathrm{C}$, and then cooled down on ice.

\subsubsection{Generation of transgenic mice}

Generation of transgenic mice was performed by "Transgenic Service" of Max Planck Institute for Experimental Medicine in Göttingen by pronuclear microinjection of DNA. Method for transgenic animal production was based on Hogan et al. (1986).

\subsubsection{Preparation of DNA for pronuclear microinjection}

Transgenic constructs were released from cloning vector by restriction digestion. Digested fragments were separated by agarose gel electrophoresis (without EtBr) in the way that $25 \mu \mathrm{g}$ of digested plasmid was loaded to many slots of the gel. After separation, outer lanes were cut out and stained with EtBr. After staining, gel was reconstructed and appropriate gel slices were cut out from the rest of the gel under UV light. DNA was then eluted from gel with QIAquick extraction kit and filtered through $0.45 \mu \mathrm{m}$ microfilter (Milipore). Concentration of DNA was estimated by $\mathrm{EtBr}$ electrophoresis of DNA aliquots in comparison with Smart ladder marker (defined DNA amounts in each band). For microinjection, DNA was diluted to $4 \mathrm{ng} / \mu \mathrm{l}$ in microinjection buffer (10 mM Tris, $\mathrm{pH}$ 7.5; 0.1 mM EDTA, $\mathrm{pH} 8.0$ ). 


\subsection{Computer analysis}

For the analysis of the nucleotide sequences, programs like BLAST, BLAST2, MEGABLAST and other programs from National Center for Biotechnology Information (NCBI) were used (www.ncbi.nlm.nih.gov). Information about mouse alleles, phenotypes and strains were used from Jackson Laboratory (www.informatics.jax.org). For protein studies ExPASy tools (www.expasy.ch) were used. Mouse genome sequence and other analysis on mouse genes, transcripts and putative proteins were downloaded from Celera discovery system (www.celera.com). 


\section{RESULTS}

\subsection{Generation of polyclonal antibody against Pelota and expression analysis}

\subsubsection{Generation and purification of polyclonal anti-Pelo antibody}

To study the expression of Pelo protein and determine the subcellular localisation of Pelo, anti-Pelo specific antibody was generated against Pelo-GST fusion protein. PeloGST fusion protein was purified as described in methods section (2.2.15.3) and used for the immunisation of rabbits. To remove other proteins from polyclonal serum, $\operatorname{IgG}$ purified antibody was isolated as described in methods section (2.2.15.6) and checked for specificity by Western blot analysis. Total protein extracts from mouse ES-, mouse NIH 3T3- and human LNCaP cells were separated on SDS-PAGE gel and transferred onto nitrocellulose membrane. As shown in Figure 3.1A, the IgG polyclonal antibody did not recognise a specific protein in any protein extracts. In order to purify anti-Pelo antibody from serum, Pelo-GST fusion protein was coupled to NHS-Hi Trap column and used for the purification of anti-Pelo antibody (2.2.15.5). The purified Pelo-GST antibody was checked by Western blot (Fig 3.1B) and immunostaining analysis (Fig 3.4D). The affinity purified antibody detects approximately $44 \mathrm{kDa}$ protein in all extracts and further high molecular weight proteins. Because the polyclonal antibody was raised against Pelo-GST fusion protein and purified with same protein, the affinity purified antibody should contain anti-Pelo and anti-GST antibodies. The specificity of anti-Pelo polyclonal antibody to recognise the $44 \mathrm{kDa}$ protein was determined by competition assay.

Western blot with protein extracted from testes was incubated with anti-Pelo antibody (Fig 3.2A) and the other blot was probed with anti-Pelo antibody which was preincubated with GST protein to remove other unspecific antibodies (Fig 3.2B). In the competition assay only a specific band of $44 \mathrm{kDa}$ was recognised. These results demonstrate that purified anti-Pelo antibody specifically detects the $44 \mathrm{kDa}$ Pelo protein. 
A

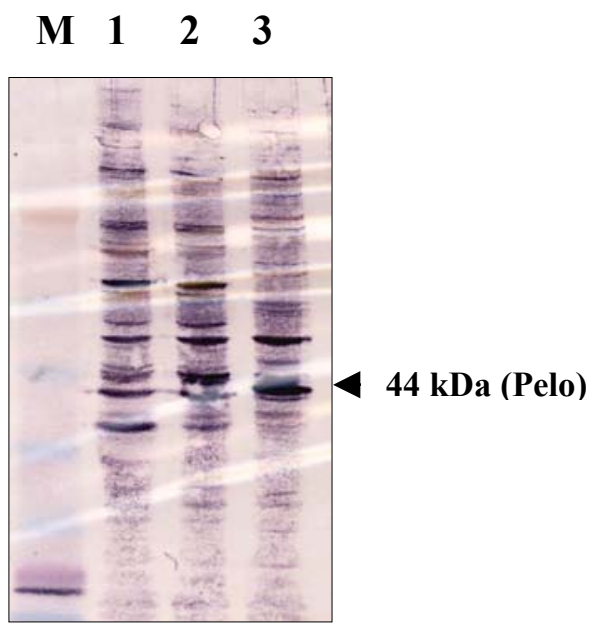

B

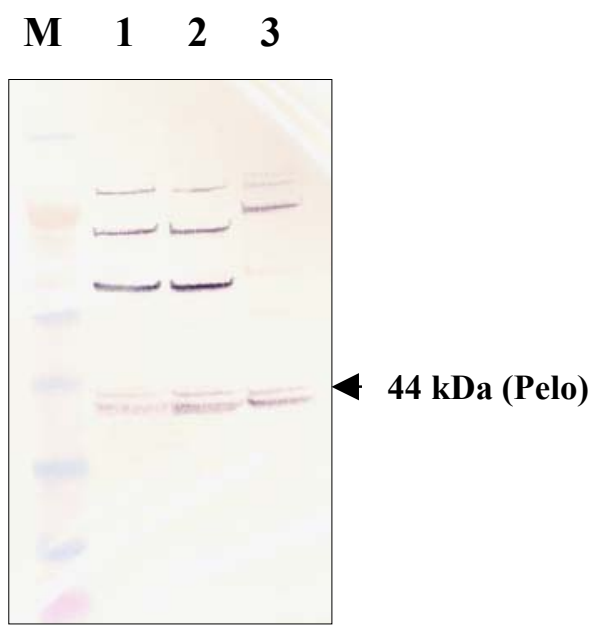

Figure 3.1: Western blot analysis using polyclonal anti-Pelo antibody

Western blot with total protein extracts from ES- (1), NIH 3T3- (2) and LNCaP (3) cells was probed with IgG anti-Pelo antibody (A) and GST-Pelo purified anti-Pelo antibody (B).

$\mathbf{A}$

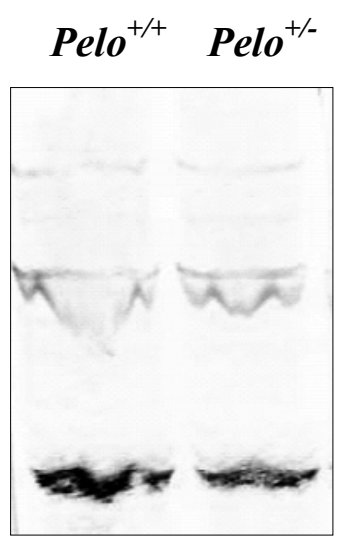

B

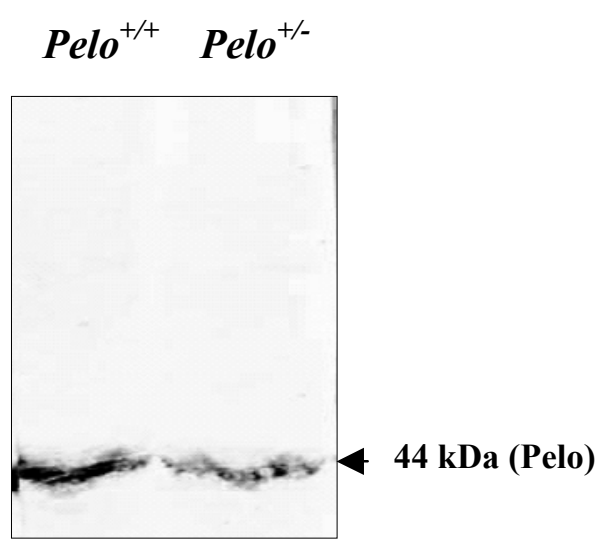

Figure 3.2: Competition assay to verify the specificity of polyclonal anti-Pelo antibody

Western blots with testes protein extracts from $\mathrm{Pelo}^{+/+}$and $\mathrm{Pelo}^{+/}$animals were probed with Pelo-GST purified anti-Pelo antibody (A) and with GST-preincubated anti-Pelo antibody (B). Dilutions of antibodies were 1:100. 


\subsubsection{Cellular localisation of Pelo protein in mouse embryonic fibroblasts}

Affinity purified polyclonal anti-Pelo antibody was used to identify the subcellular localisation of Pelo protein. In parallel, GFP-fluorescence was determined in GFP-Pelo transgenic fibroblasts which were isolated and cultured from GFP-Pelo transgenic embryos. As shown Figure 3.3, GFP-fluorescence is restricted to the cytoskeleton and cytoplasm. GFP-Pelo transgenic fibroblasts were then probed with anti-GFP (Fig 3.4A) and anti-Pelo (Fig 3.4D) antibodies. After incubation of fibroblasts with secondary antibodies, slides were then probed with FITC-labeled phalloidin which is specifically associated with the stress actin filaments (Fig 3.4B; E). As shown in Figure 3.4A and 3.4D, anti-Pelo and anti-GFP antibodies recognise a similar subcellular structure in GFP-Pelo transgenic fibroblasts. Colocalisation of actin filaments with the phalloidin staining demonstrates that the Pelo protein is associated to cytoskeleton.

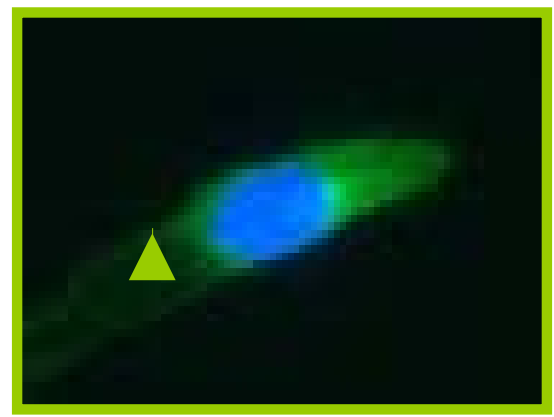

Figure 3.3: Pelo protein is localised at cytoskeleton

GFP-fluorescence was detected at cytoskeleton (arrow) of fibroblasts which were isolated and cultured from GFP-Pelo transgenic embryos. 

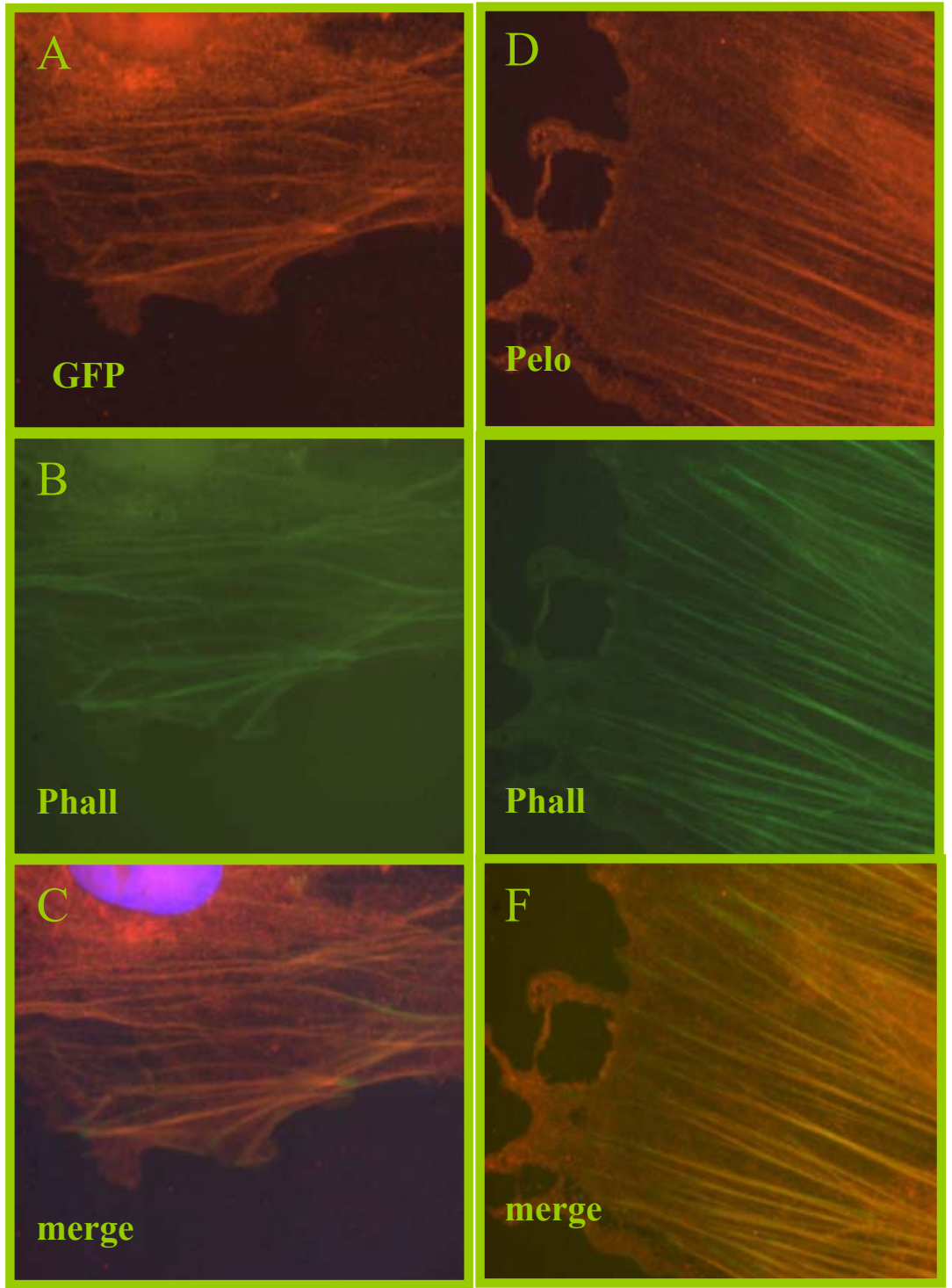

Figure 3.4: Association of Pelo protein to cytoskeleton of GFP-Pelo transgenic fibroblasts

GFP-Pelo transgenic fibroblasts were fixed in 4\% paraformaldehyde and probed with anti-GFP (A) and anti-Pelo (D) antibodies. The slides were incubated with Cy3-labelled goat anti-rabbit IgG as a secondary antibody. Fibroblasts in A and D were then incubated with FITC-labelled phalloidin. Colocalisation of the Pelo and GFP stained actin filaments in red (A, D) and phalloidin stained actin filaments in green $(B, E)$ appears orange in the merged image $(\mathrm{C}, \mathrm{F})$. 


\subsubsection{Expression of Pelo protein in different cell lines}

To validate the expression of Pelo protein in vitro, Western blot analysis with total protein extracted from mouse and human cell lines was performed with the polyclonal anti-Pelo antibody. As shown in Figure 3.5, Pelo protein is present in all studied cell lines.

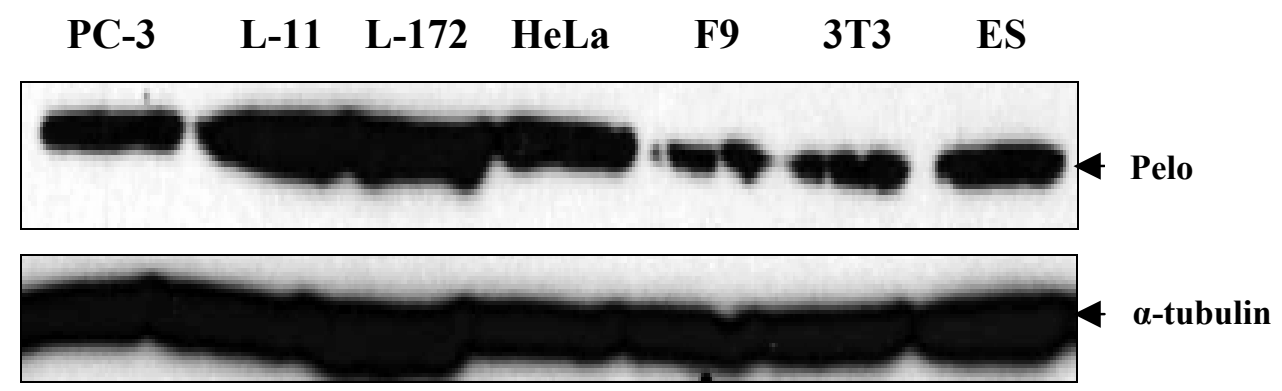

Figure 3.5: Expression of Pelo protein in different cell lines

The 44 kDa Pelo protein was detected in all studied cell lines: PC-3, human prostate carcinoma cell; L11, LNCaP-11 human prostate carcinoma cell androgen dependent; L-172, LNCaP-172 human prostate carcinoma cell androgen independent; HeLa, human cervical cancer cell; F9, murine teratocarcinoma cell; 3T3, NIH 3T3 mouse embryonic fibroblasts; ES, mouse embryonic stem cell. $50 \mathrm{kDa} \alpha$-tubulin protein served as a loading control. 


\subsubsection{Expression of Pelo protein in mouse tissues}

To determine the expression pattern of the Pelo protein in different tissues, Western blot analysis was performed. Total protein was extracted from different tissues of adult mice, including testis, lung, heart, spleen, thymus, stomach, kidney and liver, electrophoresed on SDS-PAGE and transferred onto a nitrocellulose membrane. The polyclonal anti-Pelo antibody recognised the $44 \mathrm{kDa}$ Pelo protein in all studied tissues (Fig 3.6).

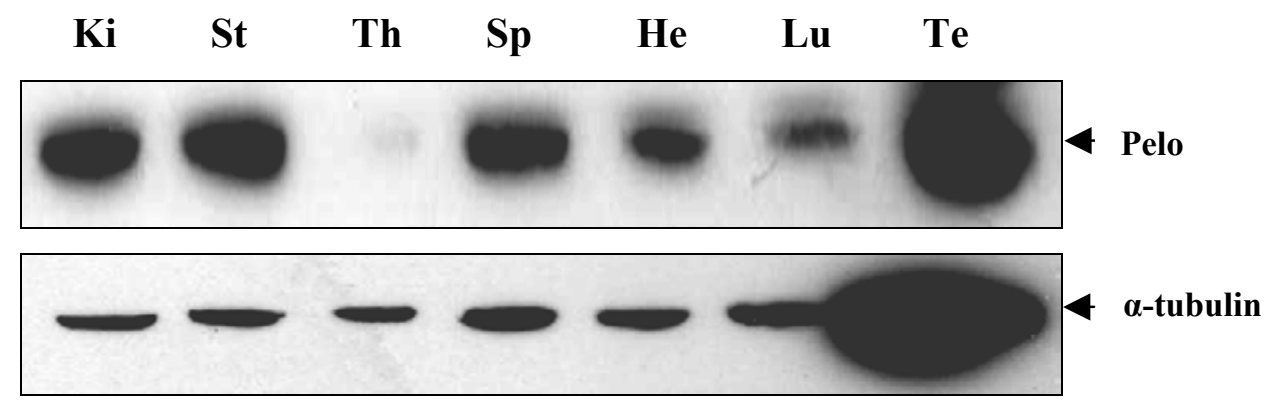

Figure 3.6: Expression of Pelo protein in different tissues of mouse

A polyclonal antibody raised against Pelo-GST fusion protein was used to probe Western blot with protein extracted from different tissues. The $44 \mathrm{kDa}$ band was detected in all studied tissues. Ki, kidney; St, stomach; Th, thymus; Sp, spleen; He, heart; Lu, lung; Te, testis. The membrane was stripped and subsequently probed with a monoclonal anti $\alpha$-tubulin antibody to monitor the loading.

\subsubsection{Expression of Pelo protein during testicular development and in testes of different mutant mice}

To evaluate the expression of the Pelo gene during postnatal development of testis at the protein level, total protein extracts from testes of mice at different developmental stages were analysed by Western blot. The $44 \mathrm{kDa}$ Pelo protein was found in lysates of all testicular stages studied (Fig 3.7A). 
The presence of the Pelo protein was also examined in the testes of mutant mice, in which spermatogenesis is arrested at different stages: $\mathrm{W} / \mathrm{W}^{\mathrm{V}}, \mathrm{Insl}^{-/-}$, olt/olt and qk/qk. $\mathrm{W} / \mathrm{W}^{\mathrm{V}}$ mice are characterised by lack of all germ cells (de Rooij and Boer, 2003), in Insl3 ${ }^{-/-}$mutants spermatogenesis is arrested at pachytene spermatocyte stage (Zimmermann et al., 1999). In olt/olt, spermatogenesis is arrested at round spermatid stage and in qk/qk at elongated spermatid stage (Bennett et al., 1971, Moutier, 1976). The $44 \mathrm{kDa}$ Pelo protein was detectable in testes of all these mutants (Fig 3.7B). Detection of $44 \mathrm{kDa}$ Pelo protein in $\mathrm{W} / \mathrm{W}^{\mathrm{V}}$ mutants demonstrates that Pelo is expressed in somatic testicular cells.

A

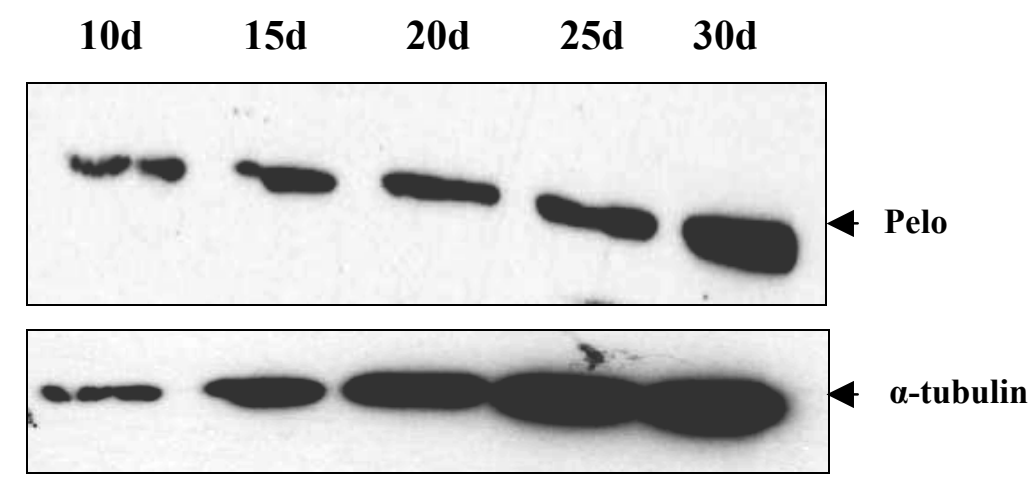

B

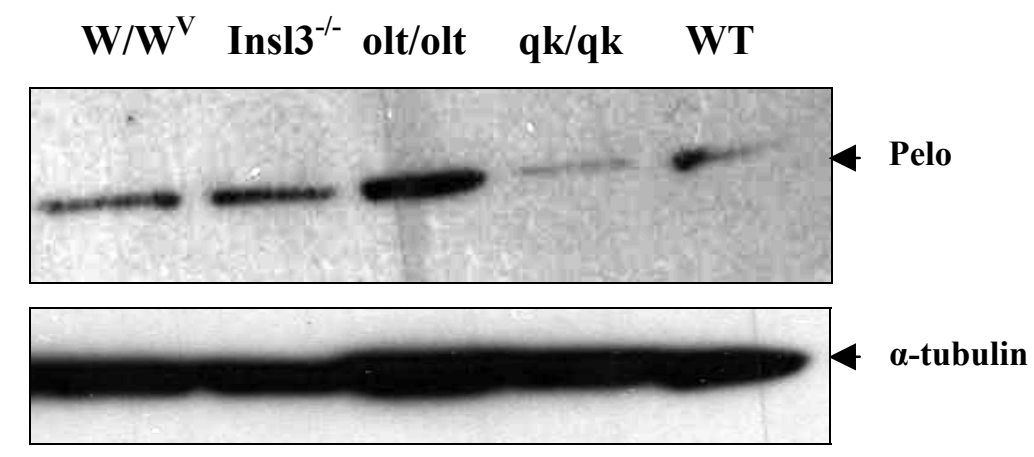

Figure 3.7: Expression of Pelo protein during testicular development and in testes of different mutant mice

Polyclonal anti-Pelo antibody recognises the $44 \mathrm{kDa}$ protein in testicular lysates from all postnatal developmental stages (A) and mutant mice. $50 \mathrm{kDa} \alpha$-tubulin protein is shown as a control for protein loading. 


\subsubsection{Expression of Pelo during preimplantation stages}

To determine the profile of preimplantation expression of Pelo gene, RT-PCR was performed with total RNA prepared from 1-, 2-, 4-cell, morula and blastocyst stages. To control the relative abundance of Pelota transcript, we included RT-PCR analysis for the Gapdh gene which is ubiquitously expressed throughout preimplantation. The expression level of Pelo was high in unfertilized eggs, then decreased in 2- and 4-cell stages and increased again after 8-cell stage (Fig 3.8). These results suggest that maternal Pelo transcript is decreased from 1- to 4-cell stages whereas the expression of embryonic Pelo transcript starts at 8-cell stage.

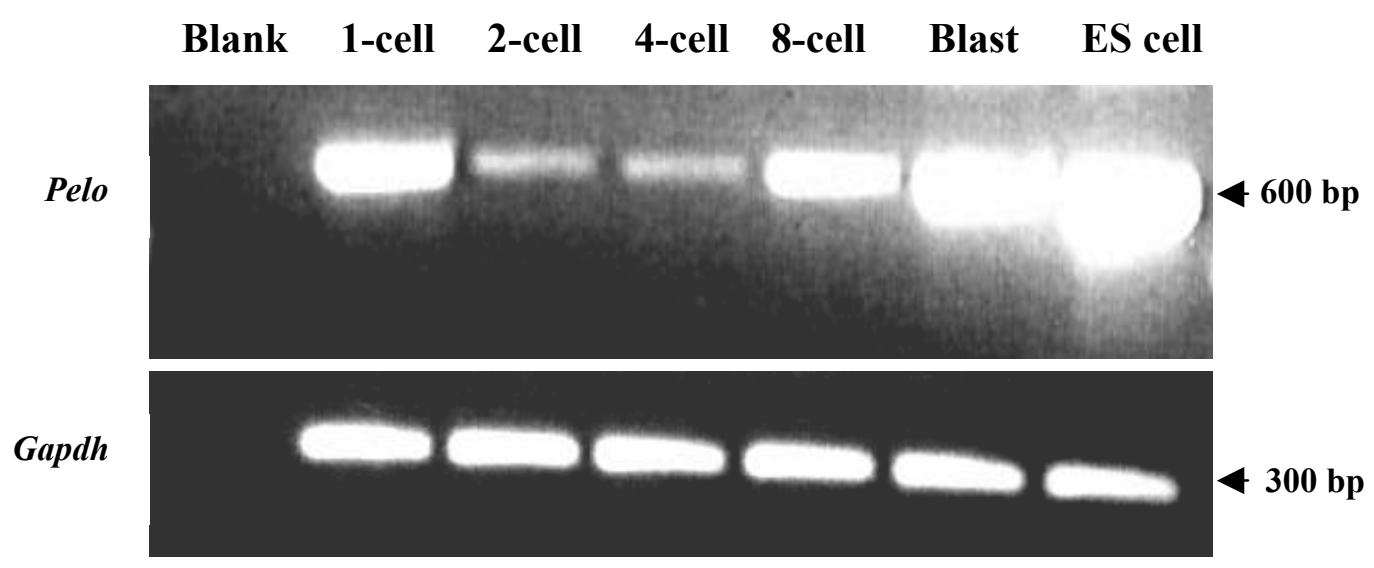

Figure 3.8: RT-PCR expression analysis of Pelo gene during preimplantation stages

RT-PCR was performed to detect Pelo and Gapdh transcripts in total RNA preparation from 1-, 2-, 4-cell, morula, blastocysts stages and ES cells.

\subsubsection{Expression and localisation of Pelo protein in testicular cell fractions}

In order to confirm the results of immunocytochemistry analyses, we performed Western blot analyses with protein extracted from different cellular fractions of testis, namely cytoplasmic, nuclear, cytoskeleton and membrane protein fractions. The blot was subsequently probed with different antibodies. The polyclonal anti-Pelo antibody 
was found to recognise a $44 \mathrm{kDa}$ protein in cytoskeleton and membrane fractions. The restricted localisation of $\alpha$-actinin and $\mathrm{H} 3$ histone in cytoskeleton and nuclear fractions, respectively, suggests the proper separation of different fractions. These results confirm the subcellular localisation of Pelo is at cytoskeleton. The presence of Pelo in the membrane fraction, as shown in Western blot, might be due to association of cytoskeleton to the membrane. The results clearly demonstrate that expression and subcellular localisation of Pelo protein is at cytoskeleton as well as in the membrane (Fig 3.9).

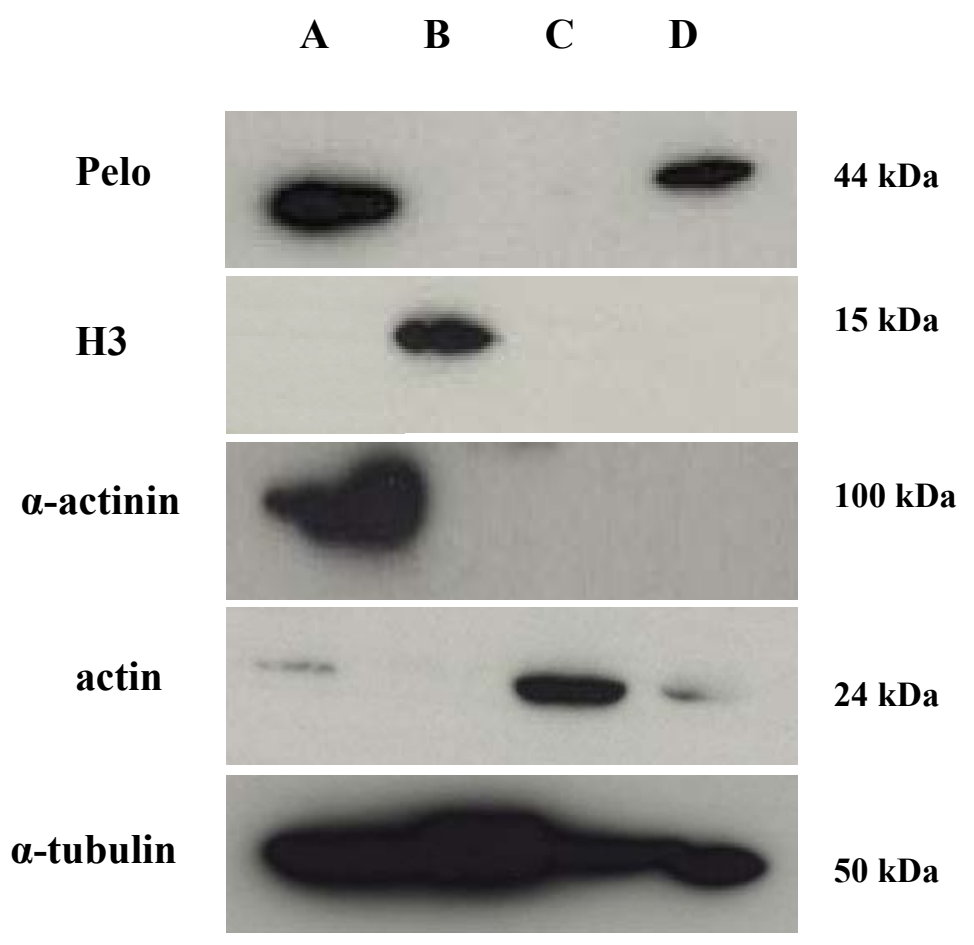

Figure 3.9: Expression and localisation of Pelo and other protein in testicular cell fractions

Western blot analysis with protein extracted from different cellular fractions of adult mouse testis. A, cytoskeleton; B, nuclear; C, cytoplasmic and D, membrane fraction. The blot was subsequently probed with antibodies against Pelo, H3 histone, $\alpha$-actinin, actin and $\alpha$-tubulin. The restricted localisation of H3 histone and $\alpha$-actinin to nuclear and cytoskeleton fractions, respectively, suggests the proper separation of different fractions. 


\subsection{Knockdown of Pelota gene using inducible siRNAs system in vitro}

\subsubsection{Overview of inducible siRNAs system}

RNA interference (RNAi) is a process of sequence-specific posttranscriptional gene silencing mediated by double-stranded RNA and is a powerful genetic approach to analyse gene function in many organisms. The endogenous mediators of sequencespecific mRNA degradation are 21- and 22-nt short interfering RNAs (siRNAs) generated from longer double-stranded RNAs by the ribonuclease III activity of the evolutionary conserved dicer enzyme. The functional siRNA silencing mechanism by dsRNA was first shown in C. elegans (Fire et al., 1998). Recently, it was demonstrated that RNAi-mediated gene silencing can be reached in cultured mammalian cells by delivery of chemically synthesised short ( $<30 \mathrm{nt})$ double-stranded siRNA molecules or by endogenous expression of short hairpin RNAs (shRNAs) bearing a fold-back stemloop structure.

Plasmid- and viral vector-based constitutive expression of shRNAs by RNA polymerase III U6 and H1 small nuclear RNA promoters (U6 or H1) often result in stable and efficient suppression of target genes. However, the inability to adjust levels of suppression has imposed limitations in the analysis of genes essential for cell survival, cell cycle regulation, and cell development. Besides, gross suppression of a gene for longer periods may result in nonphysiological responses. This problem can be circumvented by generating inducible regulation of RNAi in mammalian cells. The two most widely used inducible mammalian systems use tetracycline- or ecdysoneresponsive transcriptional elements.

Using a tet on/off strategy it has been shown that the exogenous control of shRNAs expression in tissue culture is possible (van de Wetering et al., 2003). The Tet on/off strategy relies on two components: a Tet-repressor (TetR) and a Tet-responsive promoter, the activity of which is regulated by binding or release of the TetR. In the absence of the tetracycline repressor (TetR), the tet $O$ sites in the tetracycline responsive promoter are bound by the TetR and transcription of the shRNA is repressed (Fig 3.10). 
Conversely, in the presence of Dox, TetR is released from the tet $O$ sites, allowing transcription of shRNA and thus, the mRNA-specific knockdown to proceed.

The essential role of Pelota for cell viability prevented us to establish a cell line from Pelo deficient embryos. Therefore, the tetracycline inducible siRNA system was suggested to be a convenient strategy to establish a stable cell line and conditional induction of Pelo-shRNA. The conditional induction of Pelo-shRNA should allow for time-controlled loss-of-function and thus circumventing the lethal phenotype.

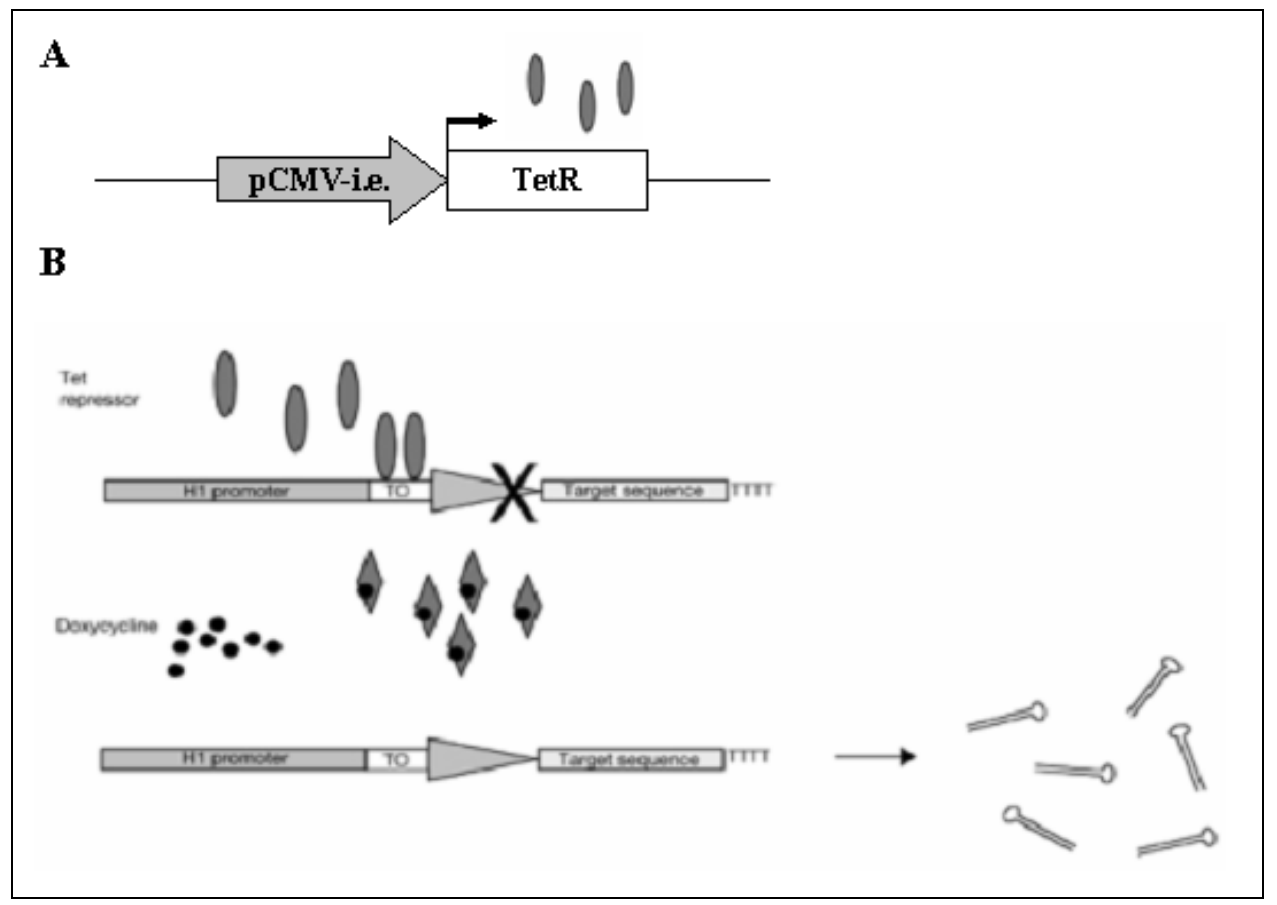

Figure 3.10: Overview of the tetracycline inducible siRNA system

(A) Schematic representation of the vector containing the TetR gene, which is controlled by CMV promoter that is highly transactivated in different tissues. (B) Schematic representation of the proposed pTER 'roadblock'. Transcription of the H1 promoter is blocked in cells expressing the Tet repressor (upper panel). Addition of doxycycline to the medium inhibits the binding of the Tet repressor and transcription is derepressed (lower panel). 


\subsubsection{Selection of siRNA sequences for specific targeting of Pelo mRNA}

To facilitate the knockdown of the murine Pelo transcripts by the RNAi system, three different RNAi target sequences and their complementary oligonucleotides were designed (Fig 3.11A, B). The RNAi forward oligonucleotide was annealed with its complementary oligonucleotide and then cloned into the pTER vector, which was linearised with BglII and HindIII restriction enzymes (Fig 3.11C).

The Pelo gene has 3 exons which code for a 1624 bp mRNA. First 19 bp targeted sequences are located at 1009-1025 nucleotides (nt), whereas a second sequence is located at 1045-1064 nt and a third targeted sequence is located at 627-646 nt of the murine Pelo mRNA sequence. To ensure unique targeting of the murine Pelo mRNA, BLAST search (www.ncbi.nlm.gov/BLAST) was performed to prevent unspecific knockdown of unrelated mRNA sequences. 


\section{A. RNAi forward oligonucleotide:}

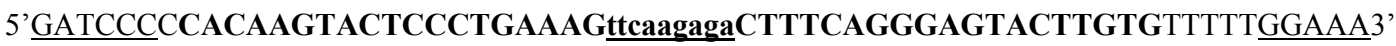

\section{B. RNAi reverse oligonucleotide:}

5'AGCTTTTCCAAAAACACAAGTACTCCCTGAAAGtctcttgaaCTTTCAGGGAGTACTTGTGGGG 3'

C. Annealing of oligonucleotides to generate a siRNA template:

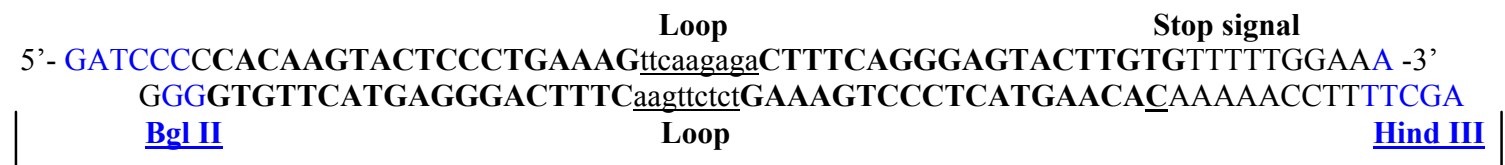

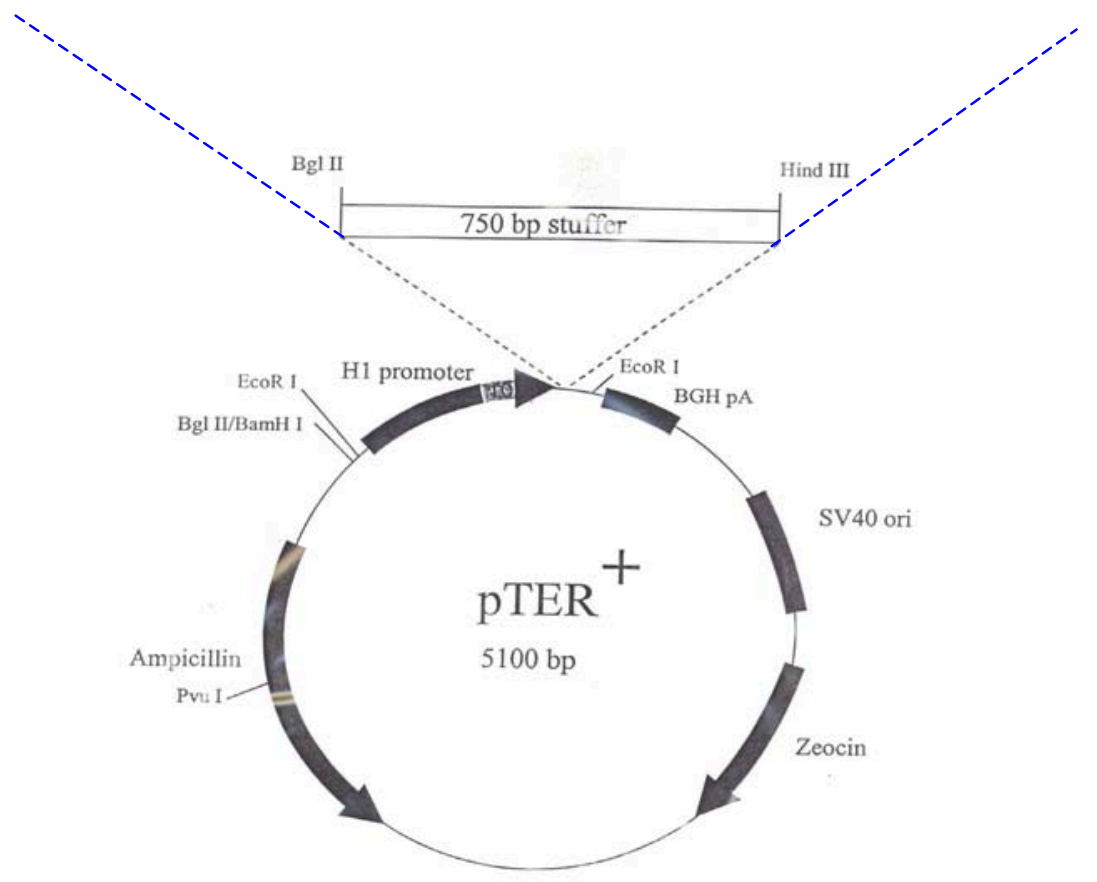

Figure 3.11: Design of the Pelo-siRNA vector

A. RNAi forward oligonucleotide: The left BglII cloning overhang (capitals, underlined) is follwed a 19 bp Pelota specific knockdown sense sequence (bold), a 9 bp loop (lower case, underlined), the anti-sense Pelo-specific knockdown sequence (bold), followed by the TTTTT stop signal and the HindIII specific overhang (capitals, underlined). 
B. The RNAi reverse primer oligonucleotide contains the reverse complementary sequence for the forward oligonucleotide therefore producing an siRNA sequence which is then transcribed into a short hairpin loop (shRNA) by transcription with the PolIII enzyme. The cloning of annealed oligonucleotides (C) into pTER expression vector results in the Pelo-siRNA knockdown vector.

The pTER backbone is shown in black and the RNAi-oligonucleotide cloning region is indicated in blue. H1 TO promoter, histone 1 promoter containing a tetracycline operator sequence; CMV-i.e., human cytomegalovirus immediate early promoter; BGH pA, bovine growth hormone polyadenylation signal.

To confirm the successful integration of three different siRNA templates into pTER vector, a test digestion was performed with EcoRI restriction enzyme. The vector contains two EcoRI sites which are flanking the promoter region and the cloning site (Fig 3.11). DNA from positive clones was extracted as described in methods section (2.2.1.1.1) and an integration of the insert was confirmed by sequencing. The result of the sequencing analysis demonstrated that all three Pelo-siRNA vectors did harbour the selected Pelo-siRNA templates. The three different Pelo-siRNA vectors (Pelo1-siRNA, Pelo2-siRNA and Pelo3-siRNA) were further analysed for knockdown efficiency in cell culture.

The R1 ES cells were used to determine the efficiency of Pelo-siRNA vectors to knockdown of Pelo transcript. The ES cells were transfected with Bst1107 digested pcDNA6/TR vector, which contains tetracycline repressor under the control of CMV promoter (Fig 3.12). Transfected cells were cultured in standard ES cell medium containing Blasticidin. After 10 days, Blasticidin resistant-clones were genotyped for the integration.

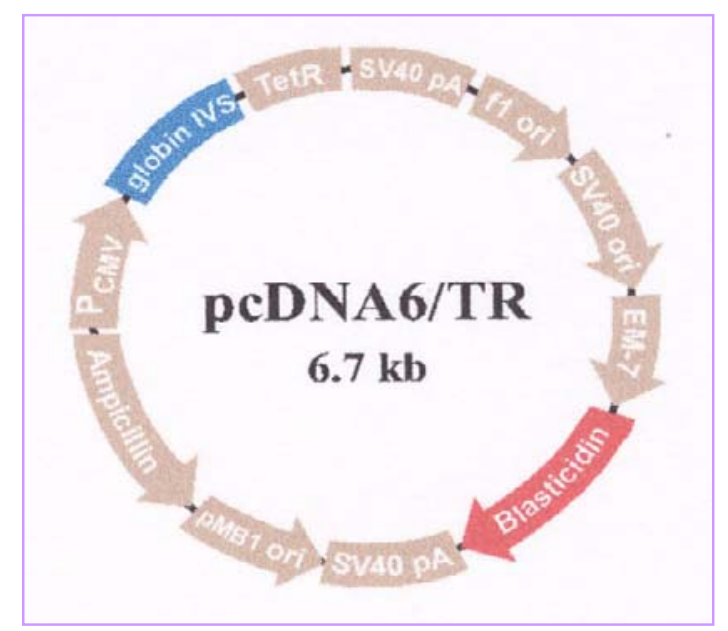


Figure 3.12: Schematic representation of the pcDNA6/TR vector

pcDNA6/TR is a $6662 \mathrm{bp}$ vector that sustains high level of the TetR gene expression under the control of human CMV promoter. The T-REx coding region shown in blue and brown (IVS, T-REx intron and TREx cDNA) is followed by a SV40 pA. Blasticidin resistance gene is shown in red for mammalian cell selection.

The pcDNA6/TR vector was detected in the genome of ES cells by PCR assay using primers Blast-F and Blast-R, which contain sequences of Blasticidin gene (Fig 3.13A). One Blasticidin-resistant ES clone was then separately transfected with Pelo1-siRNA, Pelo2-siRNA and Pelo3-siRNA vectors. Transfected cells were cultured in ES cell medium with $200 \mathrm{ng} / \mathrm{ml}$ of Zeocin. After 10 days culture, four Zeocin-resistant clones were selected from each transfection experiment and genotyped for insertion of PelosiRNA vectors in the genome by PCR analysis (Fig 3.13B). The used primers Zeo-F and Zeo-R contain sequences located in Zeocin gene.

\section{A. PCR with Blasticidin primers}

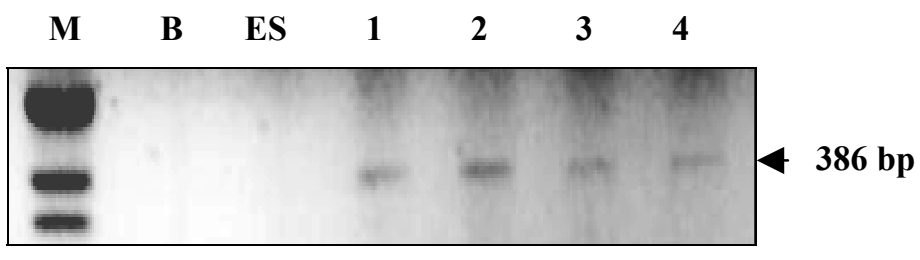

\section{B. PCR with Zeocin primers}

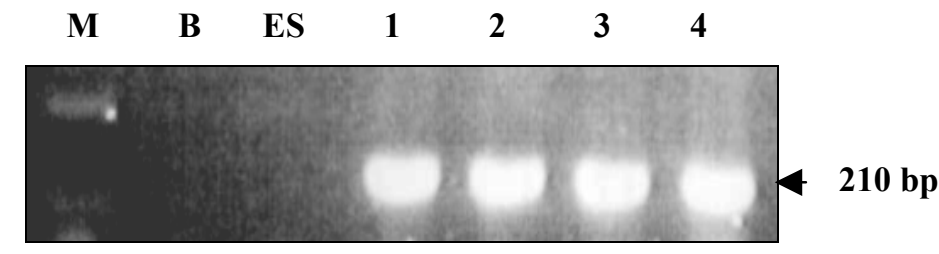

Figure 3.13: PCR screening of Pelo-siRNA positive clones

Four different Pelo-siRNA specific clones (1-4) were generated using the pTER vector. To identify successfully transfected plasmids, PCR approach was established as described in methods section (2.2.8). Resulting products were run on a $2 \%$ agarose gel from individual bacterial colonies with individual clone numbers indicated above the lanes. B, blank control, no DNA template; ES, negative control (untransfected); (A) $386 \mathrm{bp}$, PCR fragment of transfected pcDNA6/TR vector. (B) $210 \mathrm{bp}$, the ligated oligonucleotides in the pTER vector indicating the positive clones. 


\subsubsection{Efficiency of Pelo-siRNAs to knockdown the Pelo transcript}

To determine the knockdown efficiency of the three different individual RNAi constructs (Pelo1-3-siRNA), three selected clones from each transfection assay were cultured for 3 days with Doxycycline (Dox) at a concentration of $2 \mu \mathrm{g} / \mathrm{ml}$. Total RNA and protein were extracted from Dox-treated ES cells. The Northern blot analysis with total RNA isolated from Dox-treated ES cell clones which are transfected with Pelo1siRNA constructs revealed that there is no significant reduction of the Pelo mRNA. Rehybridisation of the blot with $\beta$-actin probe shows that the observed reduction in intensity of Pelo band in clone 1 and 2 compared to control is due to unequal amount of RNA loading (Fig 3.14).

Expression of Pelo in Dox-treated clones was further confirmed by Western blot at the protein level. As shown in Figure 3.15, no apparent reduction in the level of Pelo protein of Pelo1-siRNA transfected clones was found. Similar results were also obtained by analyses of Pelo2-siRNA and Pelo3-siRNA transfected vectors. These results suggest that the Pelo-shRNAs are not able to knockdown the Pelo mRNA. 


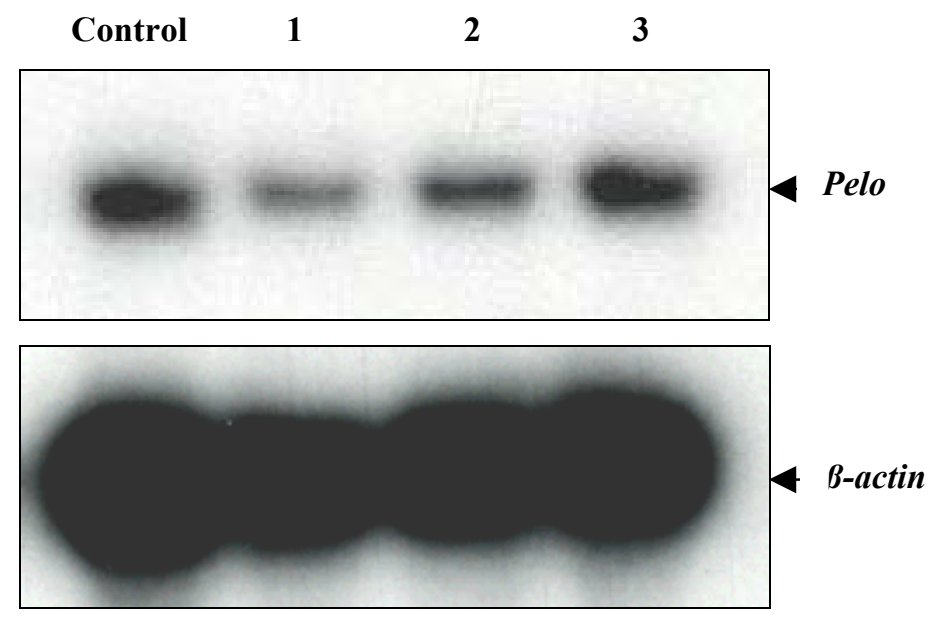

Figure 3.14: Northern blot analysis showing Pelo expression in different Pelo1-siRNAi recombinant clones

Total RNA $(20 \mu \mathrm{g})$ was extracted from Pelo1-siRNA recombinant clones (1-3) and subjected to Northern blot hybridisation using murine Pelota cDNA as a probe. Control lane contains RNA isolating from untransfected ES cells. The probe hybridised with $1.6 \mathrm{~kb}$ murine Pelota cDNA. Equal loading of the RNA samples were confirmed by rehybridisation of blot with $1.7 \mathrm{~kb} \beta$-actin probe.

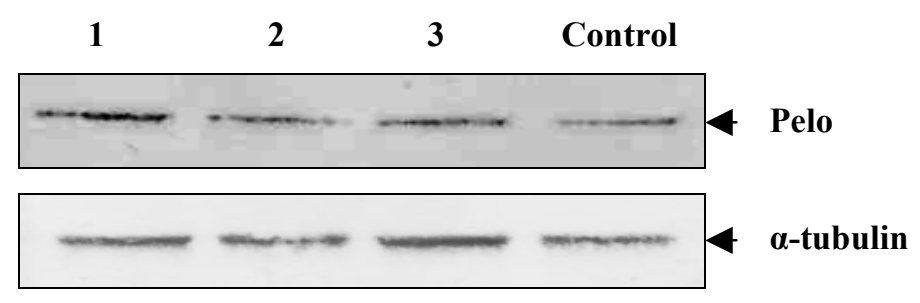

Figure 3.15: Western blot analysis of Pelo-siRNA knockdown efficiency

Protein was extracted from Pelo1-siRNA recombinant clones (1-3) and subjected to Western blot analysis using anti-Pelo antibody. Control lane contains protein isolating from untransfected ES cells. A monoclonal antibody against $\alpha$-tubulin was used as a loading control. 


\subsection{Pelota conditional knockout mice}

\subsubsection{Generation of conditional knockout targeting construct}

In order to conditionally disrupt the Pelota gene in the mouse, Pelota conditional allele was designed in pKSLoxPNT vector. In the floxed Pelo construct, two loxP sites were integrated in intron 1 and 3 ' flanking region of the gene. The neomycin phosphotransferase $(\mathrm{Neo})$ gene under the control of the phosphoglycerate kinase promoter was inserted upstream of the second $\operatorname{lox} P$ site. Introduction of the Herpes simplex virus thymidine kinase $(T K)$ gene at the $3^{\prime}$ end of the construct enabled us to use negative selection (Fig 3.18).

DNA of clone 16-kb, which contains the entire Pelo gene (Fig 3.16A) was digested with the restriction enzyme SpeI. The $9 \mathrm{~kb}$ and $6 \mathrm{~kb}$ SpeI fragments were purified from agarose gel. The 9-kb SpeI fragment was self-ligated to give the clone 9-kb SpeI (Fig 3.16B). The 6-kb SpeI genomic fragment was subcloned into the SpeI digested pBlueScript vector to produce the clone 6-kb SpeI (Fig 3.16C). The clones were generated by Dr. M. Sallam (Sallam, 2001) and used to construct the floxed Pelo targeting vector.

pKSLoxPNT vector (Fig 3.17A) was digested with HindIII and both $2 \mathrm{~kb}$ and $5 \mathrm{~kb}$ fragments were purified from agarose gel. The 2-kb HindIII fragment containing Neo/loxP fragment was cloned into HindIII digested clone 4H/S (Fig 3.16D) to obtain clone $\mathrm{Neo}-4 \mathrm{H} / \mathrm{S}$ (Fig 3.17C).

The 5-kb HindIII TK/loxP fragment of the vector was self-ligated to give the clone 2 . The $2 \mathrm{~kb}$ HindIII fragment containing exons 2 and 3 of Pelota gene was isolated from clone 6-kb SpeI and cloned into HindIII digested clone 2 to produce clone 3 (Fig 3.17D). 
$150 \mathrm{bp}$ fragment containing a sequence of intron 1 was amplified with forward primer containing SpeI site and reverse primer containing KpnI site. The 150-bp PCR fragment was subcloned into pGEMTeasy vector, then SpeI fragment was isolated and subcloned into clone 9-kb to obtain clone 4 (Fig 3.17B). The 2-kb KpnI fragment was isolated from clone 3 and subcloned into KpnI digested clone 4 to give clone 9 (Fig 3.17E).

To be able to introduce the Neo cassette in clone 9, oligonucleotide adaptor (pink line in Fig 3.17E) containing the sequence of ClaI-NotI-XhoI restriction sites was generated, annealed and ligated with ClaI/XhoI digested clone 9 to yield clone 10 (Fig 3.17F). The 6-kb HindIII/SpeI fragment was isolated from clone Neo-4H/S and ligated with HindIII/SpeI digested clone 10 to produce clone 11 (Fig 3.17G).

Finally, the NotI/XhoI fragment containing the $T K$ cassette was inserted in NotI/XhoI digested clone 11 to complete the final targeting vector, clone 12, loxP-Pelo-Neo-loxPTK (Fig 3.17I). The DNA of the final targeting vector was digested with different restriction enzymes to verify the presence and orientation of the cloned fragments. The targeting vector loxP-Pelo-Neo-loxP-TK was linearised by XhoI enzyme before transfection into R1 embryonic stem cells. 


\section{A. Clone 16 kb}

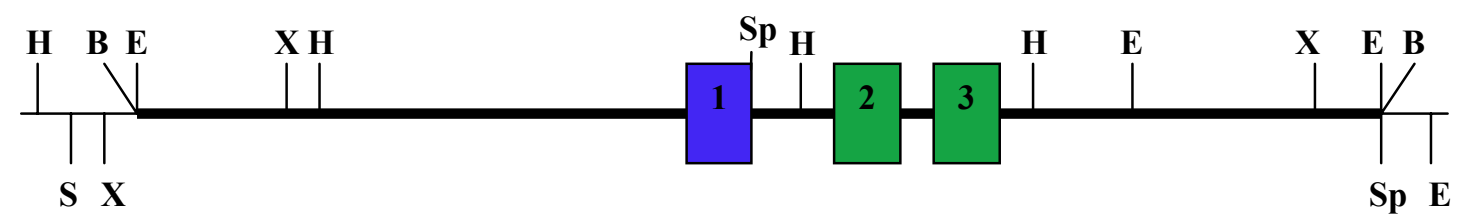

\section{B. Clone 9 kb SpeI}

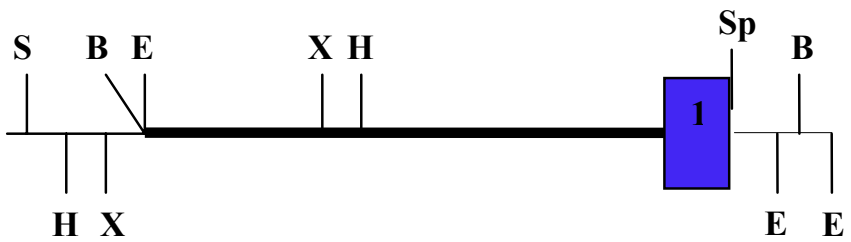

\section{Clone 6 kb SpeI}

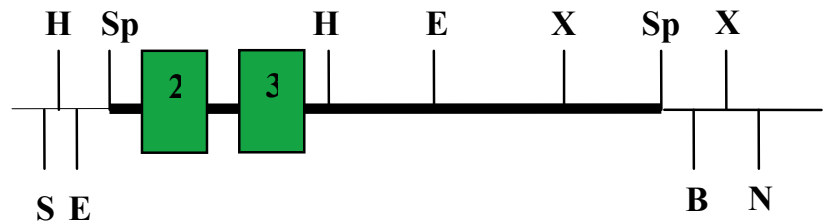

\section{Clone $4 \mathrm{H} / \mathrm{S}$}

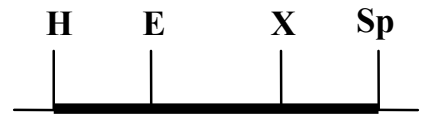

Figure 3.16: A restriction map of Pelo genomic fragment and subclones

A genomic clone (A) containing the $16 \mathrm{~kb}$ genomic fragment of Pelo gene was cloned in pGEM3 vector. A $9 \mathrm{~kb} \mathrm{BamHI/SpeI}$ and $6 \mathrm{~kb}$ SpeI fragment containing the 5' (B) and 3' region of Pelo gene was subcloned in pBluescript and pGEM3 vectors, respectively. The $4 \mathrm{~kb}$ HindIII/SpeI fragment containing the 3 ' flanking region was subcloned in pBluescript vector (D). Restriction sites for following enzymes are shown: B, BamHI; E, EcorI, H, HindIII; S, SalI; Sp, SpeI; X, XbaI; Xh, XhoI; N, NotI; Kp, KpnI. The exons of Pelota gene are shown as blue (E1) and green color (E2 and E3) boxes. 


\section{A. pKSLoxPNT}

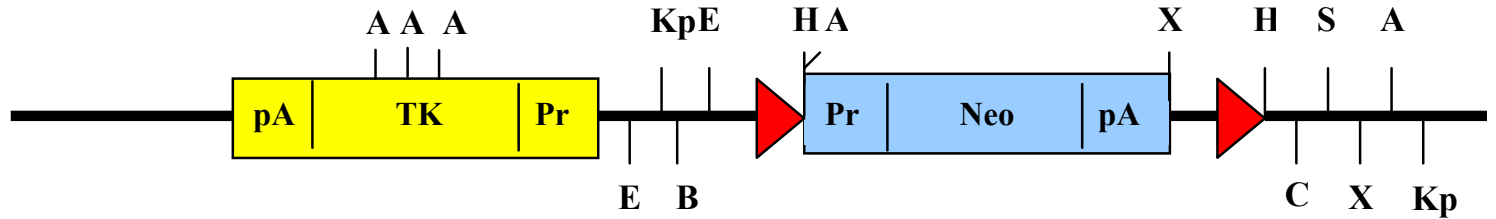

\section{B. Clone 4}

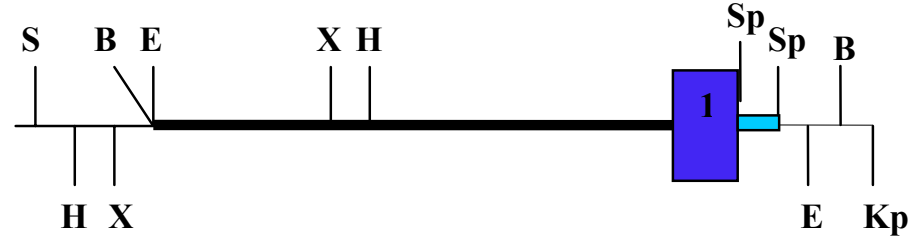

\section{Clone Neo-4H/S}

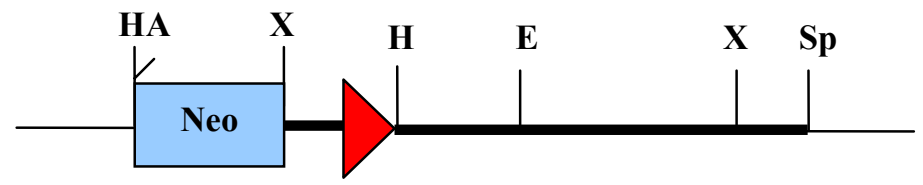

\section{Clone 3}

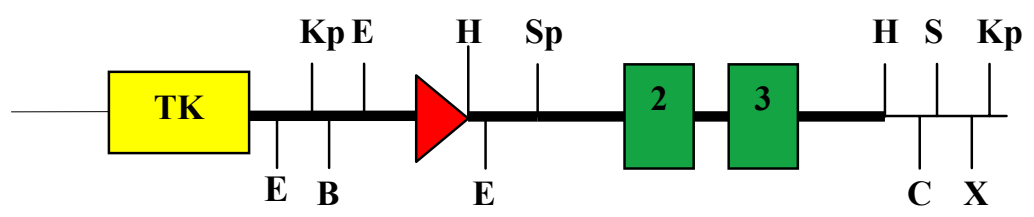

E. Clone 9

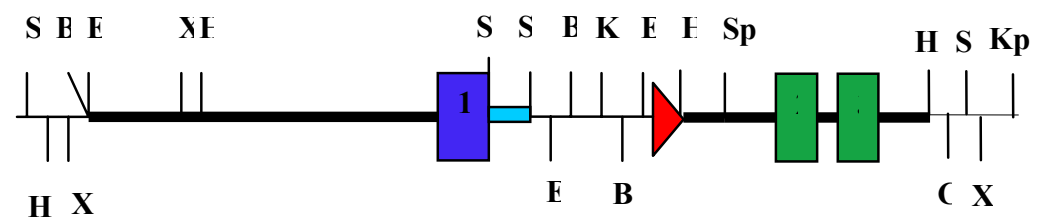

continued to Figure 3.17 


\section{F. Clone 10}

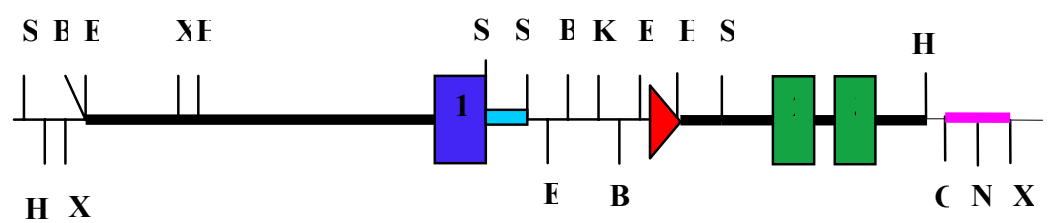

\section{G. Clone 11}

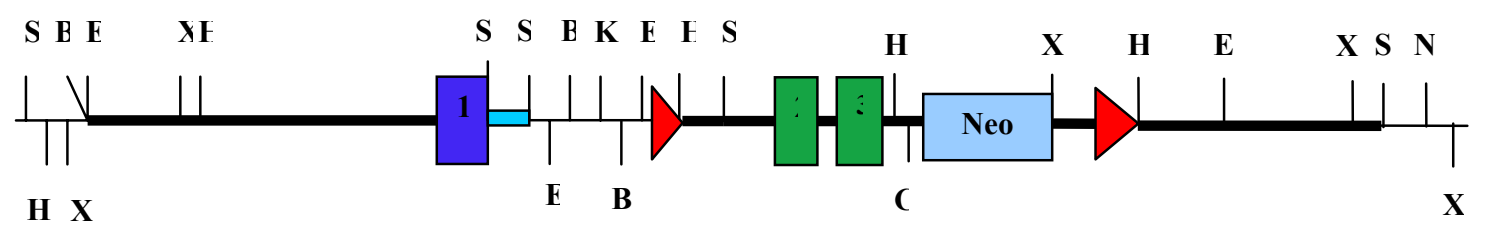

\section{Clone 12}

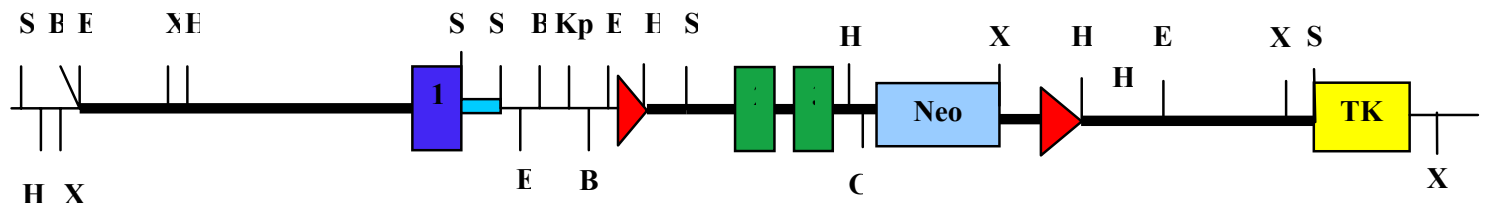

Figure 3.17: Cloning strategy to generate the conditional Pelo targeting allele

A backbone of the pKSLoxPNT vector containing the Neo, TK and loxP cassettes was used for cloning the floxed Pelo construct (A). The $150 \mathrm{bp}$ fragment of the intron 1 was cloned into clone $9 \mathrm{~kb}$ SpeI (Fig $3.16)$ to generate the clone 4 (B). The $2 \mathrm{~kb}$ HindIII fragment of Neo cassette was isolated from the vector and cloned into clone 4H/S (Fig 3.16D) to generate the clone Neo-4H/S (C). The $2 \mathrm{~kb}$ HindIII fragment containing the exon 2 and 3 of Pelo was cloned upstream of the $T K$ cassette, clone 3 (D). The $2 \mathrm{~kb} K p n I$ fragment was isolated from clone 3 and subcloned in KpnI digested clone 4 to give clone 9 (E). An adaptor containing the restriction sites ClaI-NotI-XhoI was cloned in ClaI/XhoI digested clone 9 to give clone 10 (F). The $6 \mathrm{~kb}$ HindIII/SpeI fragment was isolated from clone Neo-4H/S was inserted in HindIII/SpeI digested clone 10 to produce clone 11 (G). Finally, the Neo/XhoI fragment containing TK cassette was cloned into NotI/XhoI digested clone 11 to produce the final targeting construct, clone 12 (I). Restriction sites are shown as letters, loxP sites are in red, 150-bp fragment is in light blue, ClaI-NotIXhoI oligonucleotide adaptor is in pink. The cloned fragments are shown as bold bars. 


\subsubsection{Generation of 5' external probe}

A 5' external probe was generated and used as a hybridisation probe for Southern blot analysis to distinguish between wildtype $\left(\mathrm{Pelo}^{+}\right)$and floxed $\left(\right.$Pelo $\left.{ }^{f l o x}\right)$ alleles (Fig 3.18I; III; V). For this purpose, 568 bp fragment located in the 5' flanking region of the Pelota gene was amplified by PCR assay using Pelo.5'-F1 and Pelo.5'-R1 primers and genomic DNA as a template. The PCR products were subcloned in pGEMTeasy vector and subsequently sequenced. The $568 \mathrm{bp}$ EcoRI fragment was purified and used as a 5' external probe for Southern blots with genomic DNA extracting from recombinant ESclones.

\subsubsection{Generation of an internal probe}

The $1.0 \mathrm{~kb}$ EcoRI/HindIII fragment was isolated from clone 6-kb SpeI (Fig 3.16C) and inserted into the EcoRI/HindIII site of pBlueScript vector to produce clone $1.0 \mathrm{~kb} \mathrm{E} / \mathrm{H}$ probe (Fig 3.18III; IV). The DNA of the clone $1.0 \mathrm{~kb} \mathrm{E} / \mathrm{H}$ was then double digested with EcoRI/HindIII, the $1.0 \mathrm{~kb}$ fragment was extracted from the agarose gel and used as an 3' internal probe for Southern blot hybridisation with genomic DNA extracted from tail biopsies, tissues and mouse embryonic fibroblasts. 
I. Wildtype allele $\left(\mathrm{Pelo}^{+}\right)$

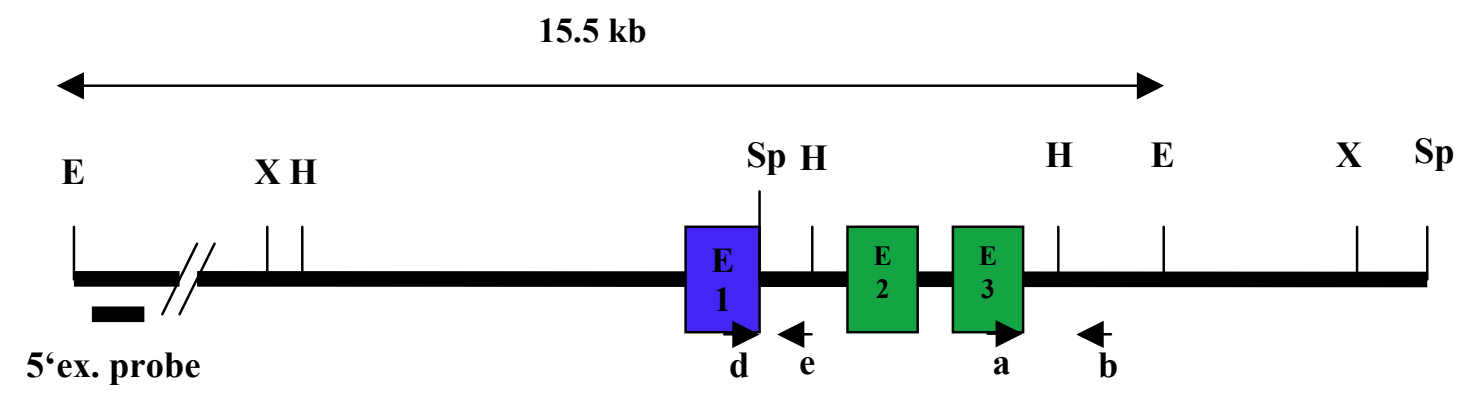

II. Targeting vector



III. Floxed allele (Pelo $\left.{ }^{f l o x}\right)$

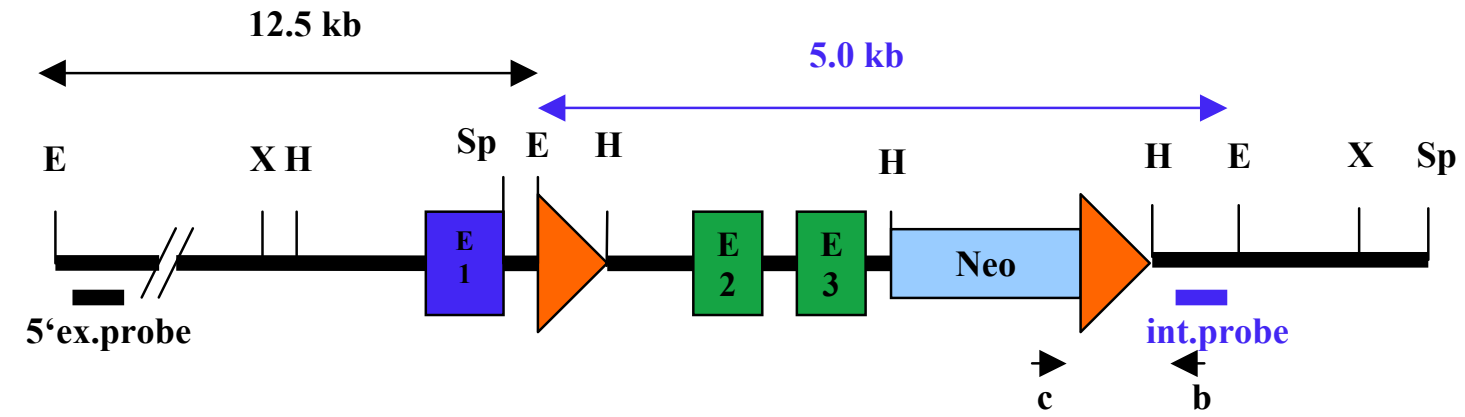

continued to Figure 3.18 


\section{Deleted allele $\left(\mathrm{Pelo}^{\Delta}\right)$}

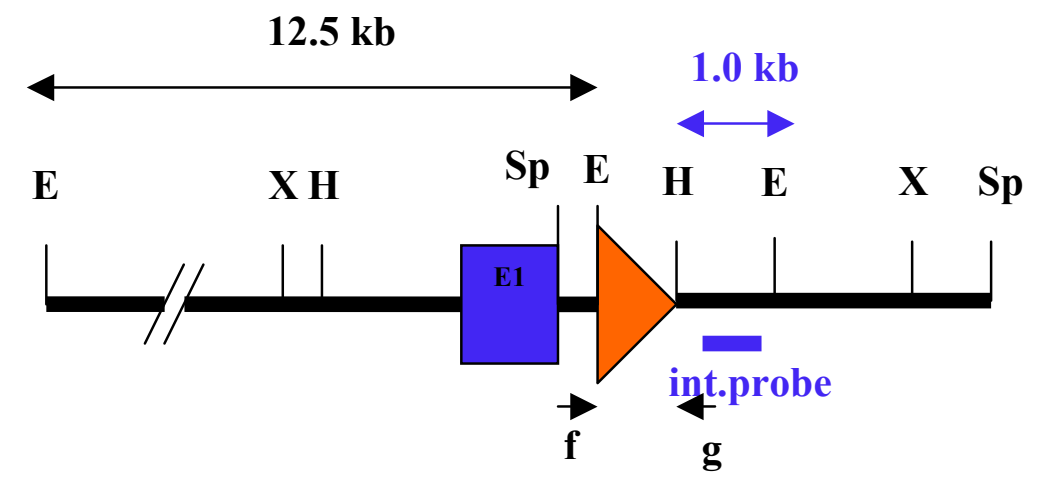

V. Mutant allele (Pelo-)

\section{$12.5 \mathrm{~kb}$}

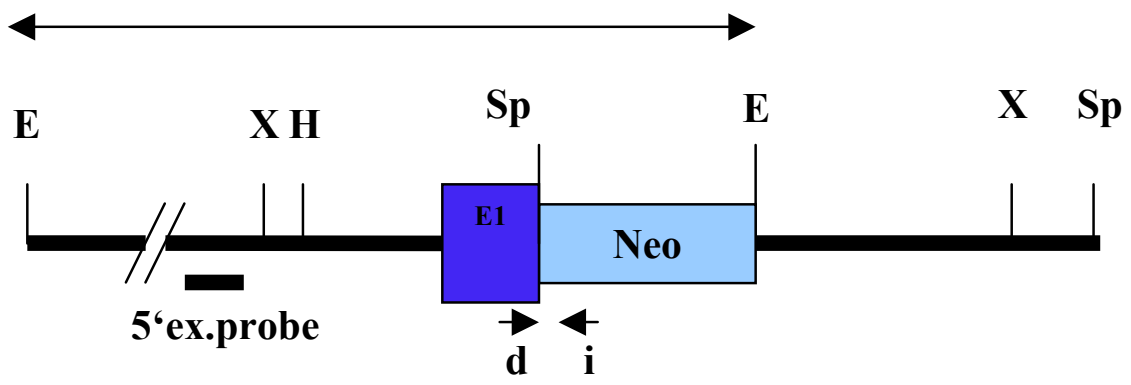

Figure 3.18: Schematic representation of the different Pelo alleles

A restriction map of the wildtype allele (I), targeting vector (II), Pelo ${ }^{\text {flox }}$ allele (III), deleted allele (IV) and conventional Pelo knockout allele (V) are shown. The primers a, b and $\mathbf{c}$ used to amplify the wildtype and floxed alleles are shown in I and III. Primers d, e and $\mathbf{i}$ used to amplify the wildtype and Pelo ${ }^{-}$alleles are shown in I and IV. Primers $\mathbf{f}$ and $\mathbf{g}$ used to amplify the Pelo ${ }^{\Delta}$ allele are shown in IV. The 5' external and internal probes used to detect the predicted length of EcoRI restriction fragment in Southern blot hybridisation are shown in I, III, IV and V. 


\subsubsection{Electroporation and screening of R1 ES cells for homologous recombination}

ES cell line R1 was cultured in culture medium as described in materials section (2.2.17.1.1-3). Confluent plates were washed in PBS, trypsinised and the cells were suspended in the same buffer at $2 \times 10^{7}$ cells $/ \mathrm{ml}$. Aliquots of ES cell suspension were mixed with $40 \mu \mathrm{g}$ of linearised targeting vector loxP-Pelo-Neo-loxP-TK and electroporated at $240 \mathrm{~V}$ and $500 \mu \mathrm{F}$ using a Bio-Rad Gene Pulser apparatus. The cells were plated onto nonselective medium in the presence of G418-resistant mouse embryonic fibroblasts. After $36 \mathrm{hrs,} \mathrm{selection} \mathrm{was} \mathrm{applied} \mathrm{using} \mathrm{medium} \mathrm{containing}$ G418 at $400 \mu \mathrm{g} / \mathrm{ml}$ and gancyclovir at $2 \mu \mathrm{M}$. After 10 days of selection, totally $\sim 800$ individual drug-resistant clones from all transfections were picked into 24 -well plates for freezing and isolation of DNA.

Targeted integration into the Pelota gene was verified by Southern blot analyses using the hybridisation probe located 5' to the targeting construct (Fig 3.18). As expected for homologous recombination event (Fig 3.18), the $5^{\prime}$ external probe recognized $15.5 \mathrm{~kb}$ wildtype $\left(\mathrm{Pelo}^{+}\right)$and $12.5 \mathrm{~kb}$ floxed $\left(\right.$ Pelo $\left.^{\text {flox }}\right)$ alleles. Of the approximately $800 \mathrm{ES}$ clones screened, 3 clones had undergone correct homologous recombination (Fig 3.19).

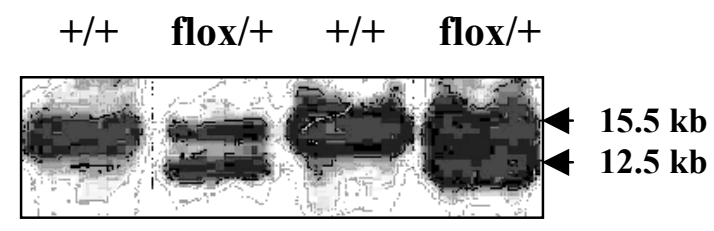

Figure: 3.19: The screening of ES cells for homologous recombination

Southern blot analyses was performed using 5' external probe. ES cell DNA was digested with EcoRI. The $0.5 \mathrm{~kb}$ external probe detects $15.5 \mathrm{~kb}$ wildtype and $12.5 \mathrm{~kb}$ floxed alleles. 


\subsubsection{Generation of chimeric mice}

The homologous recombinant ES cells were injected into $3.5 \mathrm{dpc}$ blastocysts derived from C57BL/6J mice. The blastocysts were transferred into pseudopregnant CD-1 mice to generate chimeric mice. This work was performed in the MPI for experimental Medicine, Göttingen. ES cells of clones No123 and 127 yielded 7 male and 3 female chimeras, in which the chimerism ranged from $10-85 \%$. None of these male and female chimeras transmitted the targeted gene through their germline. Therefore, ES cells of clone No29 were used to generate chimeric mice. Two high percent male chimeras (90\% and 95\%) were generated and bred with $\mathrm{C} 57 \mathrm{BL} / 6 \mathrm{~J}$ female mice to obtain $\mathrm{F} 1$ animals. Both chimeric males transmitted the targeted gene through their germline producing heterozygous animals. To determine the genotype of F1 generation, we performed PCR assay with primers a, b and c (Fig 3.18), which amplify 550 bp fragment of floxed allele Pelo flox and $450 \mathrm{bp}$ fragment of wildtype allele $\mathrm{Pelo}^{+}$(Fig 3.20A). Heterozygous Pelo ${ }^{\text {flox/+ }}$ are viable, fertile and show no abnormalities. Breeding of heterozygous animals yielded homozygous Pelo ${ }^{\text {flox/flox }}$ mice. These animals are normal and fertile. These results demonstrate that the insertion of the loxP sites and neomycin cassette $(\mathrm{Neo})$ in intron 1 and 3' flanking region does not affect the function of Pelota gene. 
A

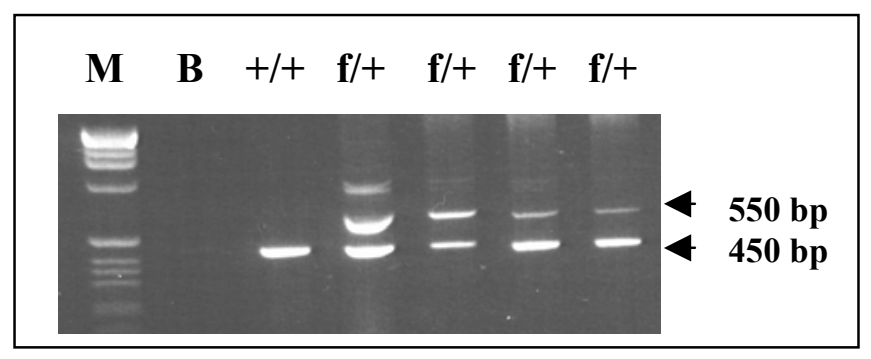

B

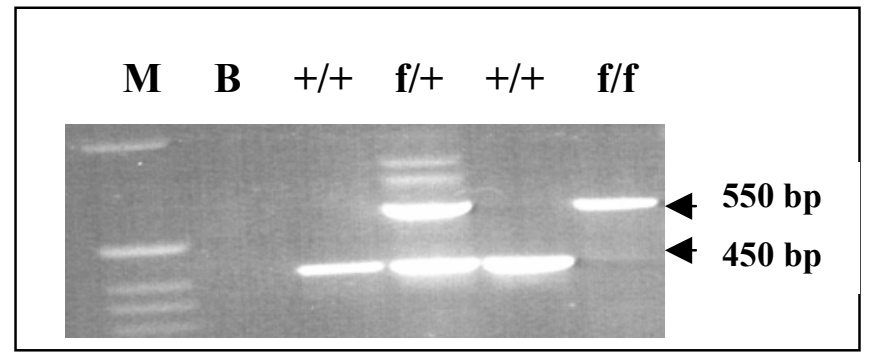

Figure 3.20: PCR genotyping for floxed Pelo allele

The wildtype allele for Pelo is amplified by PelocKO-F and PelocKO-R primers resulting in a PCR product of about $450 \mathrm{bp}$. The floxed Pelo allele generated a fragment of 550 bp by using the PGK1 and PelocKO-R primers. The PCR products were separated on 1.5\% agarose gel and stained with EtBr. B, blank control, no DNA template; +, wildtype allele; f, floxed allele. 


\subsubsection{Generation of non-inducible conditional knockout mice}

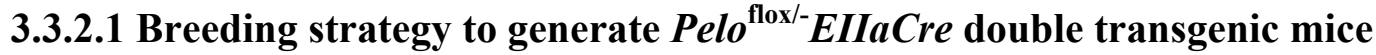

Several Cre-fusion alleles were used to catalyse the excision of DNA flanked by loxP sequences in cell culture or in vivo (Jonkers and Berns, 2002; Branda and Dymecki, 2004). Tissue specific promoters were used to restrict Cre activity to the cell type of interest. Inducible Cre expression and expression of ligand-dependent Cre recombinases were utilised to induce time-controlled specific DNA arrangements (Brocard et al., 1997; Metzger and Chambon, 2001).

In 1989, Dooley et al. found that the adenovirus EIIa promoter is active in the oocyte prior to and for a short time after fertilisation. In 1996, Lakso et al. utilised this information to generate a transgenic mouse in which the adenovirus EIIa promoter directed the action of Cre recombinase gene to the single-cell zygote. This is a practical approach towards deleting DNA sequences between loxP sites from all cells of a developing embryo, provided that $C r e$ indeed excises the target DNA sequence when the embryo is still at the one-cell zygote stage. If so, then all cells of the developing animal will lack the specified DNA sequence, including germ line cells that give rise to progeny of these mice.

To determine whether DNA sequences between loxP sites can be excised by Cre recombinase, EIIaCre transgenic allele was introduced in the genome of mice that harbour the floxed Pelo (Pelo ${ }^{\text {flox }}$ ) and the conventional targeted allele (Pelo-) (Adham et al., 2003). The reason to introduce EIIaCre allele in the genome of Pelo ${ }^{\text {flox/- }}$ but not in that of Pelo ${ }^{\text {flox/flox }}$ is due to results which have shown that Cre activity in some cells can only excise DNA sequences between loxP sites of one floxed allele and yield heterozygous Pelo ${ }^{\text {flox/ }}$ cells.

To generate the Pelo ${ }^{\text {flox/- }}$ EIIaCre mice, we did two intercrosses between Pelo ${ }^{\text {flox } /+}$ males with Pelo ${ }^{+/+}$EIIaCre females and between $\mathrm{Pelo}^{+/-}$males with Pelo ${ }^{+/+}$EIIaCre females (Fig 3.21). Genotyping of the offsprings was performed by PCR assay (Fig 3.22).

According to transactivation of the adenovirus EIIa promoter in the oocyte (Dooley et al., 1989), we have expected that the recombination of the floxed allele in the 
Pelo ${ }^{\text {flox } /+}$ EIIaCre occurs in F1 generation. However, PCR analysis revealed that 20 out 60 analysed animals were chimeras for Pelo ${ }^{\text {flox } /+}$ EIIaCre and Pelo ${ }^{\Delta /+}$ EIIaCre genotypes.

To determine the efficiency of recombination, Southern blot with EcoRI digested DNA was hybridised with the internal probe (Fig 3.18) which recognises the $15.5 \mathrm{~kb} \mathrm{Pelo}{ }^{+}$, $5.0 \mathrm{~kb} \mathrm{Pelo}{ }^{\text {flox }}$ and $1.0 \mathrm{~kb} \mathrm{Pelo}{ }^{\Delta}$ deleted alleles. As shown in Figure $3.23 \mathrm{~A}$, the efficiency of deletion of Pelo ${ }^{\text {flox }}$ allele in Pelo flox/+ animal No1 is higher than in animal No2. These results demonstrate that the Pelo flox/+ EIIaCre double transgenic mice show variable degrees of mosaicism, which is due to partial Cre-mediated recombination of floxed allele. These results suggest that Cre-mediated recombination of floxed allele did not completely occur in the 1-cell stage.

The Pelo ${ }^{\text {flox/+ }}$ EIIaCre females and Pelo ${ }^{+/}$EIIaCre males from F1 generation were bred

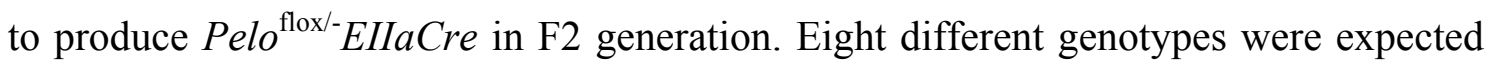
in F2 generation: Pelo ${ }^{\text {flox/+}}$ EIIaCre, Pelo ${ }^{\text {flox/- EIIaCre, Pelo }}{ }^{+/+}$EIIaCre, Pelo ${ }^{+/-}$EIIaCre, Pelo $^{\text {flox } /+}$, Pelo flox/-, Pelo ${ }^{+/+}$and Pelo ${ }^{+/}$. Except the genotypes Pelo ${ }^{\text {flox } /+}$ EIIaCre and

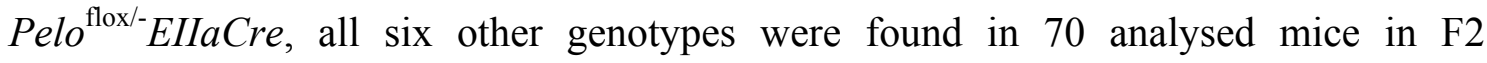
generation. Genotyping of those mice using PCR assay with primers f and g (Fig 3.18), which amplified deleted allele Pelo $^{\Delta}$, resulted in 8 Pelo $^{\Delta /+}$ EIIaCre mice. In contrast, Pelo $^{\Delta /-}$ EIIaCre could be identified among 70 analysed animals of F2 generation. To verify the targeted deletion of Pelota in all cells of Pelo ${ }^{\Delta /+}$ EIIaCre animals, we performed Southern blot analysis using internal probe. As shown in Figure 3.23B, the probe only recognises the $15.5 \mathrm{~kb} \mathrm{Pelo}^{+}$wildtype and the $1.0 \mathrm{~kb} \mathrm{Pelo}^{\Delta}$ deleted fragments.

Taken together, these results demonstrate the EIIaCre completely recombined floxed allele in F2 generation and this excision might have occurred during gametogenesis and 1-cell stage. Furthermore, the absence of Pelo in F2 generation is due to the embryonic lethality similar to that shown for the conventional knockout mouse (Adham et al., 2003). The complete excision of the floxed Pelo (Pelo flox $)$ allele in Pelo ${ }^{\text {flox/+ }}$ EIIaCre double transgenic mice and embryonic lethality of Pelo ${ }^{\Delta /-}$ EIIaCre clearly showed that the generated Pelo ${ }^{\text {flox }}$ allele can successfully recombine with Cre recombinase in an in vivo system. 


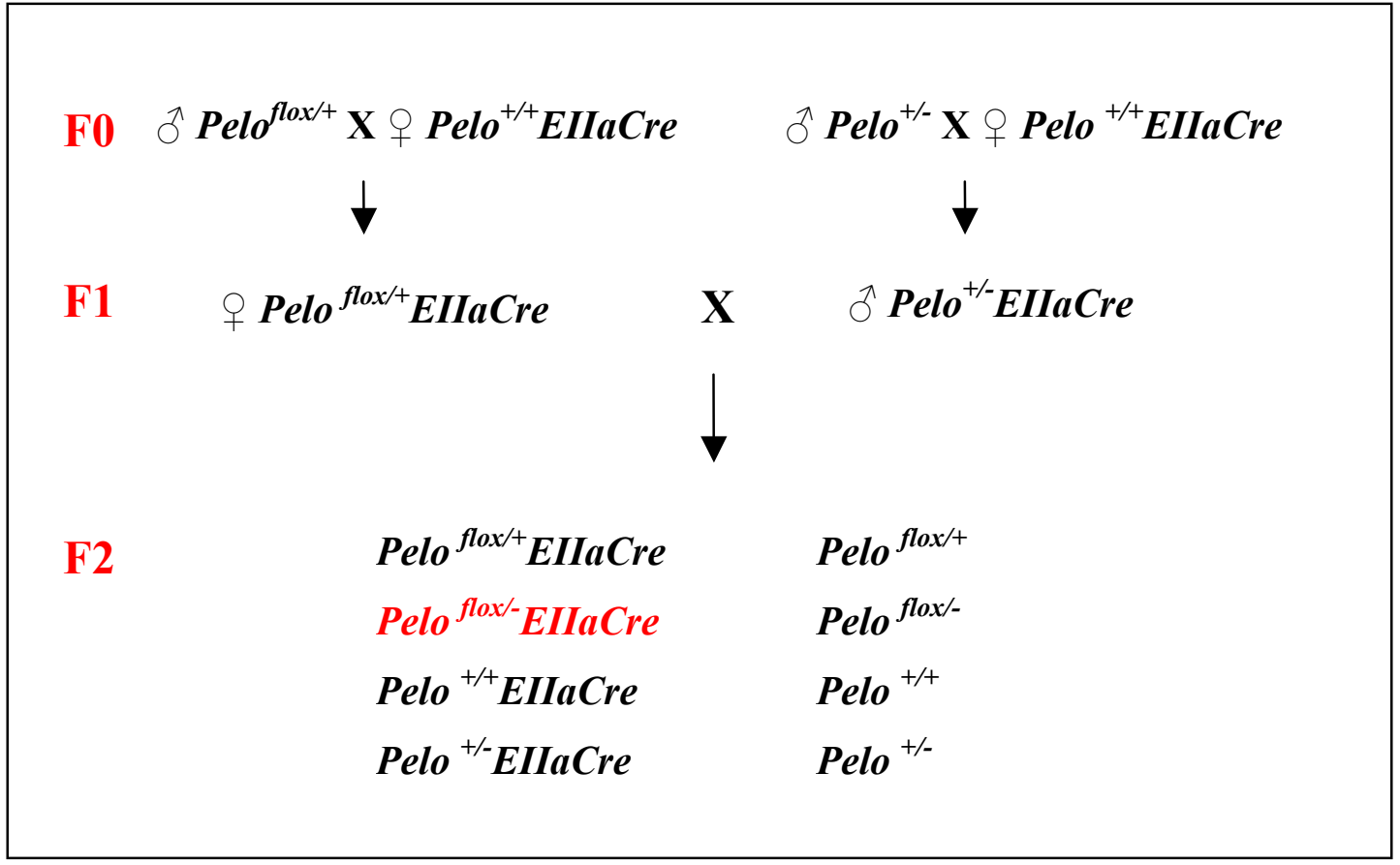

Figure 3.21: Breeding strategy to produce double transgenic mice

Offspring from female $\mathrm{Pelo}^{+/+}$EIIaCre and male floxed mice $\left(P e l o^{\text {flox/ } /+}\right.$ ) were screened for Pelo flox/+ EIIaCre double transgenic mice, while offspring from female Pelo ${ }^{+/+}$EIIaCre and male Pelo ${ }^{+/-}$ were screened for Pelo ${ }^{+/}$EIIaCre in F1 generation. Then, breeding between double transgenic Pelo flox/+ EIIaCre female and Pelo ${ }^{+/}$EIIaCre male (F1) was performed in order to obtain Pelo ${ }^{\text {flox/ }}$ EIIaCre mice in F2 generation. 


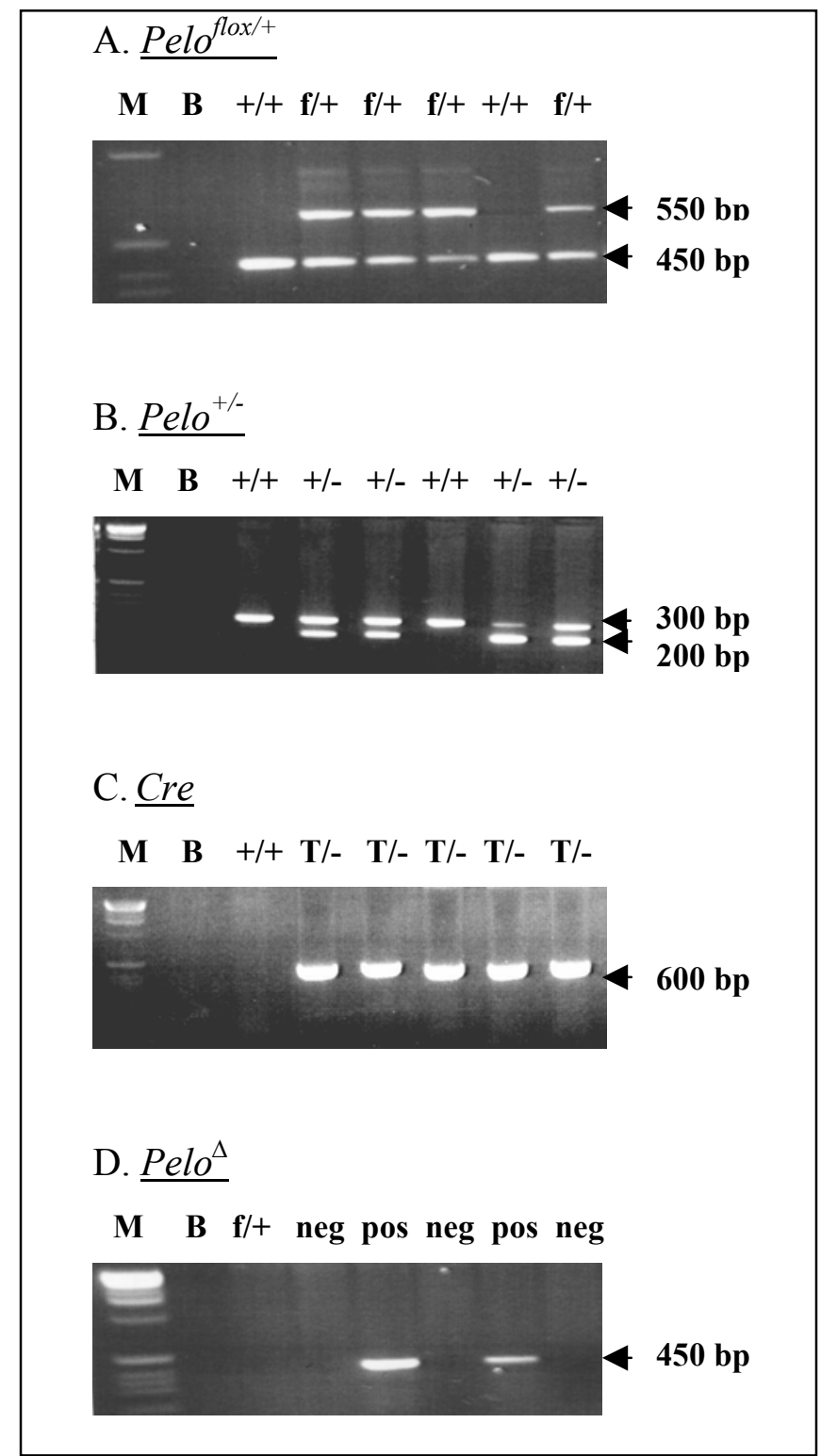

Figure 3.22: Genotyping PCR to identify different alleles of Pelo

The genotypes of mice were determined by PCR amplification of tail DNA. Primers were designed to amplify different alleles of Pelo, particularly, Pelo ${ }^{+}$, Pelo $^{f l o x}, P_{e l o}{ }^{\Delta}$ and Cre. (A) a and $\mathbf{b}$ for the Pelo ${ }^{+}$ (450 bp), c and b for Peloflox (550 bp); (B) d and e for Pelo ${ }^{+}$(300 bp), d and i for Pelo- (200 bp); (D) f and g for Pelo ${ }^{\Delta}(450 \mathrm{bp})$ alleles (Fig 3.18) as well as Cre (600 bp) transgenic allele (C). 


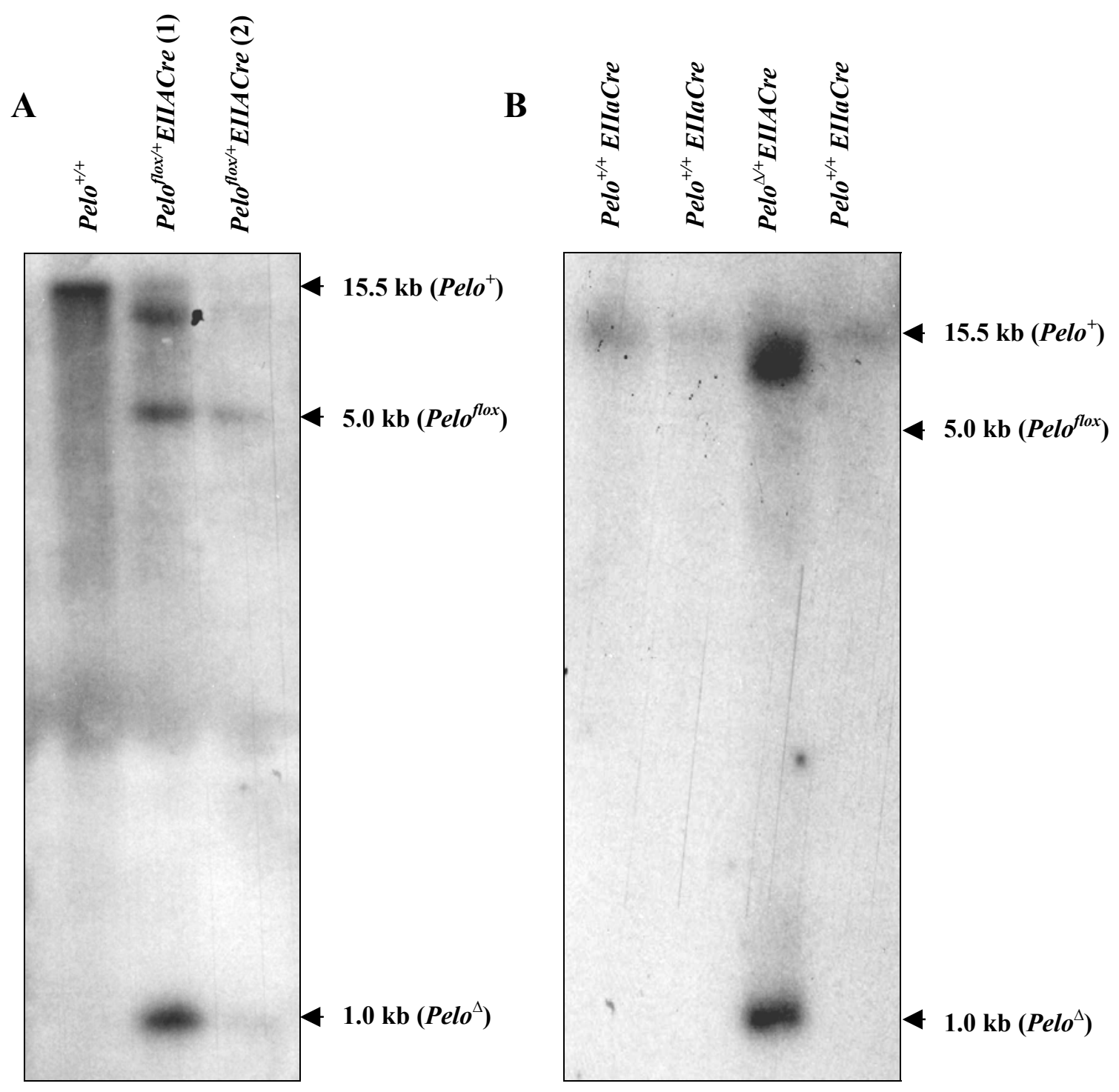

Figure 3.23: Southern blot analysis to evaluate the efficiency of Cre-mediated recombination

A. Lane 1, wildtype as a control. Lanes 2 and 3, Pelo ${ }^{f l o x / t}$ EIIaCre mice in which Cre-mediated recombination has partially occurred producing the genotype $\mathrm{Pelo}^{\Delta /+}$ in F1 generation.

B. Lanes 1, 2 and 4, wildtype as a control. Lane 3, Pelo ${ }^{f l o x / t}$ EIIaCre mice in which Cre-mediated recombination has completely occurred producing the genotype $P e l o^{\Delta /+}$ in F2 generation. 


\subsubsection{Generation of Pelota inducible conditional knockout mice}

\subsubsection{Breeding strategy to generate $P e l o^{f l o x /}-\mathrm{CreER}^{T}$ double transgenic mice}

To achieve temporal inactivation of floxed Pelo allele in vivo, $C r e-E R^{T}$ fusion allele was introduced in the genome of Pelo flox/- mice. In this fusion allele, the Cre recombinase gene is fused with the mutated ligand binding domain of the human estrogen receptor $\left(\mathrm{ER}^{\mathrm{T}}\right)$. The fusion protein become active upon administration of the synthetic estrogen antagonist 4-hydroxytamoxifen (OHT), but not in the presence of the natural ligand 17ß-estradiol (Feil et al., 1996). To avoid the random integration of the CreER ${ }^{T}$ transgenic allele into the mouse genome which often results in mosaic gene expression (Garrick et al., 1998; Henikoff 1998), the $C r e E R^{T}$ fusion gene was inserted into the ubiquitously expressed ROSA26 (R26) locus by gene targeting (Voojis et al., 2001). The R26CreER ${ }^{\mathrm{T}}$ is expressed throughout mouse development and in adult life, but Cre recombinase only become active after administration of the OHT or tamoxifen (TAM).

To determine the efficiency of the ligand-dependent Cre recombinase $\left(\mathrm{CreER}^{\mathrm{T}}\right)$ for excision of Pelo ${ }^{f l o x}$ after administration of the ligand, 9 males and 1 female Pelo ${ }^{\text {flox }}$ $\mathrm{CreER}^{T}$ mice were injected intraperitoneally (i.p) for 5 consecutive days with $2 \mathrm{mg}$ of TAM. The controls, 3 males and 2 females Pelo $^{+/+} \mathrm{CreER}^{T}$ animals were also treated.

\subsubsection{Fertility test of the TAM-treated mice}

To check the fertility, we crossed the animals with wildtype CD-1 mice one month after TAM administration. As shown in Table 3-1, 6 Pelo $^{\text {flox/- }} \mathrm{CreER}^{T}$ male mice were subfertile and 3 Pelo $^{f l o x /}{ }^{-} \mathrm{CreER}^{T}$ male mice were fertile. The wildtype TAM-treated control animals $\left(\right.$ Pelo $\left.^{+/+} \mathrm{CreER}^{T}\right)$ were fertile. One treated female died 10 days after treatment, while the other Pelo ${ }^{f l o x /}{ }^{-}{ }_{r} E E R^{T}$ and wildtype females are fertile. 


\begin{tabular}{|c|c|c|c|}
\hline $\begin{array}{c}\text { No. of } \\
\text { mice }\end{array}$ & Sex & Genotype & Littersize \\
\hline 26 & $\sigma^{\lambda}$ & Pelo $^{\text {flox/- }}$ CreER $^{T}$ & 4 \\
\hline 51 & $\hat{\sigma}$ & Pelo $^{\text {flox/- }}$ CreER $^{T}$ & 2 \\
\hline 79 & o & Pelo $^{\text {flox/-}}$ CreER $^{T}$ & 3 \\
\hline 78 & $\sigma^{\lambda}$ & Pelo ${ }^{\text {flox/- }}$ CreER $^{T}$ & 3 \\
\hline $68 \mathrm{~A}$ & $\sigma^{\lambda}$ & Pelo ${ }^{\text {flox/- }}$ CreER $^{T}$ & 3 \\
\hline $73 \mathrm{~A}$ & $\hat{\sigma}$ & Pelo $^{\text {flox/-}}$ CreER $^{T}$ & 3 \\
\hline 40 & $\sigma^{\lambda}$ & Peloflox/-CreER ${ }^{T}$ & 13 \\
\hline 68 & $\hat{\sigma}$ & Pelo $^{\text {flox/- }}$ CreER $^{T}$ & 17 \\
\hline 45 & $\widehat{\sigma}$ & Pelo $^{\text {flox/- }}$ CreER $^{T}$ & 13 \\
\hline 43 & $\hat{\sigma}$ & Pelo $^{+/+}$CreER $^{T}$ & 13 \\
\hline 76 & $\sigma^{\lambda}$ & Pelo $^{+/+} \mathrm{CreER}^{T}$ & fertile \\
\hline 69 & o & Pelo $^{+/+}$CreER $^{T}$ & 14 \\
\hline 54 & q & Pelo $^{\text {flox/- }}$ CreER $^{T}$ & died \\
\hline 37 & q & Pelo $^{+/-} \mathrm{CreER}^{T}$ & fertile \\
\hline 39 & q & Pelo $^{+/+}$CreER $^{T}$ & fertile \\
\hline
\end{tabular}

Table 3-1: Fertility test of TAM-treated mice bred with wildtype animals

To investigate the cause of infertility and to determine the efficiency of deletion of floxed allele in some tissues in vivo, including testis, spleen, stomach and kidney were isolated from three subfertile Pelo ${ }^{\text {flox/ }}{ }^{-} \mathrm{CreER}^{T}$ males (No26, 51 and 79) and from two control Pelo ${ }^{+/+} \mathrm{CreER}^{T}$ males.

One month after administration of TAM, testis size of Pelo ${ }^{\text {flox/- }} \mathrm{CreER}^{T}$ mice was drastically reduced as compared to TAM-treated $\mathrm{Pelo}^{+/+} \mathrm{CreER}^{T}$ control mice (Fig 3.24). 


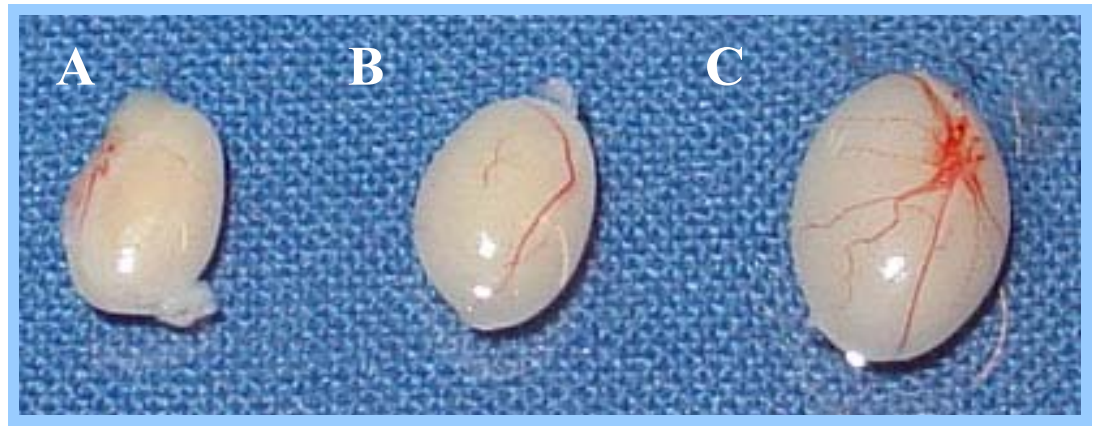

Figure 3.24: The phenotypic alteration of testis from TAM-treated Pelo $^{\text {flox/- }} \mathrm{CreER}^{T}$ animals

The testis size is severely reduced in TAM-treated Pelo ${ }^{f l o x /}{ }^{-}{ }_{r e E R}{ }^{T}$ No26 and 79 mice (A and B) as compared with TAM-treated Pelo ${ }^{+/} \mathrm{CreER}^{T}$ control mouse (C) at 3 months of age.

\subsubsection{Histological analysis of TAM-treated mice}

Histological analysis of Pelo ${ }^{\text {flox/ }} \mathrm{CreER}^{T}$ testes from TAM-treated mice revealed extensive degeneration of a large fraction (20-60\%) of seminiferous tubules of mutant animals No26 and 51, while depletion of germ cells in testes of mutant animals No79 was less apparent (Fig 3.25). Whereas testes of TAM-treated $\mathrm{Pelo}^{+/+} \mathrm{CreER}^{T}$ control mice demonstrated robust spermatogenesis, the affected fractions of seminiferous tubules of mutant testes from animals No26 and 51 showed markedly reduced late meiotic (i.e late pachytene and diplotene spermatocytes) and postmeiotic (i.e spermatids and spermatozoa) germ cells and contained significant vacuolisation. This vacuolisation is caused by severe germ cell depletion through endocytosis. 

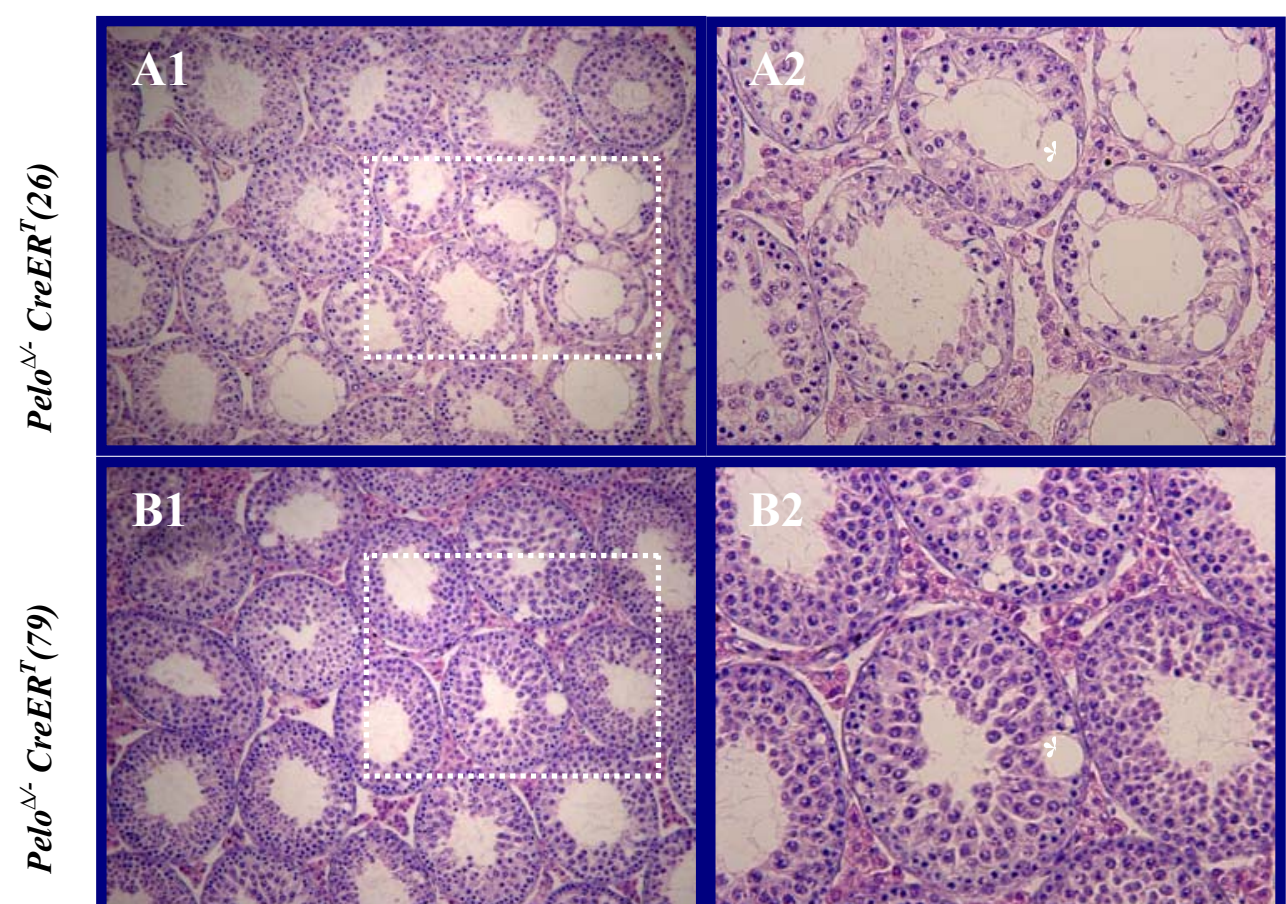

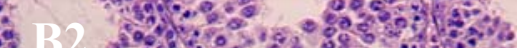

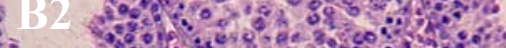

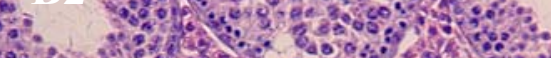

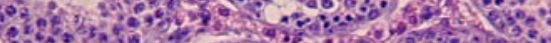



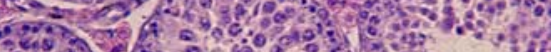

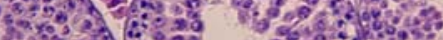
1. $10 \%$ o. $3018 \%$.

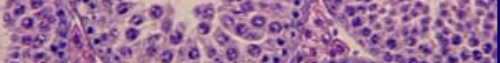

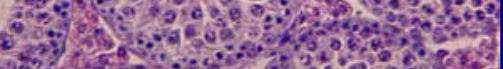

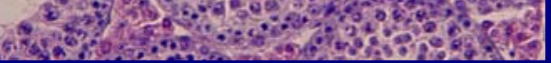
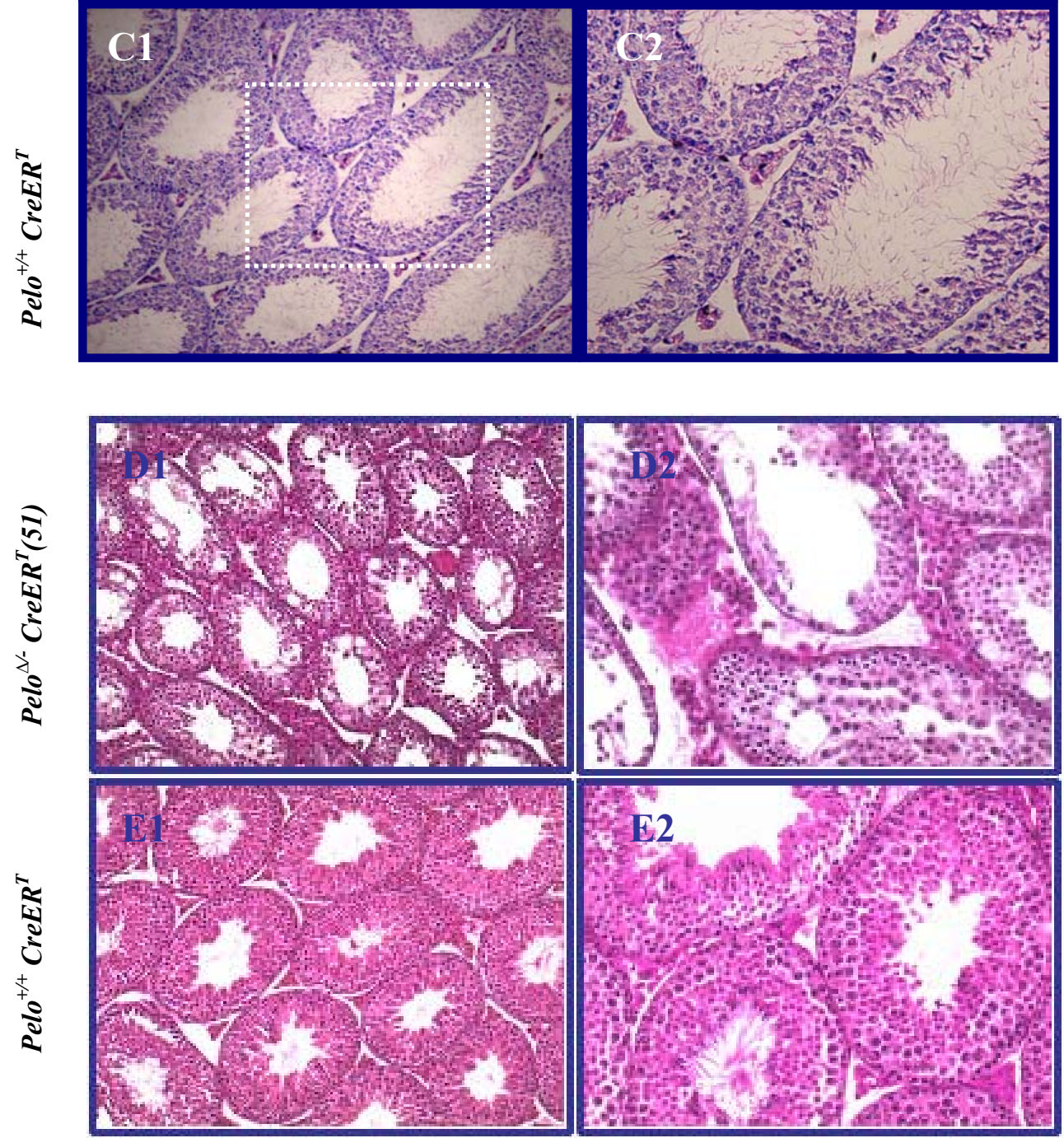
Figure 3.25: Hematoxylin-eosin (H\&E) staining of sections of TAM-treated Pelo ${ }^{f l o x}-\mathrm{CreER}^{T}$ testes

Sections through testis demonstrate tubules of smaller diameter, dilated vacuoles (asterisk), and drastic reduction of spermatogenic cells in the Pelo ${ }^{\Delta /-} \mathrm{CreER}^{T}$ mutant mice No: 26, 79 and 51 (A1, B1 and D1) in contrast to Pelo ${ }^{+/+} \mathrm{CreER}^{T}$ males as control (C1 and E1). A2, B2, C2, D2 and E2: Higher-magnification images corresponding to the boxed areas in A1, B1, C1, D1 and E1, respectively.

\subsubsection{Immunohistochemical analysis of testis sections of TAM-treated Pelo ${ }^{f l o x}$ - CreER ${ }^{T}$ mice}

To further confirm our histological findings, we investigated whether the depletion of germ cells in testes of $\mathrm{Pelo}^{\Delta /-} \mathrm{CreER}^{T}$ mice is due to the defect in spermatogonia or due to the arrest of germ cells in later stages. For these experiments, we analysed the expression of Apg2 which is a marker for spermatogonia. By immunohistochemical analysis, we detected numerous Apg2 positive spermatogonia in TAM-treated Pelo ${ }^{\text {flox- }}$ CreER ${ }^{T}$ testis (Fig 3.26) whereas the number of Apg2 positive spermatogonia varied among the seminiferous tubules of mutant testes.

Taken together, these analyses show that the depletion of germ cells in TAM-treated Pelo $^{\text {flox/- }} \mathrm{CreER}^{T}$ animals is not uniform in all seminiferous tubules and the degree of germ cell damage varies between TAM-treated mutants. This observed variability may be due to the fact that the ligand-dependent Cre recombinase $\left(\mathrm{CreER}^{\mathrm{T}}\right)$ does not efficiently delete the floxed allele in all germ cells. This means that TAM-treated Pelo $^{\text {flox/- }} \mathrm{CreER}^{T}$ mice are chimera for Pelo ${ }^{\Delta /-}$ and Pelo ${ }^{f l o x /}$ cells. 

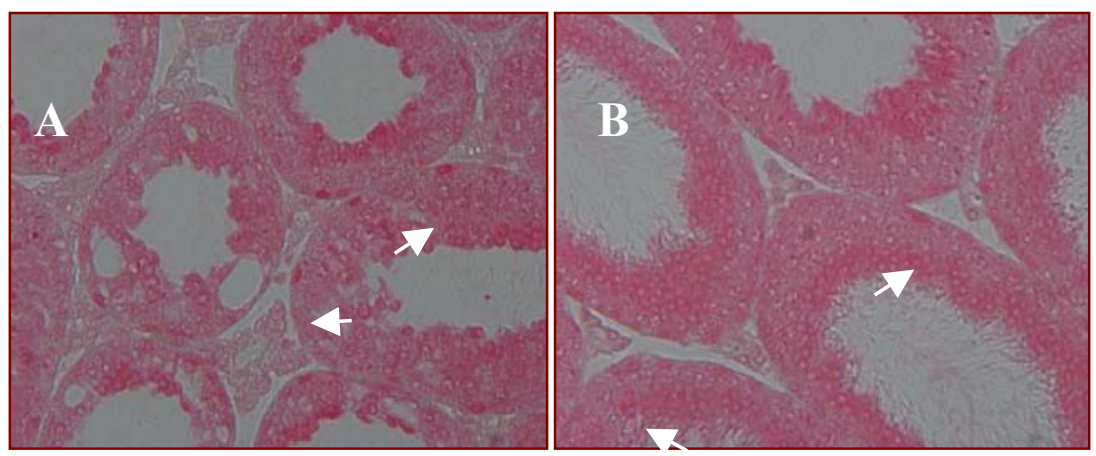

Figure 3.26: Apg2 expression in TAM-treated Pelo $^{f l o x} /{ }_{-} \mathrm{CreER}^{T}$ mice

Immunohistochemical analysis on sections through testes of $\operatorname{Pelo}^{\Delta /-} \mathrm{CreER}^{T}$ (A) and $\mathrm{Pelo}^{+/+} \mathrm{CreER}^{T}$ (B) was performed with anti-Apg 2 antibody show tubules of smaller diameter, dilated vacuoles and germ cell damage. Arrows indicate spermatogonia.

\subsubsection{The efficiency of TAM-induced recombination of $\operatorname{Pelo}^{\text {flox }}$ by $\mathrm{CreER}^{T}$}

To address whether TAM-treated Pelo ${ }^{\text {flox/ }}{ }^{-} \mathrm{CreER}^{T}$ animals are mosaics, Southern blot was performed with EcoRI digested DNA extracted from spleen, kidney and tail of three treated mutant animals No51, 79 and 26. The blots were hybridised with the internal probe that recognises the floxed $\left(\right.$ Pelo $\left.^{f l o x}\right)$ and the deleted $\left(\right.$ Pelo $\left.^{\Delta}\right)$ alleles. As shown in Figure 3.27, the efficiency of deletion in spleen was higher than that in kidney and tail of mice. 


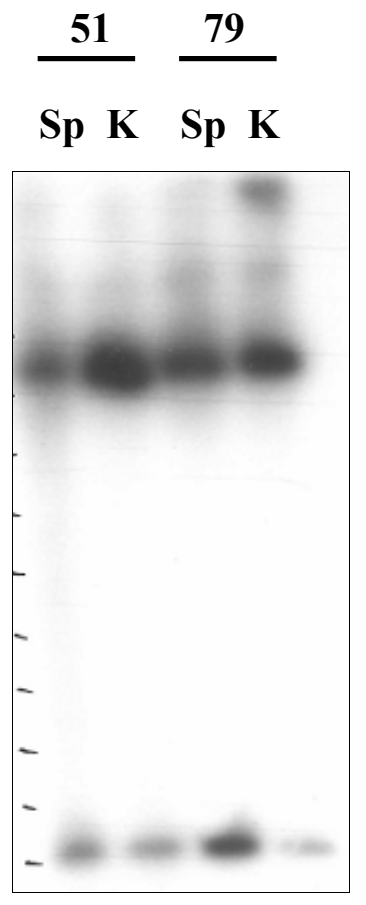

\section{Sp K Tail}

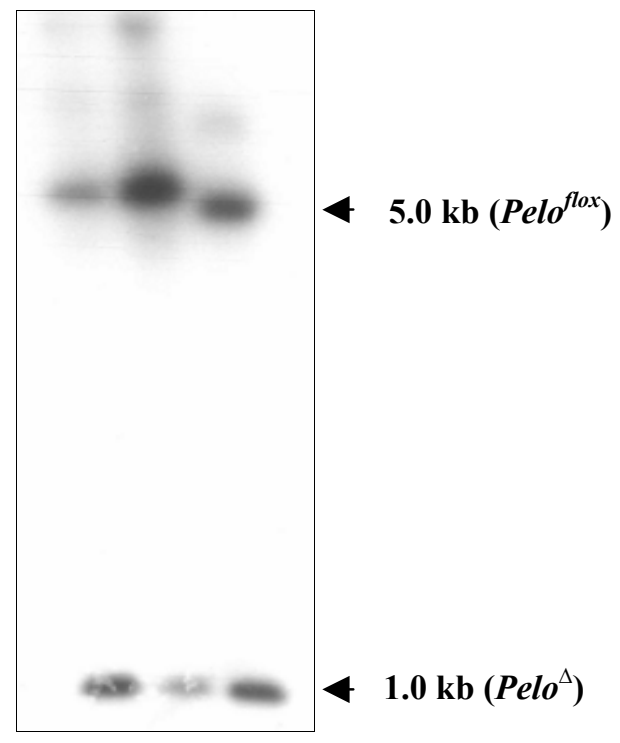

Figure 3.27: TAM-induced recombination of Pelo $^{\text {flox }}$ allele in adult organs

Southern blot analysis of EcoRI digested genomic DNA isolated from spleen and kidney of Pelo flox/$\operatorname{CreER}^{T}$ mice (No51, 79 and 26) treated with 2mg/day TAM for 5 consecutive days. According to Southern blot strategy (Fig 3.18) the expected sizes of fragments that hybridise to the ${ }^{32} \mathrm{P}-$ labeled DNA fragment of $900 \mathrm{bp}$ internal probe are indicated the corresponding floxed allele $\left(\right.$ Pelo $\left.^{\text {flox }}\right)$ and deleted allele $\left(\right.$ Pelo $\left.^{\Delta}\right)$. Sp, spleen; K, kidney.

\subsubsection{Protein study in the testes of TAM-treated $\mathrm{Pelo}^{f l o x /}{ }^{-} \mathrm{CreER}^{T}$ mice}

Western blot analysis was performed with the proteins extracted from testes of TAMtreated Pelo ${ }^{\text {flox } /-} \mathrm{CreER}^{\mathrm{T}}$ No26 and 79 as well as from Pelo ${ }^{+/+} \mathrm{CreER}^{\mathrm{T}}$ control animals. This blot was probed with anti-Pelo antibody. As shown in Figure 3.28, the level of Pelo protein in testis of animal No26 is markedly reduced (80\%) as compared to control animal. The level of Pelo protein in testis of animal No79 is slightly reduced. The reduction of Pelo protein in testes of animals No26 and 79 correlates with the observed damage of germ cells in testes of animals (Fig 3.25), where the depletion of germ cells in testis of animal No26 was significantly higher than in testis of animal No79. 


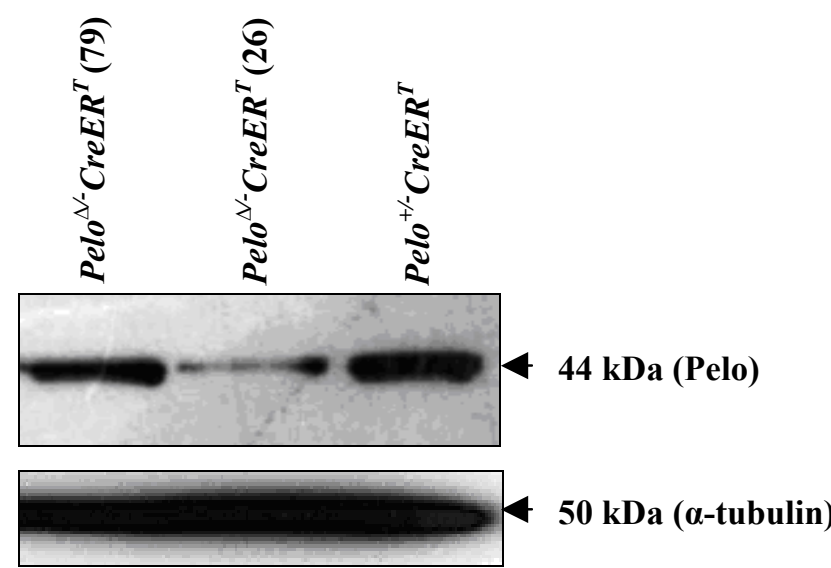

Figure 3.28: Expression of Pelo in testes of TAM-treated animals

Western blot with protein extracting from testes of TAM-treated Pelo $^{\Delta /}{ }^{-}$CreER ${ }^{T}$ mice (No79 and No26) and Pelo ${ }^{+/} \mathrm{CreER}^{T}$ mice (control) was probed with anti-Pelo antibody. The level of Pelo protein in testes of $\mathrm{Pelo}^{\Delta /-} \mathrm{CreER}^{T}$ (No26) is markedly reduced (80\%) as compared to control, while the level of Pelo in animal No79 is slightly reduced. A monoclonal antibody against $\alpha$-tubulin was used as a loading control.

\subsubsection{The effect of Pelota deficiency on cell proliferation}

To study the consequences of Pelota deficiency on cell proliferation, mouse embryonic fibroblasts (MEFs) were isolated from Pelo ${ }^{f l o x /} \mathrm{CreER}^{T}$ and $\mathrm{Pelo}^{+/+} \mathrm{CreER}^{T}$ embryos. Pelo ${ }^{\text {flox/+ }} \mathrm{CreER}^{T}$ male and Pelo $^{+/-}$female animals were crossed and embryos were isolated at E13.5. Fibroblasts were cultured from each embryo as described in methods section (2.2.16.4), DNA was extracted from head of each embryo and used for genotyping. During the fibroblasts culture, we genotyped the embryos and found two Pelo $^{\text {flox/- }} \mathrm{CreER}^{T}$ embryos. Fibroblasts of Pelo ${ }^{\text {flox/- }} \mathrm{CreER}^{T}$ and $\mathrm{Pelo}^{+/+} \mathrm{CreER}^{T}$ (control) were frozen and used for further experiments.

We tested firstly whether conditional floxed allele $\left(\right.$ Pelo $\left.^{\text {flox }}\right)$ could be efficiently switched to Pelo ${ }^{\Delta}$ in cultured Pelo ${ }^{f l o x /}{ }^{-} \mathrm{CreER}^{T}$ fibroblasts in the presence of 0.2 and 1.0 $\mu \mathrm{M}$ hydroxytamoxifen (OHT). $0.6 \times 10^{6}$ cells were plated in $6 \mathrm{~cm}$ dish and after $24 \mathrm{hrs}$ of the culture, OHT was added to the medium. After 3 days of culture in the presence of OHT, DNA and protein were extracted. To determine which concentration of OHT is able to promote the recombination of Pelo ${ }^{\text {flox }}$ to Pelo $^{\Delta}$ allele in culture, we performed 
firstly PCR analysis. Using primers f and g (Fig 3.18) that amplify the deleted fragment, we found that recombination of Pelo ${ }^{\text {flox }}$ allele was more efficiently in culture with $1 \mu \mathrm{M}$ of OHT.

To investigate the frequency of recombination in $\mathrm{Pelo}^{\text {flox/- }} \mathrm{CreER}^{T}$ fibroblasts cultured in the presence of 0.2 and $1 \mu \mathrm{M}$ OHT, Southern blot with EcoRI digested DNA was hybridised with internal probe (Fig 3.18) that recognises Pelo ${ }^{f l o x}$ and Pelo ${ }^{\Delta}$ genomic fragments. As shown in Figure 3.29, the intensity of the 5.0-kb Pelo flox was higher than that of $1.0-\mathrm{kb}$ Pelo ${ }^{\Delta}$ deleted fragment in DNA isolated from cultured Pelo $^{\text {flox/- }} \mathrm{CreER}^{T}$ fibroblasts in the presence of $1 \mu \mathrm{M}$ OHT.

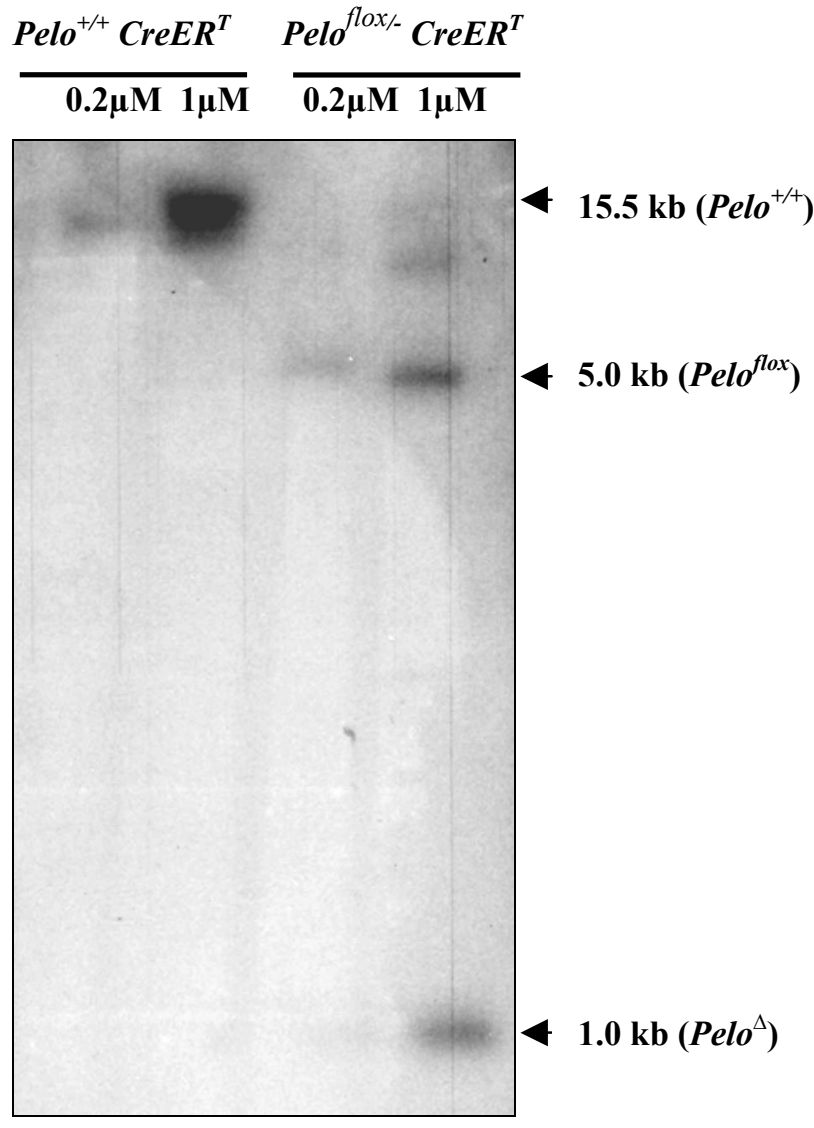

Figure 3.29: Southern blot analysis to evaluate the efficiency of Cre-mediated recombination

Southern blot analysis with EcoRI digested genomic DNA isolated from Pelo $^{\text {flox/ }} \mathrm{CreER}^{T}$ fibroblasts treated with $1 \mu \mathrm{M}$ /day of OHT for 3 consecutive days. Southern blot was hybridised with the internal probe, which recognises the $15.5 \mathrm{~kb}$ fragment of wildtype allele $\left(\right.$ Pelo $\left.^{+}\right), 5.0 \mathrm{~kb}$ fragment of floxed Pelo allele $\left(\right.$ Pelo $\left.^{f l o x}\right)$ and $1.0 \mathrm{~kb}$ fragment of deleted allele $\left(\right.$ Pelo $\left.^{\Delta}\right)$. 


\subsubsection{Expression analysis of Pelota in OHT-treated fibroblasts at protein level}

To confirm the results of Southern blot at protein level, Western blot analysis was performed using total protein extracted from cells which were grown in the presence of 0.2 and $1 \mu \mathrm{M}$ OHT $\left(\right.$ Pelo $^{\text {flox/ }} \mathrm{CreER}^{T}$ and Pelo $^{+/+} \mathrm{CreER}^{T}$ ) and probed with anti-Pelo antibody. The Western blot analysis showed that the expression of Pelo protein was apparently reduced in cells of Pelo ${ }^{f l o x /} \mathrm{CreER}^{T}$ in comparison to $\mathrm{Pelo}^{+/+} \mathrm{CreER}^{T}$ control. This result demonstrates that the Pelo flox allele is not recombined in all Pelo flox/ $\mathrm{CreER}^{T}$ cells and suggest that Cre-mediated deletion occurred in less than $50 \%$ of Pelo flox/CreER ${ }^{T}$ cells.

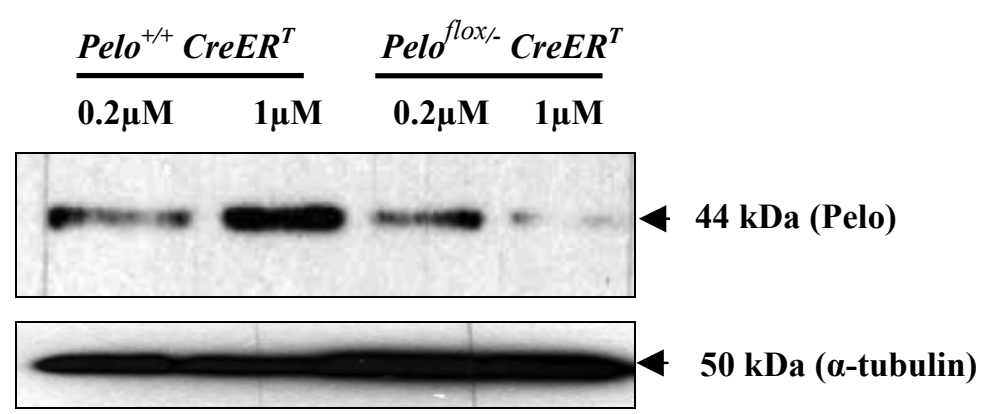

Figure 3.30: Expression of Pelo in OHT-treated $\mathrm{Pelo}^{f l o x /} \mathrm{CreER}^{T}$ and $\mathrm{Pelo}^{+/+} \mathrm{CreER}^{T}$ fibroblasts

Western blot with protein extracting from OHT-treated MEFs was probed with anti-Pelo antibody. Equal protein loading was determined by reprobing the blot with anti- $\alpha$ tubulin antibody.

\subsubsection{Proliferation assay of OHT-treated fibroblasts}

To determine the proliferation of the Pelo ${ }^{\text {flox/- }} \mathrm{CreER}^{T}$ in culture in the presence of $1 \mu \mathrm{M}$ OHT, $0.4 \times 10^{6}$ cells were plated in $6 \mathrm{~cm}$ dish and cultured for 2 days in the presence of 1 $\mu \mathrm{M}$ OHT. Cells were then trypsinised, counted and replated in four $6 \mathrm{~cm}$ dishes and cultured in the presence of $1 \mu \mathrm{M}$ OHT. The number of cells was counted after 2, 4 and 6 days. Results of two independent experiments show that the proliferation of Pelo flox/$\mathrm{CreER}^{T}$ cells in the presence of $1 \mu \mathrm{M}$ OHT is not significantly different from that of control cells (Fig 3.31). This result suggests that either Pelota deficiency does not 
influence cell proliferation or that the $\operatorname{Pelo}^{\Delta /-} \mathrm{CreER}^{T}$ cells might be rapidly diluted in culture by fast growth of the nondeleted cells $\left(\right.$ Pelo $\left.^{\text {flox/- }} \mathrm{CreER}^{T}\right)$.



Figure 3.31: Proliferation assay of OHT-treated fibroblasts

Pelo $^{\text {flox/- }} \mathrm{CreER}^{T}$ and Pelo ${ }^{+/+} \mathrm{CreER}^{T}$ fibroblasts were cultured in the presence of $1 \mu \mathrm{M}$ OHT. Cell number was determined at day 2, 4 and 6. The number of cells was not significantly different between Pelo ${ }^{\Delta /-}$ $C r e E R^{T}$ and control fibroblasts.

\subsubsection{Karyotype analysis of OHT-treated fibroblasts}

Analysis of the conventional Pelota knockout mice revealed the significant increase of aneuploid cells in Pelo-/- embryos at E7.5. To count the number of aneuploid cells, Pelo ${ }^{\text {flox/- }} \mathrm{CreER}^{T}$ MEFs were cultured in the presence of $1 \mu \mathrm{M}$ OHT for 48 hrs and then treated with $100 \mathrm{ng} / \mathrm{ml}$ colcemid for $4 \mathrm{hrs}$ to arrest proliferating cells at metaphase. Cells were fixed and stained with Giemsa as described in methods section (2.2.16.5). Individual metaphase cells were photographed. Photographic files were shuffled and scored blind for the number of chromosomes. The result revealed that 6 out of 21 Pelo $^{+/+} \mathrm{CreER}^{T}$ and 25 out of 40 Pelo $^{\text {flox/- }} \mathrm{CreER}^{T}$ metaphases were aneuploid (Fig 3.32). 


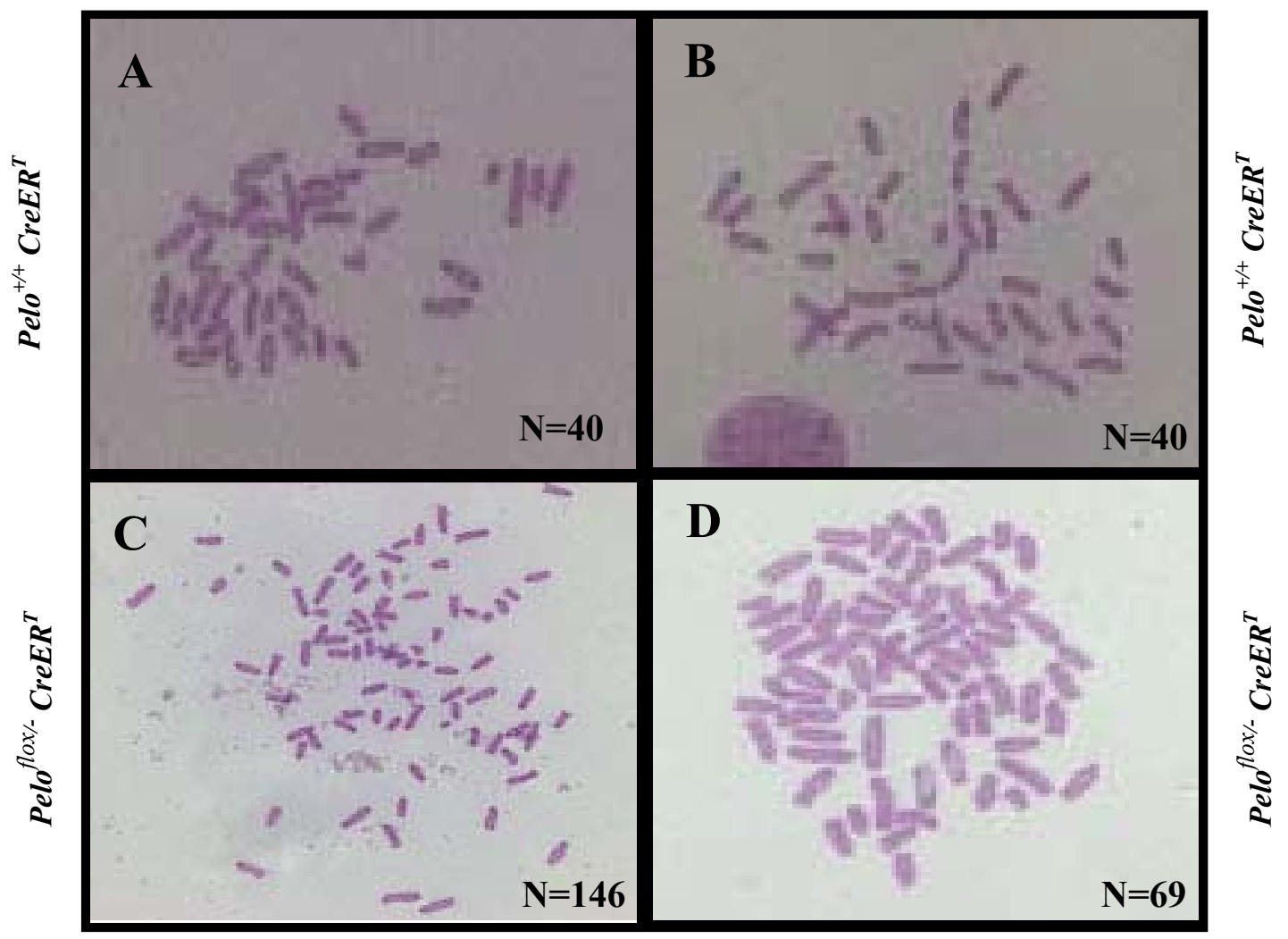

Figure 3.32: Metaphase spreads of OHT-treated fibroblasts

More than $60 \%$ of MEFs cells derived from OHT-treated Pelo flox/ ${ }^{\text {CreER }}{ }^{T}$ (C and D) were found to contain an aneuploid number of chromosomes, whereas $\sim 30 \%$ of control $\mathrm{Pelo}^{+/+} \mathrm{CreER}^{T}$ cells (A and B) were aneuploid. 


\subsection{Pelota transgenic mice}

\subsubsection{Generation of $\boldsymbol{h E F - P e l o}$ transgenic construct and purification}

To study the effect of Pelota overexpression on progression of mitotic and meiotic division, we generated a transgenic construct containing the human Pelota cDNA under the promoter of human elongation factor-1 $1 \alpha(h E F-1 \alpha)$. The 3' untranslated region of the human granulocyte macrophage colony stimulating factor, which contains polyadenylation signal (GM-GSF polyA) was fused downstream of Pelota cDNA. hEF$1 \alpha$ promoter is ubiquitously transactivated and is highly active in testis.

To generate the transgenic construct, a $1.2 \mathrm{~kb}$ fragment of human Pelota cDNA was amplified using specific primers hPelo-F20 and hPelo-R20. The 1.2-kb Pelota cDNA fragment containing $\mathrm{XbaI}$ restriction site was subcloned into pGEMTeasy vector and sequenced. Subsequently, the $1.2 \mathrm{~kb} \mathrm{Xba} I$ fragment was isolated and cloned into $\mathrm{XbaI}$ digested pEF-BOS vector. Positive clones were detected by colony hybridisation. To check right orientation of the insert, test digestion was performed by SstI enzyme. The $h E F-P e l o$ fusion fragment was released from the vector backbone by PvuI and HindIII enzymes, purified and used for microinjection of oocytes. The oocytes were isolated from superovulated $\mathrm{FVB} / \mathrm{N}$ females, injected with the $h E F-P e l o$ transgenic construct and then retransferred into oviducts of pseudopregnant females. Transgenic mice were generated in MPI for experimental Medicine, Göttingen. 


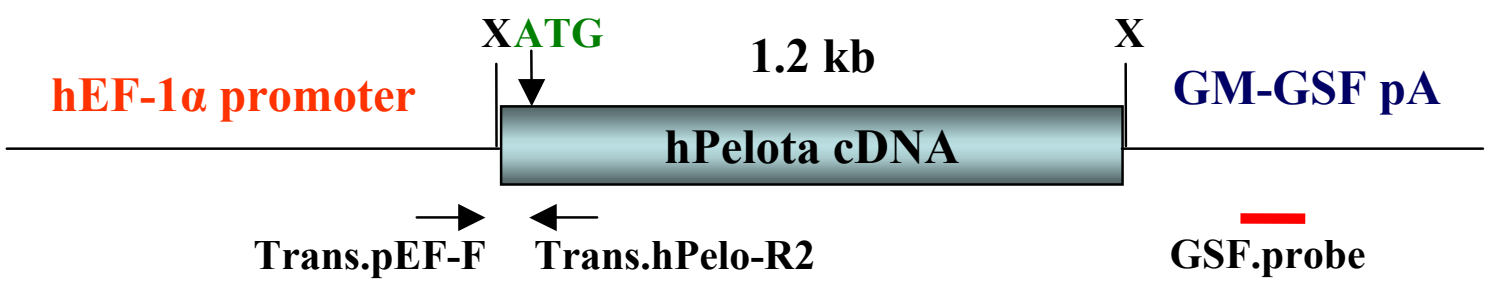

Figure 3.33: Schematic representation of $\mathrm{hEF}$-Pelo transgenic construct

The construct contains the human elongation factor- $1 \alpha$ promoter $(1.2 \mathrm{~kb})$ fused to the human Pelota cDNA $(1.2 \mathrm{~kb})$ and human granulocyte macrophage colony stimulating factor polyadenylation signal (GM-CSF polyA). The primers (arrows) were used for genotyping PCR and GSF-probe was designed for Northern blot hybridisation. X, Xba I cloning site.

\subsubsection{Generation and breeding of transgenic mice}

Transgenic mice harbouring $h E F$-Pelo transgenic allele were identified by PCR with genomic DNA extracted from tail samples of founder mice (Fig 3.34).

Two males out of nine founders were transgenic. From these founders, two transgenic lines were established (Eva \#1 and \#6). Founder mice were crossed with FVB/N females to establish transgenic Eva \#1 and Eva \#6. PCR analysis revealed that the transgenic $h E F-P e l o$ allele is transmitted to offspring of male founders \#1 and \#6.

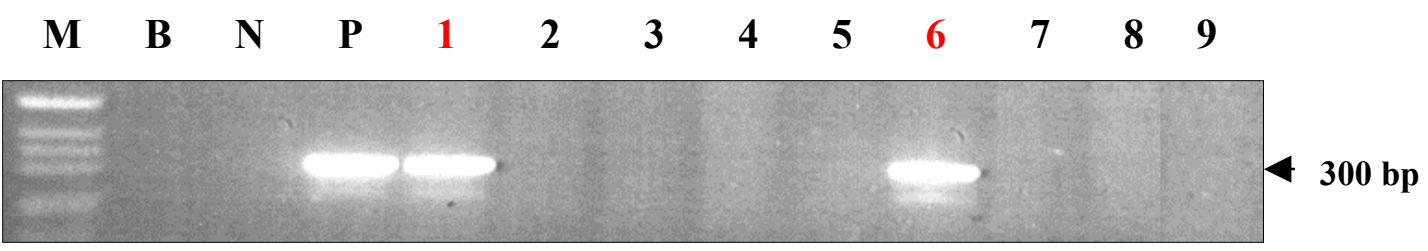

Figure 3.34: Genotyping PCR of hEF-Pelo founder mice.

B, blank control, no DNA template; N, negative control (wildtype DNA); P, positive control (transgenic construct DNA); the primers amplified a 300 bp transgenic allele. Mice No1 and 6 (in red) were found to harbour the transgenic allele. 


\subsubsection{Expression studies of $h E F-P e l o$ transgenic mice}

To examine the expression of $h E F-P e l o$ allele in transgenic mice, total RNA was extracted from testis, kidney and spleen and subjected to Northern blot hybridisation. The hybridisation probe, GSF, was generated by amplification of the GM-GSF polyA cassette of transgenic construct. The probe recognised the fusion transcript only in testis of Eva \#1, whereas no expression of transgenic allele could be detected in kidney and spleen (Fig 3.35A). Expression analysis of Eva \#6 revealed high expression in all studied tissues (Fig 3.35B). To determine the consequence of the Pelota overexpression, transgenic males and females were crossed to wildtype mice. All studied F1 transgenic animals were fertile. Histological analysis of transgenic testis of Eva \#1 displays normal structure of seminiferous tubules (Fig 3.36).
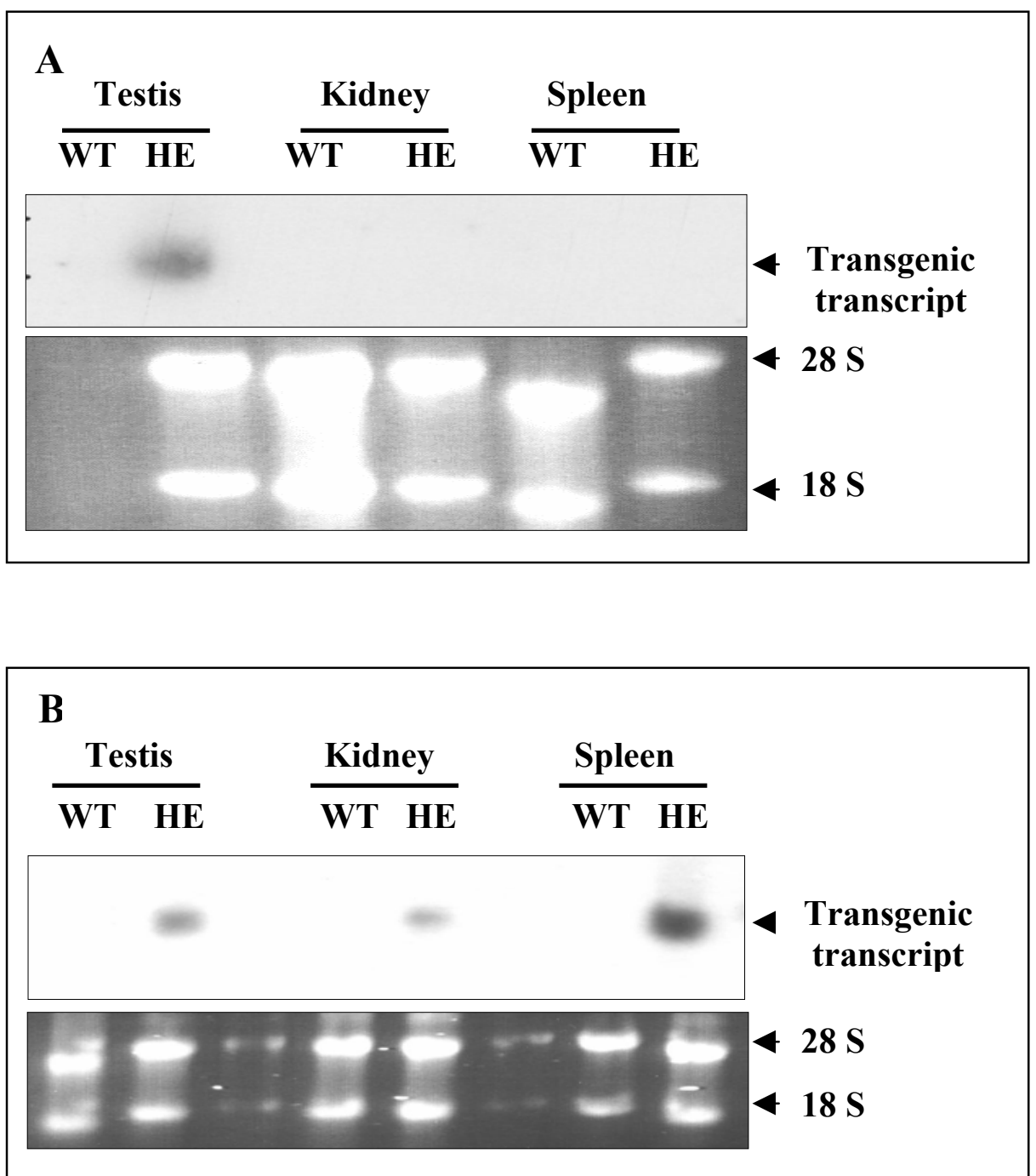
Figure 3.35: Expression analysis by Northern blot

Total RNA was isolated from testis, kidney and spleen of each transgenic line and hybridised with GSF specific probe. A, Eva \#1; B, Eva \#6. WT, wildtype animal; HE, transgenic mice from F1 generation. Integrity of RNA was shown by $28 \mathrm{~S}$ and $18 \mathrm{~S}$ RNA signals on Northern gel picture.

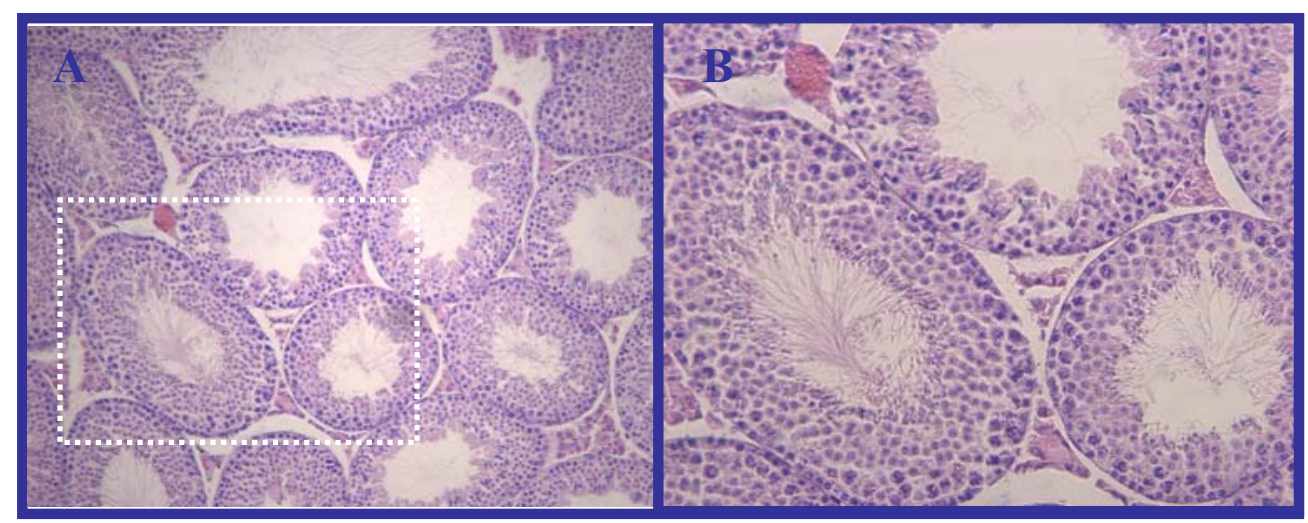

Figure 3.36: Hematoxylin-eosin (H\&E) staining of section of hEF-Pelo testis

Section through testis of Eva \#1 demonstrates normal tubules (A); higher magnification images corresponding to the boxed areas (B).

\subsubsection{Generation of $h U B-P e l o$ transgenic construct and purification}

In addition to hEF-Pelo transgenic mice, we also generated a transgenic construct containing the human Pelota cDNA under the control of the ubiquitously expressed human ubiquitin $(\mathrm{hUbC})$ promoter. The 3' untranslated region of bovine growth hormone, which contains the polyadenylation signal $(B G H \operatorname{poly} A)$ was fused downstream of Pelota cDNA (Fig 3.37).

To generate the transgenic construct, a $1.2 \mathrm{~kb}$ fragment of human Pelota cDNA was amplified using specific primers hPelo-F20 and hPelo-R20. The 1.2-kb Pelota cDNA fragment containing $\mathrm{XbaI}$ restriction site was subcloned into pGEMTeasy vector and sequenced. Subsequently, the $1.2 \mathrm{~kb} E c o R I$ fragment was isolated and cloned into EcoRI digested pUB6/V5-His A vector. Positive clones were detected by colony 
hybridisation. To check right orientation of the insert, test digestion was performed by SstI enzyme. The $h U B$-Pelo fusion fragment was released from the vector backbone by $B g l I I$ and BglI enzymes, purified and used for microinjection of oocytes. The oocytes were isolated from superovulated FVB/N females, injected with the hUB-Pelo transgenic construct and then retransferred into oviducts of pseudopregnant females. Transgenic mice were generated in MPI for experimental Medicine, Göttingen.

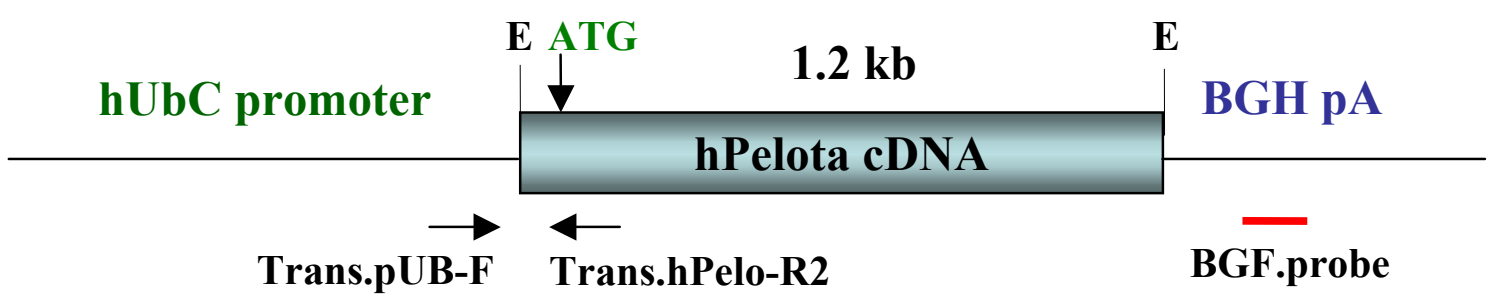

Figure 3.37: Schematic representation of $h U B-P e l o$ transgenic construct

The construct contains the human ubiquitin $C$ promoter $(1.2 \mathrm{~kb})$ fused to the human Pelota cDNA $(1.2 \mathrm{~kb})$ and bovine growth hormone polyadenylation signal (BGH polyA). The primers (arrows) were used for genotyping PCR and BGH-probe was designed for Northern blot hybridisation. E, EcoRI cloning site.

\subsubsection{Generation and breeding of transgenic mice}

Transgenic mice harbouring $h U B$-Pelo transgenic allele were identified by PCR with genomic DNA extracted from tail samples of founder mice (Fig 3.38).

Five males out of fifteen founders were transgenic. From these founders, four transgenic lines were established (Adam \#1, \#9, \#10 and \#13). Founder mice were crossed with $\mathrm{FVB} / \mathrm{N}$ females to establish transgenic Adam \#1, \#9, \#10 and \#13. PCR analysis revealed that the transgenic $h U B$-Pelo allele is transmitted to offspring of male founders $\# 1$, \#9, \#10 and \#13. Transgenic mice harbouring hUB-Pelo transgenic allele were identified by PCR with genomic DNA extracted from tail samples. 


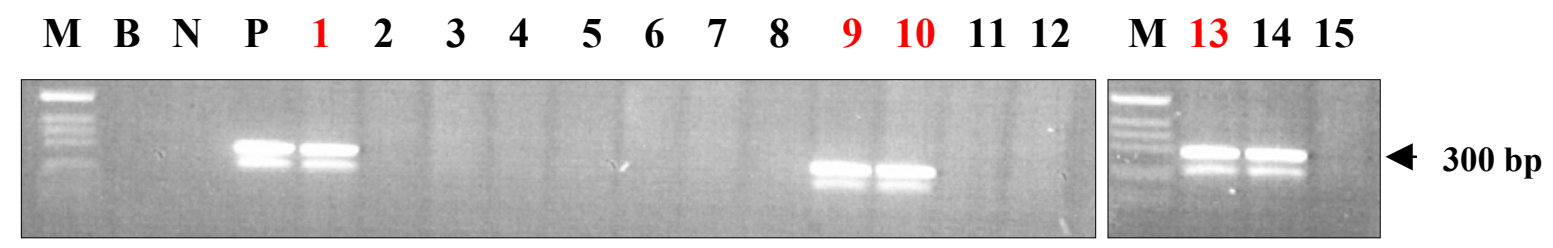

Figure 3.38: Genotyping of $h U B-P e l o$ founder mice.

B, blank control, no DNA template; N, negative control (wildtype DNA); P, positive control (transgenic construct DNA); the primers amplified a 300 bp transgenic allele. Mice No1, 9, 10 and 13 (in red) were found to harbour the transgenic allele.

\subsubsection{Expression studies of $h U B$-Pelo transgenic mice}

To examine the expression of $h U B$-Pelo allele in transgenic mice, total RNA was extracted from testis, kidney and spleen and subjected to Northern blot hybridisation. The hybridisation probe, $B G H$, was generated by amplification of the $B G H$ poly $A$ cassette of transgenic construct. The probe recognised the fusion transcript only in testis of Adam \#1, \#9 and \#10, whereas no expression of transgenic allele could be detected in kidney and spleen (Fig 3.39A; B). In Adam \#13, there was no expression detected in all examined tissues including ovary (Fig 3.39).

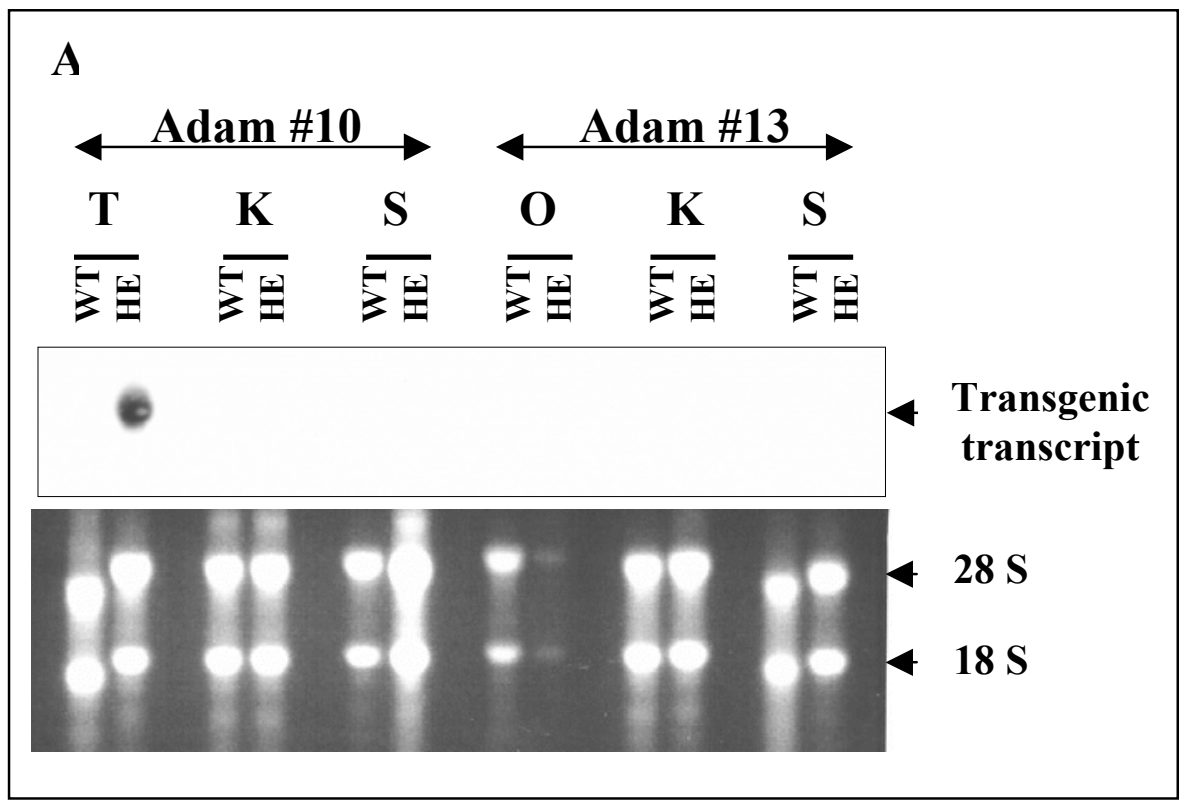




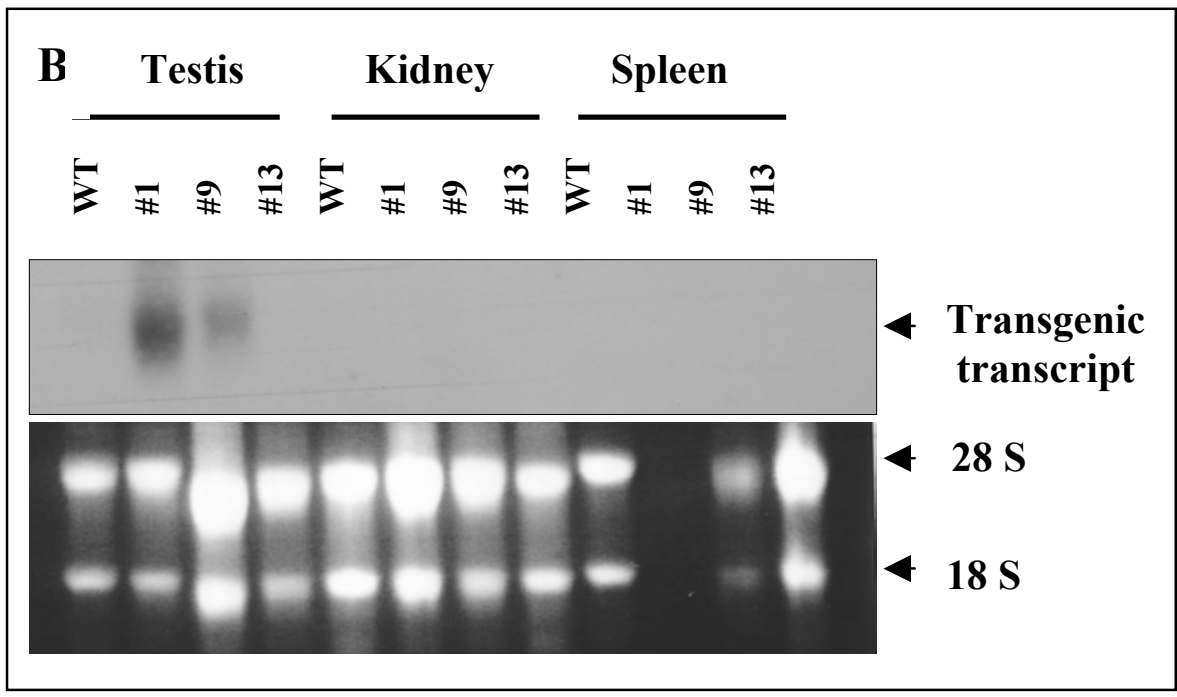

Figure 3.39: Expression analysis by Northern blot

Total RNA was isolated from testis, kidney, and spleen of each transgenic line, also from ovary from Adam \#13, and hybridised with $B G H$ specific probe. A, Adam \#10 and \#13; B, Adam \#1, \#9 and \#13. WT, wildtype animal; HE, transgenic mice from F1 generation. Integrity of RNA was shown by $28 \mathrm{~S}$ and 18S RNA signals on Northern gel picture.

To determine the consequence of the Pelota overexpression, transgenic males and females were crossed to wildtype mice. All studied F1 transgenic animals were fertile. Histological analysis of transgenic testis of Adam \#13 revealed extensive degeneration of germ cells in all seminiferous tubules (Fig 3.40).

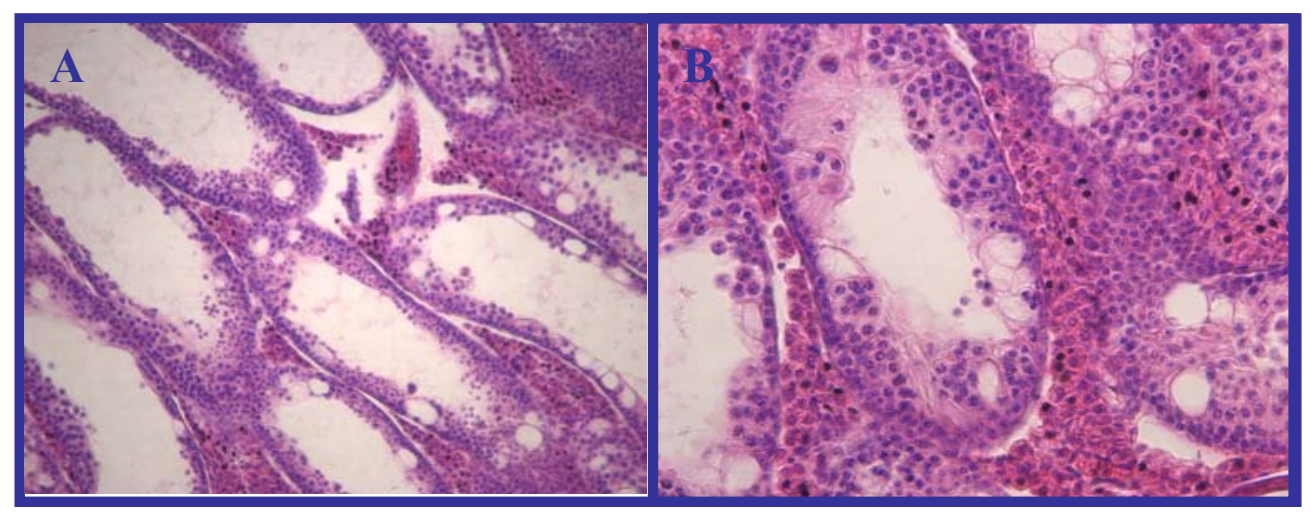

Figure 3.40: Hematoxylin-eosin (H\&E) staining on section of $h U B-P e l o$ testis

Section through testis of Adam \#13 demonstrates drastic reduction of spermatogenic cells in testis of transgenic $h U B$-Pelo mice (A); higher magnification images of same testis sections (B). 


\section{DISCUSSION}

\subsection{Expression pattern and subcellular localisation of Pelota}

The expression pattern of Pelo has been studied in Drosophila, mouse and human at the RNA-level (Eberhart and Wassermann, 1995; Shamsadin et al., 2000; 2002). In mouse and human, the Pelo is ubiquitously expressed in all adult tissues as well as during fetal development. Expression pattern of Pelo in testes at different developmental stages and in testis of $\mathrm{W} / \mathrm{W}^{\mathrm{V}}$ mutant mice that lack germ cells revealed that Pelo is expressed in both somatic and germ cells. Similar expression pattern of Pelo was also found in Drosophila. Analysis of the expression of Pelo gene in Drosophila revealed that Pelo transcript is present in all developmental stages, but is most abundant in $0-2$ hrs old embryos and in adults (Eberhart and Wassermann, 1995). The presence of the Pelo transcript in the germlineless progeny of oskar mutant flies and in iab mutant flies that lack a gonad demonstrated that the Pelo expression is not restricted to the germline.

In this study, we have determined the expression of Pelo in preimplantation stages of mouse. The RT-PCR analysis revealed that the level of Pelo transcript is high in unfertilised oocytes, sharply decreases in 2-, 4-cell stages and then increases again after 8-cell stage (Fig 3.8). This expression pattern demonstrates maternal Pelo-dosage in oocyte which is transferred and used by early embryos during the first rounds of division. The increase of Pelo transcript in morula may be due to the start of expression of zygotic Pelo. To prove the expression pattern of maternal and zygotic Pelo transcript, we have to distinguish between the maternal and paternal transcript by identification of polymorphism in the Pelo transcript. This work is in progress.

In order to study the expression of Pelo at the protein level and to determine the subcellular localisation of Pelo, we have generated polyclonal anti-Pelo antibody that was raised against the Pelo-GST fusion protein. The affinity purified anti-Pelo antibody specifically detects a protein of $44-\mathrm{kDa}$ in Western blot analysis, which is similar in length to the predicted molecular weight of Pelo protein (Fig 3.2). Western blot analyses revealed the presence of the $44-\mathrm{kDa}$ Pelo protein in all studied cell lines and adult mouse tissues (Fig 3.5; Fig 3.6). Like the expression pattern of Pelo transcript, Pelo 
protein was also recognised in testes of mice at different developmental stages and in testis of $\mathrm{W} / \mathrm{W}^{\mathrm{V}}$ mutant mice, which lack germ cells (Fig 3.7A; B).

Immunofluorescence staining of mouse embryonic fibroblasts with the affinity purified anti-Pelo antibody revealed that the Pelo is localised with the cytoskeleton and the perinuclear region (Fig 3.4D). Coimmunofluorescence staining of fibroblasts with antiPelo antibody and phalloidin (Fig 3.4D; E), which specifically binds to stress actin filament, revealed the association of Pelo to the stress actin filament. Localisation of Pelo to cytoskeleton was consistent with the localisation of GFP in transgenic GFP-Pelo fibroblasts (Adham, unpublished data). In Drosophila, Xi et al. (2005) have shown that the subcellular localisation of Pelo is restricted to the cytoplasm. Analysis of amino acid sequences of Drosophila Pelo revealed the presence of a putative nuclear localisation signal sequence (NLS) at its N-terminus (Eberhart and Wassermann, 1995; Nair et al., 2003). The sequence of nuclear localisation signal (NLS) is conserved in mammalian Pelo (Shamsadin et al., 2002). The high fluorescence signal that was found in perinuclear region of fibroblasts using anti-Pelo antibody led us to address the question whether the Pelo is localised to the perinuclear region or in nuclear compartment. Western blot analysis with protein extracted from different cellular fractions of testis revealed the only presence of the $44-\mathrm{kDa}$ Pelo protein in cytoskeleton and membrane fractions (Fig 3.9). The absence of Pelo in nuclear fraction suggests that Pelo is localised in cytoskeleton and perinuclear region. The presence of Pelo in the membrane fraction as shown in Western blot analysis might be due to association of cytoskeleton to the membrane. Further evidence for subcellular localisation of Pelo comes from the identification of the putative interacting partners of Pelo protein (Ebermann 2004; Kirchenmeyer, unpublished results). Most of proteins that specifically interact with Pelo are cytoskeleton-associated proteins.

The role of NLS for Pelo function must be addressed in future experiments. This NLS might be responsible for transport of Pelo and its interacting proteins to the nucleus at specific stage of cell cycle. 


\subsection{Function of mammalian Pelota}

The physiological role of Pelo was determined and analysed by generation of a conventional knockout mouse (Adham et al., 2003). These analyses revealed that Pelo null embryos die after the initiation of gastrulation (E6.5), a particularly active period of cell division characterised by a very short cell cycle (as short as 2 hrs) (Snow, 1977; Hogan et al., 1994). The role of Pelo for control of cellular proliferation was obtained from the results of in vitro culture of blastocysts. While the inner cell mass (ICM) of $\mathrm{Pelo}^{+/+}$and $\mathrm{Pelo}^{+/-}$blastocysts continued to expand throughout the 7-day culture period, $\mathrm{Pelo}^{-/-}$ICM cells failed to proliferate. In contrast, $\mathrm{Pelo}^{-/-}$trophoblast cells continued to grow in size through 7 days of culture. These results demonstrate that the death of Pelo deficient cells is restricted to the rapidly dividing cells of the ICM. The survival of mitotically inactive Pelo ${ }^{-/}$trophoblast cells further argues that Pelo is required selectively in cells undergoing mitosis. To determine the role of Pelo in cell proliferation, we tried to establish $\mathrm{Pelo}^{-/-}$cell line by culture of $\mathrm{Pelo}^{+/-}$ES cells in medium with increasing G418 concentration. Our approach was unsuccessful. Therefore, we started to establish Pelo ${ }^{-/-}$cell line by using the tetracycline inducible siRNA knockdown system and generation of conditional knockout mice using Cre/loxP recombination system, respectively.

\subsection{Knockdown of Pelota using inducible siRNAs system}

RNA interference (RNAi), a well established method for gene knockdown in model organisms (Sharp, 2001), can also be used for gene knockdown in mammalian cells (Elbashir et al., 2001). So-called small interfering RNA (siRNA) has been introduced into mammalian cells by the transient transfection of the synthetic double-stranded RNA. Alternatively, promoters of genes transcribed by RNA polymerase III have been used to drive the expression of hairpin RNAs, which are very similar to siRNAs (Brummelkamp et al., 2002; McManus et al., 2002; Paul et al., 2002; Sui et al., 2002; Yu et al., 2002; Paddison et al., 2002). These siRNA expression vectors have two advantages: they can be stably introduced into cells as selectable plasmids and they are relatively cheap to generate. However, as with conventional knockout strategies, stably 
introduced siRNA vectors cannot be used when the target, as is the case for Pelo, is essential for cellular survival and proliferation. Therefore, the tetracycline inducible siRNA system (van der Wetering et al., 2003) was suggested to be a convenient strategy to establish a stable cell line and conditional induction of Pelo-shRNA (3.2.1). The conditional induction of Pelo-shRNA should allow for time-controlled loss-of-function and the circumventing of the lethal phenotype. Clever's group was the first to report a stable system for inducible expression of shRNAs. In this report, a tet-regulated (tet repressor (TetR)-responsive) variant of the RNA polymerase III-dependent $\mathrm{H} 1$ promoter was used for doxycycline (Dox)-induced shRNA expression and knockdown of $\beta$ catenin in stable transfected colorectal cancer cell clones (van de Wetering et al., 2003). Tetracycline based methods in the mouse with an inducible siRNA expression system have also been used to knockdown several genes (Chen et al., 2003; Czauderna et al., 2003; Dickins et al., 2005). To knockdown the Pelo gene using the Tet-inducible system, we synthesised three different double-stranded oligonucleotides and inserted them in pTER vector. When these oligonucleotides are transcribed, they form a hairpin consisting of a 19-bp stem and a 9-bp loop. Criteria to select the optimal siRNA target sequences were designed according to Reynold et al. (2004). We have expected that one of these transcribed siRNAs is efficient to RNAi-mediated silencing of Pelo. However, RNA analysis of all stable cell lines that transcribed these three different Pelo-siRNAs revealed that the three Pelo-siRNAs failed to RNAi-mediated gene silencing of Pelo. One of the possible reasons for failure of Pelo-siRNA to silence Pelo expression might be due to the designed siRNAs. It is reported that the most effective siRNA can reduce target gene expression by over $90 \%$, but some have minimal or no effect (Bonetta, 2004). Despite the great success of RNAi mediated approaches, the design of highly efficient siRNA still remains a hurdle that has to be overcome (Kurreck, 2006). 


\subsection{Pelota conditional knockout mice}

The role of a particular gene product in vivo is being studied increasingly by either deletion of the gene (gene targeting or knockout) or the gain of its function by transgenic overexpression. Gene targeting is the introduction of a defined modification at a specific location in the genome by homologous recombination. This powerful technique was introduced by Thomas and Capecchi in 1987. Since then, numerous mouse models with defined genomic mutations have been developed.

Although, the conventional gene knockout approach revealed a potential role of Pelo for cell proliferation and/or viability (Adham et al., 2003), the early embryonic lethality prevents us to establish a Pelo-deficient cell line that can be used to study the exact role of Pelo gene. Such a cell line would help us to determine the molecular pathway, in which Pelo is involved. To overcome the early embryonic lethality and to allow us to dissect the role of Pelo in individual cell types (spatial) or during development (temporal), we have used the Cre/loxP system to generate conditional knockout mice. Cre-mediated recombination is achieved by the introduction of the lox $P$ sites within the genomic DNA and expression of the Cre recombinase. Cre is a $38-\mathrm{kDa}$ recombinase that recognises the loxP (locus of crossover P1) site, a 34-bp sequence consisting of two 13-bp inverted repeats, separated by an 8-bp directional spacer. Intramolecular recombination results in either excision of intervening DNA (if the two loxP sites are tandem repeats) or DNA inversion (if the sites are positioned in opposite orientations).

Using homologous recombination, we have established a mouse line in which the coding region of the Pelo gene is flanked by two loxP sites (Fig 3.18). We successfully generated several high chimeric male mice. These chimeric mice were bred to C57BL/C6 females to generate heterozygous Pelo flox/+ mice in F1 generation. The $\mathrm{Pelo}^{f l o x /+}$ mice were then intercrossed with $\mathrm{Pelo}^{\text {flox/+ }}$ or with Pelo ${ }^{+/-}$mice to generate

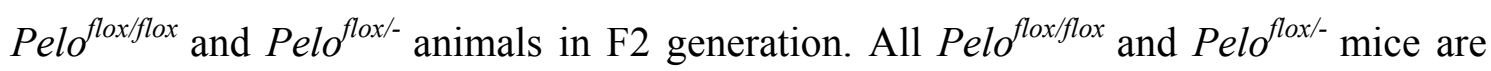
viable and fertile indicating that the insertion of loxP and neomycin cassette $(\mathrm{Neo})$ in intron 1 and 3' flanking region of the gene did not disrupt the Pelo ${ }^{\text {flox }}$ allele.

To determine whether the floxed Pelo allele can be deleted in vivo, Pelo floxed mice were mated with EIIaCre transgenic mice, in which the Cre gene is under the control of the adenovirus EIIa promoter. The transactivation of the EIIa promoter is restricted to oocytes and preimplantation stages of the embryo (Lakso et al., 1996). Southern blot 
analyses showed that the efficiency of Cre-mediated recombination in F1 generation was variable and resulted in different degree of mosaicism (Fig 3.23A), whereas EIIaCre completely recombined floxed allele in F2 generation (Fig 3.23B). The complete excision of the floxed Pelo $\left(\mathrm{Pelo}^{\Delta}\right)$ allele in Pelo ${ }^{\text {flox/+ }}$ EIIaCre double transgenic mice clearly showed that the generated Pelo flox allele can successfully recombine with Cre recombinase in an in vivo system. A similar mechanism of Cre expression during preimplantation stages for partial excision was postulated for EIIaCre mediated recombination (Holzenberger et al., 2000). As expected, we did not find Pelo ${ }^{\Delta /-}$ EIIaCre mice in F2 generation suggesting that these mice died during embryonic development like the Pelo $^{-/-}$mice.

Subsequently, to achieve temporal inactivation of floxed Pelo allele in vivo and to study the distinct function of Pelo gene, Cre-ER ${ }^{T}$ fusion allele was introduced in the genome of Pelo flox/- mice. TAM-treated Pelo ${ }^{\Delta /-} \mathrm{CreER}^{T}$ mice were subfertile. In contrast, all treated control Pelo ${ }^{+/+} \mathrm{CreER}^{T}$ were fertile. Histological analysis of testes from TAMtreated Pelo flox/ $\mathrm{CreER}^{T}$ and $\mathrm{Pelo}^{+/+} \mathrm{CreER}^{T}$ control animals revealed extensive degeneration of a large fraction of seminiferous tubules in mutant mice (Fig 3.25). However, the observed germ cell depletion varied between TAM-treated Pelo ${ }^{\text {flox- }}$ $\mathrm{CreER}^{T}$ mice. Western blot analysis revealed the significant decrease of protein level of Pelo in testis of TAM-treated Pelo flox/- $\mathrm{CreER}^{T}$ mice with severe germ cell depletion (Fig 3.28), while mice with less germ cell depletion did not show a significant downregulation of Pelo protein in testis. These results demonstrate that the inducible deletion of floxed Pelo allele by $C r e E R^{T}$ did not occur in all testicular cells resulting in mosaic of Pelo flox/- and Pelo ${ }^{\Delta /-}$ cells. Southern blot analysis of different tissues of TAMtreated Pelo ${ }^{\text {flox/- }} \mathrm{CreER}^{T}$ mice revealed that the efficiency of Pelo ${ }^{\text {flox }}$ deletion was high in spleen $(<50 \%)$ and less efficient in kidney and tail $(\sim 25 \%)$. Such variability in the efficient deletion of floxed allele in different tissues was also described in several published reports (Vooijs et al., 2001; Alonzi et al., 2001). The reduced efficiency of deletion by $C r e E R^{T}$ can be explained by a lower or less uniform expression of R26$\mathrm{CreER}^{\mathrm{T}}$ or less efficient activation of $\mathrm{CreER}^{T}$ due to a lower local concentration of OHT (Robinson et al., 1991). Nevertheless, the increase of the germ cell depletion in testes of TAM-treated mice suggests that Pelo is essential for spermatogenesis. 


\subsection{The effect of Pelota deficiency on cell proliferation}

To determine the consequence of Pelo deficiency on cell proliferation, mouse embryonic fibroblasts (MEFs) were isolated from Pelo $^{f l o x /} \mathrm{CreER}^{T}$ and $\mathrm{Pelo}^{+/+} \mathrm{CreER}^{T}$ at embryonic day 13.5. Primary MEFs were cultured for two days in the presence of 100 $\mathrm{nM}$ and $1 \mu \mathrm{M}$ of 4-hydrotamoxifen (OHT), respectively, and the proliferation rate of both cell lines was then determined. These experiments did not show significant differences in the proliferation rate between Pelo $^{\text {flox/- }} \mathrm{CreER}^{T}$ and control cells. We could not show differences between both cell lines in cell cycle profile, which is determined by flow cytometry (data not shown). Recombination of a floxed Pelo allele was determined after culturing cells with $100 \mathrm{nM}$ and $1 \mu \mathrm{M}$ OHT for 4 consecutive days. No Cre-mediated recombination of the floxed Pelo allele has occurred in the presence of $0.1 \mu \mathrm{M}$ OHT, while the recombination of Pelo $^{\text {flox }}$ allele to Pelo $^{\Delta}$ allele was more efficient $(50 \%)$ in culture with $1 \mu \mathrm{M}$ OHT. These results suggest that either Pelodeficiency does not influence cell proliferation or that the $P e l{ }^{\Delta /-} \mathrm{CreER}^{T}$ cells might be rapidly diluted in culture by fast growth of the nonrecombined cells (Pelo ${ }^{\text {flox/- }} \mathrm{CreER}^{T}$ ). Other published reports have shown that after growth of Brca $2^{\text {floxflox }}$ fibroblasts in the presence of $1 \mu \mathrm{M}$ OHT for $24 \mathrm{hrs}$ and a subsequent period of $24 \mathrm{hrs}$ to allow for clearance of the OHT-bound CreERT protein, $\sim 90 \%$ of the MEFs had undergone recombination of a floxed target gene (Vooijs et al., 2001). Therefore, it is recommended to determine the OHT concentration and OHT exposure times, which result in high recombination efficiency of floxed allele and without toxic effect on cells (Loonstra et al., 2001). Furthermore, a marked difference in recombination efficiency between different primary cell types was found. For example, culture of primary R26CreER ${ }^{\mathrm{T}}$ keratinocytes at low dose of OHT (100 nM) is already sufficient for $\geq 90 \%$ recombination of the floxed Brca $2^{\text {flox }}$ allele within $48 \mathrm{hrs}$ (Vooijs et al., 2001).

Analysis of the conventional Pelota knockout mice revealed a significant increase of aneuploid cells in Pelo ${ }^{-/}$embryos at E7.5. Karyotype analysis of OHT-treated MEFs revealed an increased rate of aneuploid cells in analysed metaphases of $\mathrm{Pelo}^{\text {flox/- }} \mathrm{CreER}^{T}$ MEFs, while the rate of aneuploid cells was $30 \%$ in control metaphases $\left(\right.$ Pelo $\left.^{+/+} \mathrm{CreER}^{T}\right)$. Like the observed results in Pelo $^{-/-}$embryos, most of aneuploid Pelo ${ }^{\text {flox/- }} \mathrm{CreER}^{T}$ cells were polyploid. The polyploidy can arise by exit of a cell from mitosis following failures of spindle assembly, chromosome segregation or cytokinesis 
(Andreassen et al., 1996). Actin assembly is required for cytokinesis (Aubin et al., 1981; Martineau et al., 1995). Deficiency of Pelo, which we found to be associated with stress actin, may affect of the actin assembly during the cytokinesis. The resulting tetraploid cells become arrested in the cell cycle G1 by activation of the tetraploidy checkpoint. Inactivation of this checkpoint would uniformly result in aneuploidisation following passage of tetraploid cells through the next cell cycle and consequent induction of multipole spindles. Polyploid embryos of survivin-deficient mice fail to survive past E4.5 (Cutts et al., 1999; Uren et al., 2000). Studies of human embryos revealed that $70 \%$ of all preimplantation embryos exhibit a mosaic aneuploid karyotype (Sandalinas et al., 2001).

Three different types of mosaicism have been described within preimplantation embryos diploid polyploid, mitotic non-disjunction and chaotic aneuploidy (Delhanty et al., 1997). It has been suggested that $90 \%$ of all human mosaic aneuploid embryos are lost during the first trimester (Munne et al., 2004). In mouse, the mosaic aneuploid embryos can develop and implant into the female uterine tissue and initiate the gastrulation process (E6.5), but then quickly degrade and succumb by E8.0 (Lightfoot et al., 2006). The time point of death of mosaic aneuploid embryos coincides with the death of Pelo ${ }^{-/}$embryos, which display a mosaic aneuploidy (Adham et al., 2003).

\subsection{Drosophila Pelota controls self renewal of germline stem cells}

Recently, an unexpected role for Pelota in control of self-renewal of germline stem cells (GSC) has been reported in Drosophila (Xi et al., 2005). In the Drosophila ovary, germline stem cell (GSC) self-renewal is controlled by both extrinsic and intrinsic factors. In the Drosophila ovary, GSCs reside in a structure called the germarium, which is at the anterior end of an ovariole (Lin, 2002). At the anterior tip of the germarium, three types of somatic cells, cap cells and inner sheath cells, constitute a niche that supports two or three GSCs. One GSC divides to generate two daughter cells: the daughter cell maintaining contact with the cap cells renews itself as a stem cell, while the daughter cell moving away from the cap cells differentiates into a cystoblast. The cystoblast divides four times with incomplete cytokinesis to form a 16-cell cyst, in which one cell becomes an oocyte and the rest becomes nurse cells in Figure 4.1 (Xi et al., 2005). 


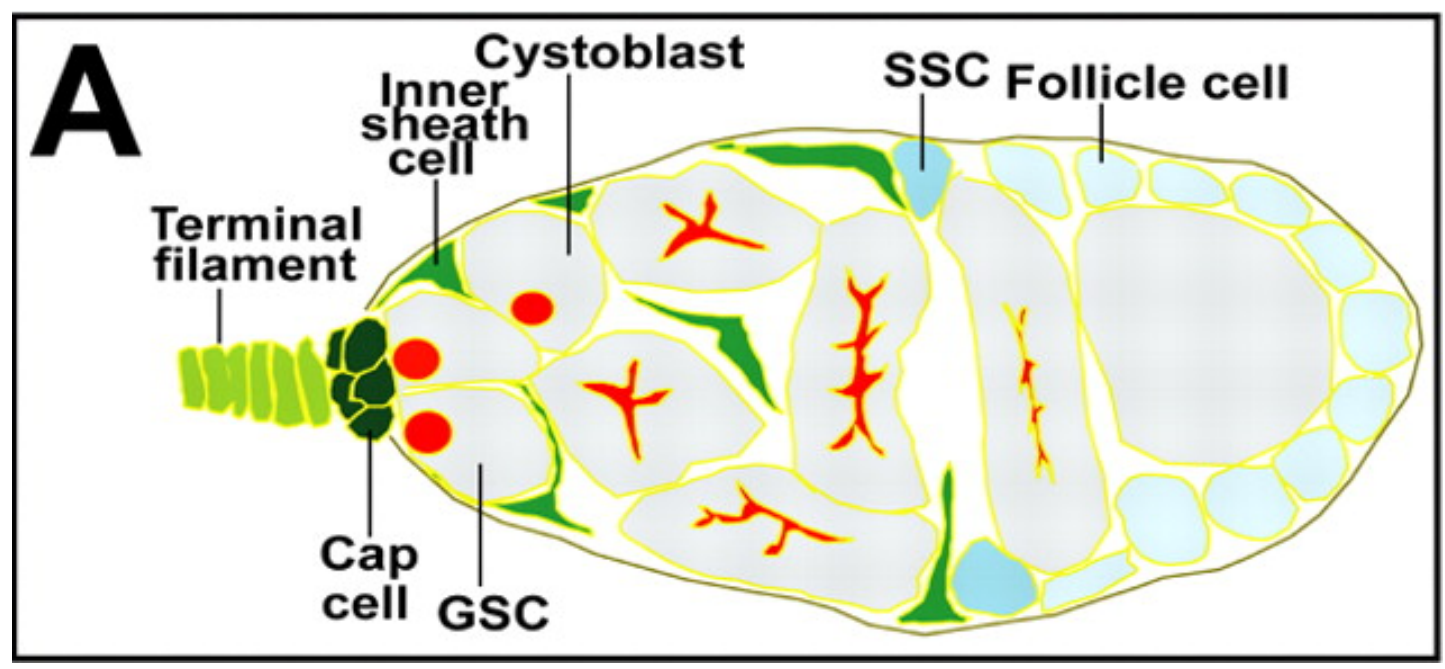

Figure 4.1 A schematic diagram of the germarium. Red circles indicate spectrosomes (GSCs and cystoblasts) and branched red structures indicate fusomes (germ cell cysts) (Xi et al., 2005).

Bone marrow protein (BMP)/dpp produced from cap cells function as short-range signals that directly repress the transcription of differentiation-promoting gene bam in GSCs to maintain their self-renewal, and also allow cystoblasts lying one cell diameter away to differentiation (Chen and McKearin, 2003a; Song et al., 2004). Overexpression of $b m p / d p p$ in the inner sheath cells of germarium of transgenic flies leads to repression of the bam expression in all GSCs daughter cells. The maintenance of self-renewal and blocking of germ cell differentiation in all GSCs daughter cells results in the formation of GSC-like tumors and consequently in female sterility (Song et al., 2004). In genetic screen to identify genes which are potentially involved in Bmp signalling in GSCs, Xi et al. (2005) has identified Pelo as a dominant suppressor of the bmp/dpp overexpressioninduced GSC tumor phenotype. Mutation of Pelo gene in transgenic ovary, which overexpresses $b m p / d p p$ signals, induces the expression of differentiation-promoting genes in GSCs and thereby rescues Bmp/dpp overexpression-induced female infertility. These results indicate that Pelo is required intrinsically for controlling GSC selfrenewal by repression of differentiation-promoting genes. These results also support that expression of Pelo is regulated by Bmp signalling. Furthermore, this report found that Pelo downregulates the expression of Dad gene, which is one of Bmp-target genes in GSC. The Dad is the orthologous gene of mammalian Smad gene. The identified role of Pelo for repressing differentiation pathways in germline stem cells might explain the 
proliferation arrest of embryonic stem cells in murine Pelo $^{-/-}$blastocysts. The absence of Pelo in mammalian ES cells may result to induce the expression of differentiationpromoting genes that block the self-renewal of embryonic stem cells during gastrulation.

To identify the role of mammalian Pelo in control of self-renewal and to determine its role in the Bmp-signal pathway, we have to establish a Pelo ${ }^{\text {flox/- }} \mathrm{CreER}^{T} \mathrm{ES}$-cell line and Pelo $^{\text {flox/- }} \mathrm{CreER}^{T}$ spermatogonia stem cells, and then to determine proliferation and pluripotency of these cell lines after deletion of Pelo floxed allele $\left(\right.$ Pelo $\left.^{\Delta-} \mathrm{CreER}^{T}\right)$. Analysis of expression and activity of different members of Bmp-pathway in the Pelo ${ }^{\Delta /-}$ $\mathrm{CreER}^{T}$ stem cells will give us information about the role of Pelo in the Bmp signalling. In this study, we have determined the consequence of Pelo deletion in adult mice and found that spermatogenesis is affected. To determine the role of Pelo in vivo on the selfrenewal of fetal and adult stem cells, we have to treat the Pelo ${ }^{\text {flox/- }} \mathrm{CreER}^{T}$ mice with Tamoxifen at different stages of pre and postnatal development.

\subsection{The effect of overexpression of Pelota gene}

In the present study, the effect of Pelo overexpression was investigated by generation of transgenic mice (hEF-Pelo) containing the human Pelota cDNA under the promoter of human elongation factor-1 $\alpha(h E F-1 \alpha)$. The expression analysis revealed a high expression of the transgenic allele in testis of one transgenic line (Eva \#1), but not in other tissues. In the other transgenic line (Eva \#6), expression of the transgenic allele was detectable in all tissues. Histological analysis of testis of transgenic line Eva \#1 (F1) displays normal structure of seminiferous tubules (Fig 3.36). Despite high levels of exogenous Pelo expression in multiple tissues, the male Eva \#6 mice displayed normal development, indicating that overexpression of Pelo does not affect embryogenesis and early development. The $h E F-1 \alpha$ gene is normally expressed in most tissues (Uetsuki et al., 1989; Mizushima et al., 1990) and the regulatory region of the gene which was used for our transgene construct is known to direct strong expression in various cultured cells (Mizushima et al., 1990). The truncated regulatory region apparently activates transcription preferentially in germ cells in a physiological context. Nevertheless, the parallel increase of the endogenous Pelo in transgenic mice raises the possibility that the exogenous Pelo protein is not active in mice and could antagonise the effect of the 
endogenous protein. Thus, it might be the lack rather than the excess of Pelo expression that is responsible for the interruption of spermatogenesis.

In our study, we have also generated a second transgenic mouse (hUB-Pelo), in which the human Pelota cDNA is under the control of the ubiquitously expressed human ubiquitin $C(h U b C)$ promoter. The human ubiquitin $C$ promoter was chosen because it provides a strong cellular promoter capable of driving expression of our transgene in vivo, as previously described (Schaefer et al., 2001). We have detected the fusion transcript only in testis of three transgenic lines (Adam \#1, \#9 and \#10), whereas no expression of transgenic allele could be detected in kidney and spleen (Fig 3.39) by Northern blot analyses. Interestingly, in transgenic line (Adam \#13) the expression of the transgenic allele was not detected in all examined tissues. However, histological analysis of transgenic testis of Adam \#13 revealed depletion of germ cells in all seminiferous tubules (Fig 3.40). There are two explanations for this phenotype. Firstly, the overexpression of Pelo in transgenic testis leads to the depletion of Pelooverexpressing germ cells. Therefore, we were not able to detect the expression of the transgenic allele in the line Adam \#13 by Northern blot analyses. However, the overexpression of the transgenic allele does not affect the spermatogenesis in other transgenic line (Eva \#1) which does not support the hypothesis that overexpression of Pelo disrupts spermatogenesis. Therefore, germ cell depletion shown in testis of transgenic line Adam \#13 may be due to the insertion of the transgenic allele in a genomic locus, which is involved in the germ cell development. Further analyses of transgenic Pelo mice will provide us with information about the effect Pelo overexpression in germ cell development. 


\section{SUMMARY}

The aims of this study were to determine expression pattern and subcellular localisation of Pelo protein, and generation and analysis of Pelo conditional knockout mice.

In order to study the expression of Pelo at the protein level, we have generated polyclonal anti-Pelo antibody that was raised against the Pelo-GST fusion protein. The affinity purified anti-Pelo antibody specifically detects a protein of 44-kDa in Western blot analysis, which is similar in length to the predicted molecular weight of Pelo protein. Western blot analyses revealed the presence of the $44-\mathrm{kDa}$ Pelo protein in all studied cell lines and adult mouse tissues.

Immunofluorescence staining of mouse embryonic fibroblasts with the affinity purified anti-Pelo antibody revealed that the Pelo is localised to the cytoskeleton and perinuclear region. Coimmunofluorescence staining of fibroblasts with anti-Pelo antibody and phalloidin, which specifically binds to stress actin filament, revealed the association of Pelo to the stress actin filament. Localisation of Pelo to cytoskeleton was consistent with the localisation of GFP in transgenic GFP-Pelo fibroblasts. Western blot analysis with protein extracted from different cellular fractions of testis revealed the only presence of the 44-kDa Pelo protein in cytoskeleton and membrane fractions. The absence of Pelo in nuclear fraction suggests that Pelo is localised in cytoskeleton and perinuclear region.

To investigate the consequence of Pelo knockdown on cell proliferation, Tet inducible siRNAs system was performed. Three siRNA sequences targeting different regions within the Pelo mRNA were tested for their efficiency to specifically knockdown Pelo in cell culture. The Western blot and Northern blot analyses revealed the failure of the three Pelo-siRNAs to RNAi-mediated gene silencing of Pelo.

To circumvent early embryonic lethality of conventional Pelo null mice being able to investigate the in vivo roles of murine Pelo gene during later stages of embryonic development and adult, we generated Pelo conditional knockout mice using inducible Cre/loxP recombination system. We successfully generated several high chimeric male mice, which transmitted the Pelo ${ }^{f l o x}$ allele to their offspring. The Peloflox/t mice were then intercrossed with Pelo flox/+ or with $\mathrm{Pelo}^{+/-}$mice to generate Pelo ${ }^{\text {flox/flox }}$ and Pelo flox/animals in F2 generation. All Pelo floxflox and Pelo flox/- mice are viable and fertile 
indicating that the insertion of loxP and neomycin cassette (Neo) in intron 1 and $3^{\text {' }}$ flanking region of the gene did not disrupt the Pelo allele.

To determine whether the floxed Pelo allele can be deleted in vivo, Pelo floxed mice were mated with EIIaCre transgenic mice in which the adenovirus EIIa promoter directed the action of Cre recombinase gene to the single-cell zygote. The complete excision of the floxed Pelo $\left(\right.$ Pelo $\left.^{\text {flox }}\right)$ allele in Pelo ${ }^{\text {flox/+ }}$ EIIaCre double transgenic mice clearly showed that the generated Peloflox allele can successfully recombine with Cre recombinase in vivo system. As expected, we did not find Pelo ${ }^{\Delta-}$ EIIaCre mice in F2 generation suggesting that these mice died during embryonic development like the conventional Pelo deficient mice.

To achieve temporal inactivation of floxed Pelo allele in vivo and to study distinct function of Pelo gene, Cre-ER fusion allele was introduced in the genome of Pelo ${ }^{\text {flox- }}$ mice. Tamoxifen (TAM)-treated Pelo ${ }^{f l o x /}{ }^{-} \mathrm{CreER}^{T}$ mice are subfertile. Histological analysis of testes from TAM-treated $P e l o^{f l o x /}{ }^{-} \mathrm{CreER}^{T}$ mice revealed severe germ cell depletion. The increase of the germ cell depletion in testes of TAM-treated mice suggests that Pelo is essential for spermatogenesis.

Moreover, Southern blot analysis of different tissues of TAM-treated Pelo flox/- $\mathrm{CreER}^{T}$ mice revealed that the efficiency of Pelo ${ }^{f l o x}$ deletion was high in spleen $(<50 \%)$ and less efficient in kidney and tail $(\sim 25 \%)$. Western blot analysis revealed that the significant decrease of protein level of Pelo in testes of TAM-treated Pelo flox/- $C r e E R^{T}$ mice with severe germ cell depletion, while that with less germ cell depletion did not show a significant downregulation of the Pelo in testis. These results revealed the inducible deletion of floxed Pelo allele by $\mathrm{CreER}^{T}$ did not occur in all testicular cells.

To study the consequences of Pelo deficiency on cell proliferation, mouse embryonic fibroblasts (MEFs) were isolated from Pelo flox/- $\mathrm{CreER}^{T}$ and $\mathrm{Pelo}^{+/+} \mathrm{CreER}^{T}$ embryos. Southern blot anaylsis showed that the Cre-mediated recombination occurred partially in OHT-treated fibroblasts of Pelo ${ }^{f l o x /} \mathrm{CreER}^{T}$ mice. The proliferation assay of OHTtreated Pelo ${ }^{\text {flox/- }} \mathrm{CreER}^{T}$ fibroblasts suggests that either Pelo deficiency does not influence cell proliferation or that the $\mathrm{Pelo}^{\Delta /-} \mathrm{CreER}^{T}$ cells might be rapidly diluted in culture by fast growth of the nondeleted cells (Pelo ${ }^{f l o x /} \mathrm{CreER}^{T}$ ). Karyotype analysis of OHT-treated MEFs revealed an increased rate of aneuploid cells in analysed metaphases of Pelo flox/- $\mathrm{CreER}^{T}$ MEFs.

To investigate the effect of Pelo overexpression, we generated two transgenic constructs and mice. In the first transgenic construct, the human Pelota cDNA is under the control 
of human elongation factor-1 $\alpha$ promoter ( $h E F-P e l o)$. Expression analysis revealed a high expression of transgenic allele only in testis of one transgenic line. In the other transgenic line, expression of transgenic allele was detectable in all studied tissues.

The second transgenic mice ( $h U B-P e l o$ ) contain the human Pelota cDNA under the control of human ubiquitin $C(h U b C)$ promoter. The expression analysis revealed that the expression of the transgenic transcript is restricted in testis of three generated lines. 


\section{REFERENCES}

Adham IM, Sallam MA, Steding G, Korabiowska M, Brinck U, Hoyer-Fender S, Oh C, Engel W. 2003. Disruption of the pelota gene causes early embryonic lethality and defects in cell cycle progression. Mol Cell Biol. 23:1470-6.

Alonzi T, Maritano D, Gorgoni B, Rizzuto G, Libert C, Poli V. 2001. Essential role of STAT3 in the control of the acute-phase response as revealed by inducible gene inactivation in the liver. Mol Cell Biol. 21:2967.

Andreassen PR, Martineau SN, Margolis RL. 1996. Chemical induction of mitotic checkpoint override in mammalian cells results in aneuploidy following a transient tetraploid state. Mutat Res. 372:181-94.

Arin MJ, Longley MA, Wang XJ, Roop DR. 2001. Focal activation of a mutant allele defines the role of stem cells in mosaic skin disorders. J Cell Biol. 152:645-649.

Aubin JE, Osborn M, Weber K. 1981. Inhibition of cytokinesis and altered contractile ring morphology induced by cytochalasins in synchronized PtK2 cells. Exp Cell Res. 136:63-79.

Ausubel FM, Brent R, Kingston RE, Moore DD, Seidman JG, Smith JA, Struhl K. 1994. Current Protocols in Molecular Biology, (John Wiley \& Sons Inc., USA).

Bennett WI, Gall AM, Southard JL, Sidman RL. 1971. Abnormal spermiogenesis in quaking, a myelin-deficient mutant mouse. Biol Reprod. 5:30-58.

Berado MD, O'Connell P, Allred DC. 1996. Biological characteristics of premalignant and preinvasive breast disease. Hormone-Dependent Cancer 1-23.

Birnboim HC, Doly J. 1979. A rapid alkaline extraction procedure for screening recombinant plasmid DNA. Nucleic Acids Res. 7:1513-23.

Bonetta L. 2004. RNAi: Silencing never sounded better. Nature Methods. 1:79-86.

Bradford MM. 1976. A rapid and sensitive method for the quantitation of microgram quantities of protein utilizing the principle of protein-dye binding. Anal Biochem. 7:24854.

Branda CS, Dymecki SM. 2004. Talking about a revolution: The impact of site-specific recombinases on genetic analyses in mice. Dev Cell. 6:7-28.

Bridge AJ, Pebernard S, Ducraux A, Nicoulaz A-L, Iggo R. 2003. Induction of an interferon response by RNAi vectors in mammalian cells. Nature Genetics. 34:263-264. 
Brocard J, Warot X, Wendling O, Messaddeq N, Vonesch JL, Chambon P, Metzger D. 1997. Spatio-temporally controlled site-specific somatic mutagenesis in the mouse. Proc Natl Acad Sci U S A. 23:14559-63.

Brummelkamp TR, Bernards R, Agami R. 2002. A system for stable expression of short interfering RNAs in mammalian cells. Science. 296:550-3.

Bult CJ, White O, Olsen GJ, Zhou L, Fleischmann RD, Sutton GG, Blake JA, FitzGerald LM, Clayton RA, Gocayne JD, Kerlavage AR, Dougherty BA, Tomb JF, Adams MD, Reich CI, Overbeek R, Kirkness EF, Weinstock KG, Merrick JM, Glodek A, Scott JL, Geoghagen NS, Venter JC. 1996. Complete genome sequence of the methanogenic archaeon, Methanococcus jannaschii. Science. 23:1058-73.

Bunting M, Bernstein KE, Greer JM, Capecchi MR, Thomas KR. 1999. Targeting genes for self-excision in the germ line. Genes Dev. 13:1524-8.

Busch SJ, Sassone-Corsi P. 1990. Dimers, leucine zippers and DNA-binding domains. Trends Genet. 6:36-40.

Carr-Schmid A, Pfund C, Craig EA, Kinzy TG. 2002. Novel G-protein complex whose requirement is linked to the translational status of the cell. Mol Cell Biol. 22:2564-2574.

Castrillon DH, Gonczy P, Alexander S, Rawson R, Eberhart CG, Viswanathan S, DiNardo S, Wasserman SA. 1993. Toward a molecular genetic analysis of spermatogenesis in Drosophila melanogaster: characterization of male-sterile mutants generated by single P element mutagenesis. Genetics. 135:489-505.

Gershoni JM, Palade GE. 1982. Electrophoretic transfer of proteins from sodium dodecyl sulfate-polyacrylamide gels to a positively charged membrane filter. Anal Biochem. 124:396-405.

Chen D, McKearin D. 2003. Dpp signaling silences bam transcription directly to establish asymmetric divisions of germline stem cells. Curr Biol. 13:1786-1791.

Chen Y, Stamatoyannopoulos G, Song CZ. 2003. Down-regulation of CXCR4 by inducible small interfering RNA inhibits breast cancer cell invasion in vitro. Cancer Res. 63:4801-4.

Chien A, Edgar DB, Trela JM. 1976. Deoxyribonucleic acid polymerase from the extreme thermophile Thermus aquaticus. J Bacteriol. 127:1550-7.

Clark JM. 1988. Novel non-templated nucleotide addition reactions catalyzed by procaryotic and eucaryotic DNA polymerases. Nucleic Acids Res. 16:9677-86.

Cogoni C, Macino G. 2000. Post-transcriptional gene silencing across kingdoms. Curr Opin Genet Dev. 10:638-43. 
Cutts SM, Fowler KJ, Kile BT, Hii LL, O'Dowd RA, Hudson DF, Saffery R, Kalitsis P, Earle E, Choo KH. 1999. Defective chromosome segregation, microtubule bundling and nuclear bridging in inner centromere protein gene (Incenp)-disrupted mice. Hum Mol Genet. 8:1145-55.

Cvetkovic B, Yang B, Williamson RA, Sigmund CD. 2000. Appropriate tissue- and cell-specific expression of a single copy human angiotensinogen transgene specifically targeted upstream of the HPRT locus by homologous recombination. J Biol Chem. 275:1073-8.

Czauderna F, Santel A, Hinz M, Fechtner M, Durieux B, Fisch G, Leenders F, Arnold W, Giese K, Klippel A, Kaufmann J. 2003. Inducible shRNA expression for application in a prostate cancer mouse model. Nucleic Acids Res. 31:e127.

Dagert M, Ehrlich SD. 1979. Prolonged incubation in calcium chloride improves the competence of Escherichia coli cells. Gene. 6:23-8.

Danielian PS, Muccino D, Rowitch DH, Michael SK, McMahon AP. 1998. Modification of gene activity in mouse embryos in utero by a tamoxifen-inducible form of Cre recombinase. Curr Biol. 8:1323-1326.

Davis L, Engebrecht J. 1998. Yeast dom34 mutants are defective in multiple developmental pathways and exhibit decreased levels of polyribosomes. Genetics. 149:45-56.

Delhanty JD, Harper JC, Ao A, Handyside AH, Winston RM. 1997. Multicolour FISH detects frequent chromosomal mosaicism and chaotic division in normal preimplantation embryos from fertile patients. Hum Genet. 99:755-60.

Denarier E, Forghani R, Farhadi HF, Dib S, Dionne N, Friedman HC, Lepage P, Hudson TJ, Drouin R, Peterson A. 2005. Functional organization of a Schwann cell enhancer. J Neurosci. 25:11210-7.

Denhardt DT. 1966. A membrane-filter technique for the detection of complementary DNA. Biochem Biophys Res Commun. 13:641-6.

Dickins RA, Hemann MT, Zilfou JT, Simpson DR, Ibarra I, Hannon GJ, Lowe SW. 2005. Probing tumor phenotypes using stable and regulated synthetic microRNA precursors. Nat Genet. 37:1289-95.

Dooley TP, Miranda M, Jones NC, DePamphilis ML. 1989. Transactivation of the adenovirus EIIa promoter in the absence of adenovirus E1A protein is restricted to mouse oocytes and preimplantation embryos. Development. 107:945-56.

Eberhart CG, Wasserman SA. 1995. The pelota locus encodes a protein required for meiotic cell division: an analysis of $\mathrm{G} 2 / \mathrm{M}$ arrest in Drosophila spermatogenesis. Development. 121:3477-86. 
Elbashir SM, Lendeckel W, Tuschl T. 2001. RNA interference is mediated by 21- and 22-nucleotide RNAs. Genes Dev. 15:188-200.

Engebrecht J, Masse S, Davis L, Rose K, Kessel T. 1998. Yeast meiotic mutants proficient for the induction of ectopic recombination. Genetics. 148:581-98.

Evans MJ, Kaufman MH. 1981. Establishment in culture of pluripotential cells from mouse embryos. Nature. 292:154-6.

Feil R, Brocard J, Mascrez B, LeMeur M, Metzger D, Chambon P. 1996. Ligandactivated site-specific recombination in mice. Proc Natl Acad Sci U S A. 93:10887-90.

Feinberg AP, Vogelstein B. 1984. "A technique for radiolabeling DNA restriction endonuclease fragments to high specific activity". Anal Biochem. 137:266-7.

Fiering S, Epner E, Robinson K, Zhuang Y, Telling A, Hu M, Martin DI, Enver T, Ley TJ, Groudine M. 1995. Targeted deletion of 5'HS2 of the murine beta-globin LCR reveals that it is not essential for proper regulation of the beta-globin locus. Genes Dev. 9:2203-13.

Fire A, Xu S, Montgomery MK, Kostas SA, Driver SE, Mello CC. 1998. Potent and specific genetic interference by double-stranded RNA in Caenorhabditis elegans. Nature. 391:806-11.

Forlino A, Porter FD, Lee EJ, Westphal H, Marini JC. 1999. Use of the Cre/lox recombination system to develop a non-lethal knock-in murine model for osteogenesis imperfecta with an alpha1(I) G349C substitution. Variability in phenotype in BrtlIV mice. J Biol Chem. 274:37923-31.

Frolova L, Le Goff X, Rasmussen HH, Cheperegin S, Drugeon G, Kress M, Arman I, Haenni AL, Celis JE, Philippe M. 1994. A highly conserved eukaryotic protein family possessing properties of polypeptide chain release factor. Nature. 372:701-3.

Fuhrmann-Benzakein E, Garcia-Gabay I, Pepper MS, Vassalli JD, Herrera PL. 2000. unducible and irreversible control of gene expression using a single transgene. Nucleic Acids Res. 28:E99.

Garrick D, Fiering S, Martin DI, Whitelaw E. 1998. Repeat-induced gene silencing in mammals. Nat Genet. 18:56-9.

Gershoni JM, Palade GE. 1982. Electrophoretic transfer of proteins from sodium dodecyl sulfate-polyacrylamide gels to a positively charged membrane filter. Anal Biochem. 124:396-405.

Gil J, Esteban M. 2000. Induction of apoptosis by the dsRNA-dependent protein kinase (PKR): mechanism of action. Apoptosis. 5:107-114.

Hartwell LH, Weinert TA. 1989. Checkpoints: controls that ensure the order of cell cycle events. Science. 246:629-635. 
Henikoff S. 1998. Conspiracy of silence among repeated transgenes. Bioessays. 20:5325.

Hodge R. 1994. Preparation of RNA gel blots. Methods Mol Biol. 28:49-54.

Hogan BL, Blessing M, Winnier GE, Suzuki N, Jones CM. 1994. Growth factors in development: the role of TGF-beta related polypeptide signalling molecules in embryogenesis. Dev Suppl. 53-60.

Holzenberger M, Lenzner C, Leneuve P, Zaoui R, Hamard G, Vaulont S, Bouc YL. 2000. Cre-mediated germline mosaicism: a method allowing rapid generation of several alleles of a target gene. Nucleic Acids Res. 28:E92.

Hu G. 1993. DNA polymerase-catalyzed addition of nontemplated extra nucleotides to the 3' end of a DNA fragment. DNA Cell Biol. 12:763-70.

Huh WK, Falvo JV, Gerke LC, Carroll AS, Howson RW, Weissman JS, O'Shea EK. 2003. Global analysis of protein localization in budding yeast. Nature. 425:686-91.

Hutvagner G, Zamore PD. 2002. A microRNA in a multiple-turnover RNAi enzyme complex. Science. 20:2056-60.

Jackson AL, Bartz SR, Schelter J, Kobayashi SV, Burchard J, Mao M, Li B, Cavet G, Linsley PS. 2003. Expression profiling reveals off-target gene regulation by RNAi. Nat Biotechnol. 21:635-7.

Jonkers J, Berns A. 2002. Conditional mouse models of sporadic cancer. Nat Rev Cancer. 2:251-65.

Kawamoto S, Niwa H, Tashiro F, Sano S, Kondoh G, Takeda J, Tabayashi K, Miyazaki J. 2000. A novel reporter mouse strain that expresses enhanced green fluorescent protein upon Cre-mediated recombination. FEBS Lett. 470:263-8.

Kellendonk C, Tronche F, Monaghan AP, Angrand PO, Stewart F, Schutz G. 1996. Regulation of Cre recombinase activity by the synthetic steroid RU 486. Nucleic Acids Res. 24:1404-11.

Kellendonk C, Tronche F, Casanova E, Anlag K, Opherk C, Schutz G. 1999. Inducible site-specific recombination in the brain. J Mol Bio. 285:175-82.

Khvorova A, Reynolds A, Jayasena SD. 2003. Functional siRNAs and miRNAs exhibit strand bias. Cell. 115:209-16.

Kmita M, Kondo T, Duboule D. 2000. Targeted inversion of a polar silencer within the HoxD complex re-allocates domains of enhancer sharing. Nat Genet. 26:451-4.

Kurreck J. 2006. siRNA Efficiency: Structure or Sequence-That Is the Question. $J$ Biomed Biotechnol. 4:83757. 
Kuzin II, Snyder JE, Ugine GD, Wu D, Lee S, Bushnell T Jr, Insel RA, Young FM, Bottaro A. 2001. Tetracyclines inhibit activated B cell function. Int Immunol. 13:92131 .

Laemmli UK. 1970. Cleavage of structural proteins during the assembly of the head of bacteriophage T4. Nature. 227:680-5.

Laird PW, Zijderveld A, Linders K, Rudnicki MA, Jaenisch R, Berns A. 1991. Simplified mammalian DNA isolation procedure. Nucleic Acids Res. 19:4293.

Lakso M, Pichel JG, Gorman JR, Sauer B, Okamoto Y, Lee E, Alt FW, Westphal H. 1996. Efficient in vivo manipulation of mouse genomic sequences at the zygote stage. Proc Natl Acad Sci U S A. 11:5860-5.

Lightfoot DA, Kouznetsova A, Mahdy E, Wilbertz J, Hoog C. 2006. The fate of mosaic aneuploid embryos during mouse development. Dev Biol. 289:384-94.

Lin H. 2002. The stem-cell niche theory: lessons from flies. Nat Rev Genet. 3:931-40.

Lin Q, Dong C, Cooper MD. 1998. Impairment of T and B cell development by treatment with a type I interferon. J Exp Med. 187:79-87.

Lin YZ, Yao SY, Veach RA, Torgerson TR, Hawiger J. 1995. Inhibition of nuclear translocation of transcription factor NF-kappa B by a synthetic peptide containing a cell membrane-permeable motif and nuclear localization sequence. J Biol Chem. 270:142558 .

Liu JL, Yakar S, LeRoith D. 2000. Conditional knockout of mouse insulin-like growth factor-1 gene using the Cre/loxP system. Proc Soc Exp Biol Med. 223:344-51.

Loonstra A, Vooijs M, Beverloo HB, Allak BA, van Drunen E, Kanaar R, Berns A, Jonkers J. 2001. Growth inhibition and DNA damage induced by Cre recombinase in mammalian cells. Proc Natl Acad Sci U S A. 98:9209-14.

Luo KQ, Chang DC. 2004. The gene-silencing efficiency of siRNA is strongly dependent on the local structure of mRNA at the targeted region. Biochemical and Biophysical Research Communications. 318:303-310.

Martin GR. 1981. Isolation of a pluripotent cell line from early mouse embryos cultured in medium conditioned by teratocarcinoma stem cells. Proc Natl Acad Sci U S A. 78:7634-8.

Martineau SN, Andreassen PR, Margolis RL. 1995. Delay of HeLa cell cleavage into interphase using dihydrocytochalasin B: retention of a postmitotic spindle and telophase disc correlates with synchronous cleavage recovery. J Cell Biol. 131:191-205. 
McDevitt MA, Shivdasani RA, Fujiwara Y, Yang H, Orkin SH. 1997. A "knockdown" mutation created by cis-element gene targeting reveals the dependence of erythroid cell maturation on the level of transcription factor GATA-1. Proc Natl Acad Sci U S A. 94:6781-5.

McManus MT, Haines BB, Dillon CP, Whitehurst CE, van Parijs L, Chen J, Sharp PA. 2002. Small interfering RNA-mediated gene silencing in T lymphocytes. J Immunol. 169:5754-60.

Metzger D, Clifford J, Chiba H, Chambon P. 1995. Conditional site-specific recombination in mammalian cells using a ligand-dependent chimeric Cre recombinase. Proc Natl Acad Sci U S A. 92:6991-6995.

Metzger D, Chambon P. 2001. Site- and time-specific gene targeting in the mouse. Methods. 24:71-80.

Meyers EN, Lewandoski M, Martin GR. 1998. An Fgf8 mutant allelic series generated by Cre- and Flp-mediated recombination. Nat Genet. 18:136-41.

Minamino T, Gaussin V, DeMayo FJ, Schneider MD. 2001. Inducible gene targeting in postnatal myocardium by cardiac-specific expression of a hormone-activated Cre fusion protein. Circ Res. 88:587-92.

Mizushima S, Nagata S. 1990. pEF-BOS, a powerful mammalian expression vector. Nucleic Acids Res. 18:5322.

Moutier R, Toyama K, Cotton WR, Gaines JF. 1976. Three recessive genes for congenital osteopetrosis in Norway rat. J Hered. 67:189-90.

Munne S, Bahce M, Sandalinas M, Escudero T, Marquez C, Velilla E, Colls P, Oter M, Alikani M, Cohen J. 2004. Differences in chromosome susceptibility to aneuploidy and survival to first trimester. Reprod Biomed Online. 8:81-90.

Nair R, Carter P, Rost B. 2003. NLSdb: database of nuclear localization signals. Nucleic Acids Res. 31:397-9.

Nagy E, Mandi Y, Szoke I, Kocsis B. 1998. Induction of Release of Tumor Necrosis Factor and IL-6 from Human Mononuclear Cells by Bacteroides strains. Anaerobe. 4:133-8.

Nilsen TW, Maroney PA, Baglioni C. 1982. Inhibition of protein synthesis in retrovirus-infected HeLa cells with elevated levels of interferon-induced protein kinase activity. Journal of Biological Chemistry. 257:14593-14596.

Novak A, Guo C, Yang W, Nagy A, Lobe CG. 2000. Z/EG, a double reporter mouse line that expresses enhanced green fluorescent protein upon Cre-mediated excision. Genesis. 28:147-55. 
Paddison PJ, Caudy AA, Bernstein E, Hannon GJ, Conklin DS. 2002. Short hairpin RNAs (shRNAs) induce sequence-specific silencing in mammalian cells. Genes Dev. 16:948-58.

Paul CP, Good PD, Winer I, Engelke DR. 2002. Effective expression of small interfering RNA in human cells. Nat Biotechnol. 20:505-8.

Pihan, GA, Doxsey SJ. 1999. The mitotic machinery as a source of genetic instability in cancer. Semin Cancer Biol. 9:289-302

Prochiantz A. 2000. Messenger proteins: homeoproteins, TAT and others. Curr Opin Cell Biol. 12:400-6.

Ragan MA, Logsdon JM Jr, Sensen CW, Charlebois RL, Doolittle WF. 1996. An archaebacterial homolog of pelota, a meiotic cell division protein in eukaryotes. FEMS Microbiol Lett. 144:151-5.

Rasnick D, Duesberg PH. 1999. How aneuploidy affects metabolic control and causes cancer. Biochem J. 340:621-630

Reynolds A, Leake D, Boese Q, Scaringe S, Marshall WS, Khvorova A. 2004. Rational siRNA design for RNA interference. Nature Biotechnology. 22:326-330.

Robinson GW, Wray S, Mahon KA. 1991. Spatially restricted expression of a member of a new family of murine Distal-less homeobox genes in the developing forebrain. New Biol. 3:1183-94.

de Rooij DG, de Boer P. 2003. Specific arrests of spermatogenesis in genetically modified and mutant mice. Cytogenet Genome Res. 103:267-76.

Saiki RK, Gelfand DH, Stoffel S, Scharf SJ, Higuchi R, Horn GT, Mullis KB, Erlich HA. 1988. Primer-directed enzymatic amplification of DNA with a thermostable DNA polymerase. Science. 239:487-91.

Sambrook J, Fritsch EF, Maniatis T. 1989. Molecular cloning: a laboratory manual (2nd edition). Cold Spring Habour, New York, USA.

Sandalinas M, Sadowy S, Alikani M, Calderon G, Cohen J, Munne S. 2001. Developmental ability of chromosomally abnormal human embryos to develop to the blastocyst stage. Hum Reprod. 16:1954-8.

Sanger F, Nicklen S, Coulson AR. 1977. DNA sequencing with chain-terminating inhibitors. Proc Natl Acad Sci U S A. 74:5463-7.

Sauer B, Henderson N. 1988. Site-specific DNA recombination in mammalian cells by the Cre recombinase of bacteriophage P1. Proc Natl Acad Sci U S A. 85:5166-70.

Sauer B. 1993. Manipulation of transgenes by site-specific recombination: use of Cre recombinase. Methods Enzymol. 225:890-900. 
Schaefer BC, Schaefer ML, Kappler JW, Marrack P, Kedl RM. 2001. Observation of antigen-dependent CD8+ T-cell/ dendritic cell interactions in vivo. Cell Immunol. 214:110-22.

Schmidt EE, Taylor DS, Prigge JR, Barnett S, Capecchi MR. 2000. Illegitimate Credependent chromosome rearrangements in transgenic mouse spermatids. Proc Natl Acad Sci U S A. 97:13702-7.

Schubert S, Grünweller A, Erdmann VA, Kurreck J. 2005. Local RNA target structure influences siRNA efficacy: systematic analysis of intentionally designed binding regions. Journal of Molecular Biology. 348:883-893.

Schwarz DS, Hutvágner G, Du T, Xu Z, Aronin N, Zamore PD. 2003. Asymmetry in the assembly of the RNAi enzyme complex. Cell. 115:199-208.

Schwenk F, Baron U, Rajewsky K. 1995. A cre-transgenic mouse strain for the ubiquitous deletion of loxP-flanked gene segments including deletion in germ cells. Nucleic Acids Res. 23:5080-1.

Schwenk F, Kuhn R, Angrand PO, Rajewsky K, Stewart AF. 1998. Temporally and spatially regulated somatic mutagenesis in mice. Nucleic Acids Res. 26:1427-1432.

Selbert S, Bentley DJ, Melton DW, Rannie D, Lourenco P, Watson CJ, Clarke AR. 1998. Efficient BLG-Cre mediated gene deletion in the mammary gland. Transgenic Res. 7:387-96.

Shamsadin R, Adham IM, von Beust G, Engel W. 2000. Molecular cloning, expression and chromosome location of the human pelota gene PELO. Cytogenet Cell Genet. 90:75-8.

Shamsadin R, Adham IM, Engel W. 2002. Mouse pelota gene (Pelo): cDNA cloning, genomic structure, and chromosomal localization. Cytogenet Genome Res. 97:95-9.

Sharp PA. 2001. RNA interference--2001. Genes Dev. 15:485-90.

Silver DP, Livingston DM. 2001. Self-excising retroviral vectors encoding the Cre recombinase overcome Cre-mediated cellular toxicity. Mol Cell. 8:233-43.

Snow, M.H.L. 1977. Gastrulation in the mouse: growth and regionalisation of the epiblast. J Embryol Exp Morphol. 42:293-303.

Song X, Wong MD, Kawase E, Xi R, Ding B.C, McCarthy J.J, Xie T. 2004. Bmp signals from niche cells directly repress transcription of a differentiation-promoting gene, bag of marbles, in germline stem cells in the Drosophila ovary. Development. 131:1353-1364.

Soriano P. 1999. Generalized lacZ expression with the ROSA26 Cre reporter strain. Nat Genet. 21:70-1. 
Southern EM. 1975. Detection of specific sequences among DNA fragments separated by gel electrophoresis. J Mol Biol. 98:503-17.

Sui G, Soohoo C, Affar el B, Gay F, Shi Y, Forrester WC, Shi Y. 2002. A DNA vectorbased RNAi technology to suppress gene expression in mammalian cells. Proc Natl Acad Sci U S A. 99:5515-20.

Thyagarajan B, Guimaraes MJ, Groth AC, Calos MP. 2000. Mammalian genomes contain active recombinase recognition sites. Gene. 244:47-54.

Thomas KR, Capecchi MR. 1987. Site-directed mutagenesis by gene targeting in mouse embryo-derived stem cells. Cell. 51:503-512.

Torres RM, Kühn R. 1997. Laboratory Protocols for Conditional Gene Targeting. Oxford Univ. Press.

Tronche F, Kellendonk C, Kretz O, Gass P, Anlag K, Orban PC, Bock R, Klein R, Schutz G. 1999. Disruption of the glucocorticoid receptor gene in the nervous system results in reduced anxiety. Nat Genet. 23:99-103.

Tuschl T, Zamore PD, Lehmann R, Bartel DP, Sharp PA. 1999. Targeted mRNA degradation by double-stranded RNA in vitro. Genes Dev. 13:3191-7.

Uetsuki T, Naito A, Nagata S, Kaziro Y. 1989. Isolation and characterization of the human chromosomal gene for polypeptide chain elongation factor-1 alpha. Biol Chem. 264:5791-8.

Uren AG, Wong L, Pakusch M, Fowler KJ, Burrows FJ, Vaux DL, Choo KH. 2000. Survivin and the inner centromere protein INCENP show similar cell-cycle localization and gene knockout phenotype. Curr Biol. 10:1319-28.

van de Wetering M, Oving I, Muncan V, Pon Fong MT, Brantjes H, van Leenen D, Holstege FC, Brummelkamp TR, Agami R, Clevers H. 2003. Specific inhibition of gene expression using a stably integrated, inducible small-interfering-RNA vector. $E M B O$ Rep. 4: 609-15.

Vasioukhin V, Degenstein L, Wise B, Fuchs E. 1999. The magical touch: genome targeting in epidermal stem cells induced by tamoxifen application to mouse skin. Proc. Natl Acad Sci U S A. 96:8551-8556.

Visscher DW, Micale MA, Crissman JD. 1993. Pathological and biological relevance of cytophotometric DNA content to breast carcinoma genetic progression. J. Cell Biochem Suppl. 17:114-122

Vooijs M, Jonkers J, Berns A. 2001. A highly efficient ligand-regulated Cre recombinase mouse line shows that LoxP recombination is position dependent. $E M B O$ Rep. 2:292-7. 
Xi R, Doan C, Liu D, Xie T. 2005. Pelota controls self-renewal of germline stem cells by repressing a Bam-independent differentiation pathway. Development. 132:5365-74.

Xie T, Spradling AC. 1998. Decapentaplegic is essential for the maintenance and division of germline stem cells in the Drosophila ovary. Cell. 94:251-60.

Xu X, Weaver Z, Linke SP, Li C, Gotay J, Wang XW, Harris CC, Ried T, Deng CX. 1999. Centrosome amplification and a defective G2-M cell cycle checkpoint induce genetics instability in BRCA1 exon 11 isoform-deficient cells. Mol Cell. 3:389-395.

Yarranton GT. 1992. Inducible vectors for expression in mammalian cells. Curr Opin Biotechnol. 3:506-511.

Yang D, Buchholz F, Huang Z, Goga A, Chen CY, Brodsky FM, Bishop JM. 2002. Short RNA duplexes produced by hydrolysis with Escherichia coli RNase III mediate effective RNA interference in mammalian cells. Proc Natl Acad Sci U S A. 99:9942-7.

Yu JY, DeRuiter SL, Turner DL. 2002. RNA interference by expression of shortinterfering RNAs and hairpin RNAs in mammalian cells. Proc Natl Acad Sci US A. 99:6047-52.

Zimmermann S, Steding G, Emmen JM, Brinkmann AO, Nayernia K, Holstein AF, Engel W, Adham IM. 1999. Targeted disruption of the Insl3 gene causes bilateral cryptorchidism. Mol Endocrino. 13:681-91. 


\section{ACKNOWLEDGEMENTS}

This is perhaps the easiest and hardest chapter that I have to write. It will be simple to name all the people that helped to get this done, but it will be tough to thank them enough. I will nonetheless try...

First and foremost, I would like to express my honest gratitude to Prof. Dr. W.Engel for giving me the chance to perform my Ph.D. study under his supervision, creating diverse cultural environment of researchers and students, and providing such a stimulating and enjoyable scientific atmosphere at the Institute of Human Genetics, Göttingen. His capacity to combine critique with an immediate empathy and commitment towards students and workers engaged in struggle will always inspire me. Special thanks that he spent a lot of his time on proofreading of my thesis very carefully and seriously.

My particular gratitude goes to my supervisor Prof. Dr. I.M.Adham for his helpful support during the whole time of this study. He was also a particular good leader and hard-working guy, enabling his team to face the hard work. I have also to thank to him for guiding me through the writing of the thesis, and for all the corrections and revisions made to text that is about to be read. It became a lighter and more concise thesis after his preferment.

I sincerely thank PD Dr. S.Hoyer-Fender to be my co-referee. I also extend my sincere thanks to Prof. Dr. M.Mühlenberg and PD Dr. M.Hauck for accepting to be my examiners and Prof. Dr. G.Braus and Prof. Dr. I.Feußner for accepting to be committee members for managing to read the whole thesis so thoroughly, despite having a very busy schedule.

I am grateful to the secretary Ms. P.Albers at the Institute of Human Genetics for being always friendly and assisting me in many different ways.

I would like to thank the German Research Foundation (DFG), not only for providing financial support which allowed me to undertake this research, but also for giving me the opportunity to attend conferences and learn so many interesting people.

I would like to thank to Mongolian Academy of Sciences for giving me a great chance to study for PhD in Germany and my supervisor Prof. Dr. Kh.Tumennasan in the Institute of Biology, Mongolia who stimulated me to develop my career. 
All my current and former colleagues and friends (you all know who is included) in the Institute of Human Genetics are, without a doubt, one of the finest group of people I have ever had for providing a such good working atmosphere and for helping me whenever I needed assistance, in which to learn and grow. I wish to single out for special consideration Katy, Ilona, Wolfgang, Oggie, Torsten, Nadine, Christian, Arvind, Jessica, Nadya, Sandra, Harald, Moneef, Tanasis, Tseku, Krishna, Tomoko, Steffi, Nadine and Jan for their encouragement, continued moral support, humor (sometimes ironic) and friendship.

Most especially, let me thank one of my best friends, Susan, who was my neighbour in the beginning of our study for her kindness, support, care, friendship and for supplying me with encouragement when I needed it over these past years.

To Sissi and Martina, and their family, I wish to extend my most heart felt thanks and appreciation for being my family, sisters and friends, welcoming me into your home and giving me additional possibilities to integrate to German life and culture. I am very happy that I learned them and indebted to them for their help.

I am grateful to my Mongolian friends in Germany who over several years have welcomed me into their homes sharing our homesickness and gathering together routinely. That was always fun. In addition, the warm support of all my friends in Mongolia supported me in many different ways to have a wonderful time along the way. I wish I could mention each individually, but will throw a large party instead.

Last, but definitely not least, I want to express my deep appreciation and love for my family and relatives. Whatever I have or will achieve in this life will be as a direct result of the love and the faith they have given to me. I dedicate this dissertation to my parents, and in particular, to the memory of my Dad who was provided me with an early appreciation taking step to the science.

Finally, this work would not have been possible without the excellent support of all mentioned people.

Thank you very much for all,

Danke schön für alle, 


\section{CURRICULUM VITAE}

\section{Personal Data:}

Full Name: Byambajav Buyandelger

E-mail: bbuyand@gwdg.de; byambaa2000@hotmail.com

Date of Birth: 3d, April, 1976

Sex: Female

Present Address: Robert-Koch Str 8, D-37075, Goettingen, Germany

Nationality: Mongolian

Marital Status: Single

\section{Educational Background:}

Oct, 2003 - Dec, 2006

Oct, 2001 - Feb, 2003

Sep, 1993 - Jan, 1998
PhD study, Institute of Human Genetics, Georg-August University, Goettingen, Germany

Title of thesis: "Expression and functional analyses of murine Pelota (Pelo) gene"

Master of Science, Faculty of Biology, National University of Mongolia, Ulaanbaatar, Mongolia

Bachelor of Science, Faculty of Biology, National University of Mongolia, Ulaanbaatar, Mongolia 